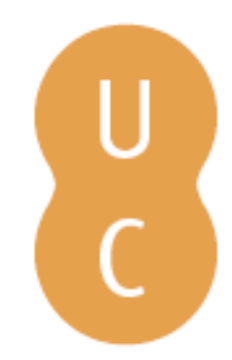

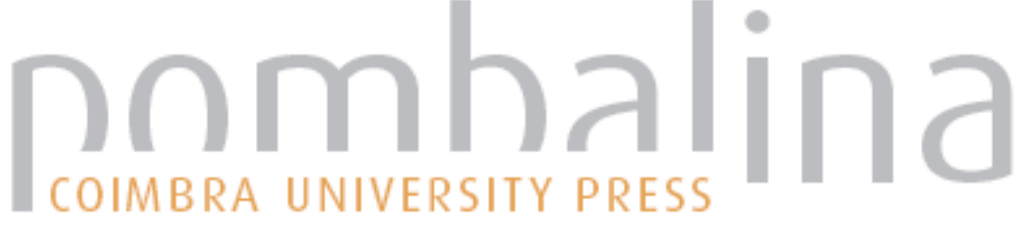

\section{Contra Neera [Demóstenes] 59}
Autor(es):
Apolodoro
Publicado por: Imprensa da Universidade de Coimbra
URL
persistente:
URI:http://hdl.handle.net/10316.2/2404
DOI:
DOI:http://dx.doi.org/10.14195/978-989-26-0777-1

Accessed : $\quad$ 26-Apr-2023 11:14:46

A navegação consulta e descarregamento dos títulos inseridos nas Bibliotecas Digitais UC Digitalis, UC Pombalina e UC Impactum, pressupõem a aceitação plena e sem reservas dos Termos e Condições de Uso destas Bibliotecas Digitais, disponíveis em https://digitalis.uc.pt/pt-pt/termos.

Conforme exposto nos referidos Termos e Condições de Uso, o descarregamento de títulos de acesso restrito requer uma licença válida de autorização devendo o utilizador aceder ao(s) documento(s) a partir de um endereço de IP da instituição detentora da supramencionada licença.

Ao utilizador é apenas permitido o descarregamento para uso pessoal, pelo que o emprego do(s) título(s) descarregado(s) para outro fim, designadamente comercial, carece de autorização do respetivo autor ou editor da obra.

Na medida em que todas as obras da UC Digitalis se encontram protegidas pelo Código do Direito de Autor e Direitos Conexos e demais legislação aplicável, toda a cópia, parcial ou total, deste documento, nos casos em que é legalmente admitida, deverá conter ou fazer-se acompanhar por este aviso.

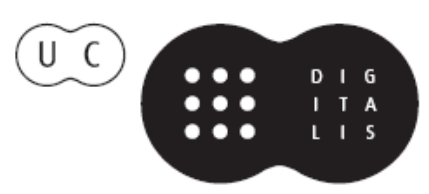




\section{Apolodoro}

\section{Contra NeEra [Demóstenes] 59}

TRADUÇÃO DO GREGO Glória ONELley INTRODUÇÃO, NOTAS E ÍNDICE Ana lúcia Curado 
(Página deixada propositadamente em branco) 


\section{[Demóstenes]}

\section{Contra Neera}

Tradução do grego de

Glória Onelley

Universidade Federal Fluminense

INTRODUÇÃO, NOTAS E ÍNDICE DE Ana Lúcia Curado

Universidade do Minho

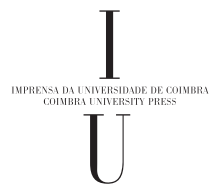


TODOS OS VOLUMES DESTA SÉRIE SÃO SUJEITOS A ARBITRAGEM CIENTÍ́fICA INDEPENDENTE.

Título • Contra Neera. [Demóstenes] 59.

Tradução do grego: Glória Onelley.

Introduçâo, notas e índice: Ana Lúcia Curado

Autor - Apolodoro

Série Autores Gregos e Latinos - Textos

Coordenador Científico do plano de edição: Maria do Céu Fialho

\section{Conselho Editorial}

José Ribeiro Ferreira

Francisco de Oliveira

Maria de Fátima Silva

Nair Castro Soares

Director Técnico: Delfim Leăo

\section{Obra realizada no Âmbito das actividades da UI\&D \\ Centro de Estudos Clássicos e Humanísticos}

\section{EdiçÃo}

Imprensa da Universidade de Coimbra

URL: http://www.uc.pt/imprensa_uc

E-mail: imprensauc@ci.uc.pt

Vendas online:

http://livrariadaimprensa.uc.pt

Impressão e ACABAmento

Simóes \& Linhares

ISBN

978-989-26-0515-9

\section{COORdENAÇÃo EDITORIAL}

Imprensa da Universidade de Coimbra

Concepção gráfica \& Paginação

Rodolfo Lopes \& Nelson Henrique

Pré-IMPRESSÃo

Imprensa da Universidade de Coimbra

1 ${ }^{\text {a }}$ EDIÇÃo: CECH • 2011

2a EDIÇÃO: IUC • 2012

3a Ediçấ: IUC・ 2013

\section{ISBN DigitaL}

978-989-26-0777-1

\section{DOI}

http://dx.doi.org/

10.14195/978-989-26-0777-1

\section{Depósito Legal}

$358459 / 13$

(C) Abril 2013.

IMPRENSA DA UNIVERSIDADE DE COIMBRA

Classica Digitalia Vniversitatis Conimbrigensis (http://classicadigitalia.uc.pt) Centro de Estudos Clássicos e Humanísticos da Universidade de Coimbra

Reservados todos os direitos. Nos termos legais fica expressamente proibida a reprodução total ou parcial por qualquer meio, em papel ou em edição electrónica, sem autorizaçâo expressa dos titulares dos direitos. É desde já excepcionada a utilizaçáo em circuitos académicos fechados para apoio a leccionação ou extensão cultural por via de e-learning. 


\section{ÍNDICE}

$\begin{array}{ll}\text { Nota PrÉVIa } & 7\end{array}$

INTRODUÇĀO

Autenticidade do Discurso 9

Contexto Cronológico 12

Mulheres Legítimas, Heteras, Prostitutas e Concubinas 14

HistóRIaS da VIDA Privada 28

ApresentaÇÃo do Discurso 66

Procedimento Judicial $\quad 67$

Do Discurso ao Veredito $\quad 71$

$\begin{array}{ll}\text { CONTRA NEERA } & 73\end{array}$

$\begin{array}{ll}\text { BibLIOGRAFIA } & 131\end{array}$

$\begin{array}{ll}\text { ÍNDICE DE NOMES } & 137\end{array}$ 
(Página deixada propositadamente em branco) 


\section{Nota Prévia}

O discurso Contra Neera atribuído a Apolodoro, que integra o Corpus Demosthenicum, apresenta um retrato muito vivo da vida quotidiana do século IV a. C. da cosmopolita cidade de Atenas, capital dos grandes Oradores Áticos. Este discurso da vida privada permite espreitar os bastidores da vida íntima de uma cortesã e do seu esforço para tentar sobreviver numa sociedade confinada por regras e por limites difíceis de transpor. A cidade de Atenas dos séculos V e IV a.C. permitia comportamentos extrovertidos, ao mesmo tempo que mantinha um corpo legal preparado para zelar pelo bem-estar de homens ou mulheres que viviam na polis. Neera, a sua família e o seu companheiro Estéfano atraem olhares que criticam o seu modo de vida, os seus comportamentos, as suas companhias e o aparente despudor das suas atitudes.

Náo parece justo ao orador deste discurso que se aplauda a vida de uma hetera, ou cortesã, ou se faça silêncio sobre o seu modo de viver, ou simplesmente saia 
impune dos crimes de que é acusada. É destas histórias e das suas entrelinhas que trata o discurso Contra Neera.

A tradução feita pela Doutora Glória Braga Onelley baseia-se na edição de W. Rennie (Demosthenis Orationes, III, Oxonii, 1931, reimp. 1991). As ediçóes de C. Carey (1992) e de K. Kapparis (1999) foram seguidas de perto para a introdução e notas a esta tradução.

Quanto aos títulos das obras citadas de autores gregos procura-se adoptar, sempre que seja possível, as abreviaturas do dicionário de Liddell e Scott (Greek-English Lexicon).

Cumpre-nos agradecer aos Senhores Doutores Francisco de Oliveira e Delfim Leão a confiança que em nós depositaram para a realização deste trabalho académico.

Ana Lúcia Curado e Glória Onelley 


\section{INTRODUÇÃO}

\section{Autenticidade do Discurso}

No Corpus Demosthenicum há discursos cuja autenticidade tem suscitado dúvidas desde a Antiguidade. O debate mantém-se longo. Alguns discursos são atribuídos a Apolodoro ou a um logógrafo desconhecido. ${ }^{1}$ Em alguns casos esse autor confunde-se, assemelha-se e é diferente do grande orador Demóstenes, seu contemporâneo. Apolodoro (c. 394 - depois de 343 a.C.) é considerado um orador de menor dimensão e propriedade em relação ao testemunho conhecido pelo grupo canónico dos Oradores Áticos,

Sem querer emendar o cânone alexandrino com o número do elenco referido, poderia seguir-se a lição de Lionel Pearson quando intitula um dos seus artigos "Apolodoro, o décimo primeiro orador ático". ${ }^{2}$ Assim, segundo alguns estudiosos do século XX, a diferença entre Demóstenes e Apolodoro assenta basicamente no estilo da escrita, na abundância e no pormenor da informação disponibilizada. No entanto, estes autores baseiam-se nas mesmas disposiçóes legais, obedecem aos mesmos padróes de trabalho jurídico nos tribunais e retratam a mesma realidade social.

${ }^{1}$ Ainda sobre esta matéria vide Cortés Gabaudán (1986: 349-355).

${ }^{2}$ Pearson (1966: 347-359). 
Desde os famosos estudos de Schaefer e Blass, no século XIX, que a questão tem sido discutida mais recentemente por numerosos autores, nomeadamente Cortés Gabaudán, Carey, Trevett e Kapparis. Existe um grupo de discursos dentro do Corpus Demosthenicum (46, $47,49,50,52,53,59)$, compreendidos cronologicamente entre 369 e 341 a.C., que demonstram um caráter apócrifo devido a características linguísticas e estilísticas. Para Kapparis, este grupo de sete discursos foi escrito "pela mesma mão, porque eles são muito similares na linguagem, estilo e técnica." ${ }^{3}$ No entanto, como afirma Carey, as conclusóes mantêm-se extremamente subjetivas. ${ }^{4}$ Para Trevett, essa subjetividade tem-se vindo a desvanecer com a aplicação de técnicas estatísticas. ${ }^{5} \mathrm{Um}$ dos discursos do Corpus Demosthenicum a respeito do qual se coloca a questão da autenticidade é precisamente o Contra Neera.

A questão da autenticidade de Contra Neera, que foi posta em causa desde muito cedo pela crítica textual, começou por ser formulada na Antiguidade por Dionísio de Halicarnasso (D. H. Dem. 57.2-3), que pôe em dúvida a autoria que Calímaco tinha incluído nas suas Pinakes, ao rejeitar claramente este discurso. Dionísio de Halicarnasso fez uma apreciação sobre as qualidades estilísticas típicas dos textos de Demóstenes que conhecia. Chega mesmo a contabilizar a extensão desse corpus textual em cerca de cinquenta ou sessenta mil linhas. Como nesse corpus não se encontram

\footnotetext{
${ }^{3}$ Kapparis (1999: 50).

${ }^{4}$ Carey (1992: 17).

${ }^{5}$ Trevett (1992: 62-70).
} 
construçóes estilísticas despojadas de elegância, vulgares e grosseiras, Dionísio de Halicarnasso inferiu que os textos onde se encontram construçóes estilísticas com essas propriedades não podem ser atribuídos a Demóstenes, sendo, por conseguinte, apócrifos. Neste conjunto, Dionísio de Halicarnasso (Dem. 57.3) indica ostensivamente cinco textos, um dos quais o Contra Neera:

Ora, se se descobrem algumas construçóes desagradáveis, vulgares e grosseiras, elas encontram-se nos discursos apócrifos, como por exemplo nos dois Contra Aristogiton e até na defesa Contra uma Acusação de Corrupção, no discurso Para não Ceder Hárpalo, no Contra Neera, no discurso Sobre o Tratado com Alexandre, e em muitos outros que Demóstenes não escreveu (é o que eu mostro numa outra obra consagrada a Demóstenes).

Efetivamente, a autoria do Contra Neera tem suscitado alguma polémica. Há os que defendem a sua incorporação simples no Corpus Demosthenicum, sem qualquer outra proposta de solução, como Jaeger, MacDowell, Just e Todd. ${ }^{6}$ Há os que o atribuem diretamente a Apolodoro, embora numericamente figurando no Corpus Demosthenicum, como Macurdy, Kennedy, Lacey, Mossé e Carey. ${ }^{7}$ Há outros ainda

${ }^{6}$ Jaeger (1945: 290-291). MacDowell (1978). Just (1989: 18, 41-42, 52, 62-64, 126-127, 140-143). Todd (1995).

${ }^{7}$ Segundo Kennedy, Apolodoro colaborou com Demóstenes na tentativa de conversão dos fundos do theoricon em fins militares. Kennedy chega mesmo a afirmar que uma das consequências desta colaboraçáo foi a escrita por Demóstenes do primeiro discurso 
que, não querendo participar em polémicas, optam simplesmente por atribuí-lo a um Pseudo-Demóstenes ou a um autor diferente de Demóstenes, como Keuls, Edwards e Cox. ${ }^{8}$

$\mathrm{O}$ status quaestionis contemporâneo confere claramente a Apolodoro o discurso Contra Neera.

\section{Contexto Cronológico}

Para datar este discurso pode recorrer-se a dois passos: os parágrafos 4-8 e o parágrafo 26 . No primeiro descreve-se a tentativa falhada de Apolodoro, cerca de 349 a.C., fazer com que o povo votasse uma proposta de aplicar o dinheiro excedente da administração aos fundos militares ou aos fundos dos espetáculos, istoé, aos theorika; no segundo, faz-se referência ao poeta Xenoclides. Ora no primeiro passo não há qualquer referência a que tenha sido feita efetivamente a transferência dos fundos do theorikon para fins militares, visto que essa medida só terá sido tomada cerca de 339 a. C., por Demóstenes, que renovou o decreto outrora proposto por Apolodoro. Esta referência à transferência dos fundos teria sido utilizada por Teomnesto como forma de vincar que o princípio da proposta de Apolodoro era o de prestar um bom serviço ao bem comum e que ele fora injustamente declarado culpado. Por este fato o discurso deve ter sido pronunciado antes de 339 a.C., terminus ante quem.

Contra Estéfano (1963: 243-249; 1994: 64, 70-71). Ver também Macurdy (1942), Lacey (1968: 112), Mossé (1983: 66; 1994: 87, 89, 152) e Carey (1992: 17; 1997).

${ }^{8}$ Keuls (1993: 156, 418). Edwards (1994: 42). Cox (1998: 183-185). 
No segundo passo, parágrafo 26, Apolodoro refere que o poeta Xenoclides também fora amante de Neera, quando ela trabalhava em Corinto; no entanto, afirma que não o pode chamar a testemunhar porque as leis não o permitiam (cf. [D.] 59.27-28). Xenoclides fora acusado por Estéfano e declarado culpado, em 369 a. C., de astrateia, ação judicial de índole pública por um cidadão não ter participado em campanha militar. Em consequência disso deixou Atenas e estabeleceu-se na Macedónia na corte de Filipe. Em 343 a.C. foi expulso da Macedónia e parece ter regressado a Atenas. ${ }^{9}$ A sua incapacidade para testemunhar resultava da condenação por astrateia, que confirmava a sentença de atimia, pena que correspondia à perda de direitos cívicos, como o direito de se dirigir à boule ou à ecclesia, o direito de processar ou de ser processado nos tribunais, o direito a estar presente em locais sagrados e participar em ritos públicos religiosos. ${ }^{10} \mathrm{~A}$ atimia de Xenoclides parece não ter sido retirada. Esse é de fato o único motivo que faz com que Xenoclides não pudesse testemunhar, porque em 343 a. C., considerado terminus post quem, ele já se encontrava em Atenas, depois de ter sido expulso da Macedónia.

$\mathrm{Na}$ ausência de mais informação e com estes dados disponíveis, a data mais provável em que terá sido pronunciado este discurso localiza-se entre 343 e 339 a.C. ${ }^{11}$

${ }^{9}$ Cf. D. 19.331 e [D.] 59.27.

${ }^{10}$ Harrison (1998 II: 169-176).

${ }^{11}$ Carey (1992: 3) e Kapparis (1999: 1, 28). 


\section{Mulheres Legítimas, Heteras, Prostitutas e Concubinas}

O casamento e a família não esgotavam o universo das relaçóes entre os homens e as mulheres de Atenas. Existem muitas outras figuras femininas no quotidiano do homem socialmente ativo. A rutura da vida familiar ficava completa com o aparecimento de outros desafios que algumas vezes desorganizavam a estrutura dessa vida, mas que possibilitavam a realização de outras necessidades do homem.

É notória a importância da relação que o esposo tem com uma mulher fora do casamento. A mulher estatutariamente legítima constituía um veículo para a legitimação da vida social e pública do homem. Contudo, a mulher legítima não desempenhava outros papéis femininos importantes, como o de parceira amorosa, amiga, confidente e companheira de festas e banquetes. Estes papéis eram elementos fundamentais para que um homem se sentisse particularmente motivado e feliz. O bem-estar de um homem ateniense implicava a existência de outro tipo de mulheres. No entanto, também era possível que um marido desejasse, ao regressar a casa, receber a atenção e as carícias da sua esposa legítima. Isso mesmo é referido por Xenofonte (X. Smp. 9.7). O referido passo, que se encontra já no final do Banquete, revela-se uma apologia do matrimónio regular, pois o autor mostra como os convidados, os que são casados, estão ansiosos por irem para junto das suas mulheres, depois de terem assistido a uma representação de pantomima dos amores de Ariadne e Dioniso. 
Tornou-se famosa a definição de Apolodoro ([D.] 59.122) a propósito das diferenças entre hetaira, pallake e gyne: "com efeito, nós temos as heteras para o prazer, as concubinas para cuidado diário do corpo, e as esposas para gerar filhos legitimamente e ter uma fiel guardiã da nossa casa." Segundo esta definição, a hetaira é a cortesã, à qual o homem solicita prazeres sensuais; a pallake é a concubina que se dedica aos cuidados quotidianos que a vida física exigia; e, por último, a gyne é a esposa e a mãe dos filhos legítimos e é também a guardiã fiel do lar.

A liberdade auferida pelas heteras, prostitutas e concubinas era limitada. Quando se fala de liberdade para estas mulheres, fala-se com o propósito de as comparar às esposas legítimas, jovens e mães de família que viviam circunscritas ao lar e às tarefas inerentes à vida de uma família.

As heteras, prostitutas e concubinas eram concebidas pelo homem como contributo e parte integrante da sua vida social. As citaristas e as heteras aparecem associadas diretamente ao prazer e à vida exterior. A sua presença em festas e banquetes tinha de ser requisitada, pois nem todas elas se revestiam da fama de uma Aspásia. Faziam companhia aos homens e prestavam serviço nos banquetes. Estas participaçóes sociais punham-nas em contato com políticos, filósofos, homens de negócios, artistas e intelectuais de Atenas. Desta forma, este contato enriquecia a sua formação humana, cultural e social. A presença feminina neste tipo de acontecimentos sociais também contribuía com um toque particular de brilho e de elegância. 
Não há indícios seguros para afirmar que, por parte destas mulheres, havia uma autonomia da escolha dos clientes e dos amantes. A supervisão masculina impunha-se quase sempre. Nalguns casos ela atribuía uma segurança particular à vida pública dessas mulheres que, embora não simbolizassem a virtude, também não eram marginais quando observadas pelos seus principais interessados - os homens. A maioria das mulheres gregas tinha um modo de vida silencioso e recluso. As mulheres públicas, que usufruíam de uma liberdade completamente vedada às esposas de cidadãos, viviam com um estatuto à margem da lei. Para a historiadora Claude Mossé, esse era o preço pago em troca da inversão dos valores cívicos, ainda que ao mesmo tempo essas mulheres usufruíssem de liberdade e independência nas palavras e nos comportamentos. ${ }^{12}$

$\mathrm{O}$ inventário das identidades femininas gregas e dos papéis que lhe estão associados permite conhecer os diferentes tipos de mulher ao dispor de um homem comum dos séculos V e IV a.C. e como é que esse homem encara a realidade feminina.

A hetaira é a cortesã com um elevado nível social. $\mathrm{Na}$ tipologia do feminino feita por Apolodoro acontece uma curiosa alteração do papel atribuído à hetaira. Nessa situação específica, o autor da definição pretende-se referir à prostituta em geral. A hetaira estava ligada ao prazer sexual e ao companheirismo de festas e banquetes, embora a sua presença também se caracterizasse pela cultura porque era dotada para as artes da música, canto

${ }^{12}$ Mossé (1983: 76-77). 
e dança, e até mesmo para a leitura de poetas. A hetaira podia exercer a prática do amor de uma forma privada e individual, ou de uma forma pública e profissional. Esta categoria de mulheres parece ter estado vocacionada para proporcionar sedução, paixão, encanto e erotismo.

A pallake possuía um valor e um estatuto intermédio entre a hetera e a esposa legítima. Não se identifica com nenhuma das outras duas, mas tem um pouco de cada uma delas. Não é uma esposa legítima, mas faz as vezes de esposa ao tornar-se a companheira de um homem na sua casa por um longo período de tempo. Ambas têm um local de permanência diária ou habitual que é a casa. A propósito desta ambivalência, veja-se uma breve passagem do discurso de Apolodoro, agora em análise. Antecipando a defesa de Estéfano, o orador está curioso quanto à argumentação da defesa no processo contra Neera. Há certezas incontornáveis a respeito desta mulher, mas existem também algumas questôes interessantes. "Mas tinha sido atestado que ela era cortesã e que fora escrava de Nicareta. Ora ela não é mulher dele, mas ele tem-na como concubina em sua casa?" ([D.] 59.118). Neera fora inicialmente escrava de Nicareta e cedo se tornara cortesã (hetaira). Depois de alguma agitação na sua vida, Neera torna-se amante de Estéfano e com isto enceta um novo percurso da sua existência mais estável e prolongado. Ela passa a ser sua concubina (pallake) e coabita com Estéfano em sua casa, de modo similar a uma esposa, sem no entanto o ser.

A maior semelhança entre a concubina e a esposa legítima reside no fato de os filhos que a primeira der 
ao seu companheiro serem reconhecidos como tal. Esses filhos não têm, porém, o estatuto da legitimidade conferido em exclusivo pelo processo da engyesis e ekdosis ou da epidikasia. A diferença que distingue a esposa legítima da pallake já fora enunciada em [D.] 59.118, onde é reforçada a ideia de que a gyne é a mulher casada solenemente. A natureza feminina da gyne é aproveitada para gerar legitimamente continuadores do oikos e para velar e gerir os bens desse mesmo oikos. Apenas o estatuto conferido pelo casamento permite o desempenho dessas responsabilidades.

A definição mais simples é que a pallake ou concubina era uma mulher que vivia com um homem sem ser a sua esposa. A relação da pallake com o homem da casa caracterizava-se mais pela aceitação social do que pelo seu estatuto legal. A pallake era geralmente uma jovem rapariga livre, mas pobre, ou uma rapariga escrava. O seu baixo estatuto social contribuía para hipotecar o seu futuro. Um homem podia ter uma escrava para ser sua parceira sexual, mesmo que fosse casado, sendo essa escrava uma pallake. Um homem podia coabitar com uma mulher livre numa união informal à semelhança de uma esposa legítima, sendo essa mulher também uma pallake. Por conseguinte, uma pallake era uma amante que mantinha uma relação de maior duração do que a relação do homem com uma hetera ou cortesá. Se uma hetaira passava a coabitar com um homem permanentemente, ela tornava-se entáo uma pallake, sem contudo deixar de ser uma hetaira. Este caso é especialmente bem representado por Neera. A pallake 
estava unida ao seu companheiro sem se proceder a qualquer ato jurídico formal expressamente criado para esse efeito ou sem uma cerimónia que assinalasse o início dessa união. $\mathrm{O}$ concubinato assumia por vezes uma forma clandestina. Em nenhum lugar se encontra o legislador ateniense a defender ou a condenar o sustento de uma pallake e o cuidado para com ela (cf. e.g. Lys. 1.31; Is. 3.17 e 39, 6.18-21). Aliás, um homem de bem, um aner kalos te kai agathos, podia ter uma pallake (Antipho 1.14).

Apesar de as leis de Atenas não condenarem nem defenderem o concubinato, a relação do homem com a sua pallake estava protegida pela lei. Um companheiro que surpreendesse um homem em flagrante delito a ter relaçóes com a sua concubina podia matá-lo, como se fosse o amante da sua esposa legítima (Lys. 1.31; D. 23.53 e 55). Contudo, este tipo de uniáo era tido em menos consideração do que a união instaurada pelo casamento legítimo, ainda que houvesse entre elas um paralelo. $\mathrm{O}$ fato de o caso das concubinas ser mencionado ostensivamente por um enunciado legal (Lys. 1.31; D. 23.53 e 55) mostra o relevo e a aceitação que tais figuras mereciam no seio da sociedade.

Os pais de uma jovem rapariga rica ou pertencente a uma família nobre não permitiam fazer da sua filha uma concubina. Esta uniáo não tinha os mesmos efeitos que um casamento legalmente concebido. Quando uma mulher ateniense era dada como concubina, esse fato correspondia a abdicar do seu estatuto de cidadania. Ora a cidadania para uma mulher consistia na possibilidade 
de ser dada em casamento legal, no direito de dar à luz cidadáos e ainda de participar na vida da comunidade como representante dum oikos ateniense. ${ }^{13}$

Se era unanimemente aceite que os filhos que nasciam de um ateniense e de uma ateniense eram cidadãos, já se nota uma evolução sobre aqueles que descendiam de uma união com uma concubina. Neste caso, os filhos podiam ou não ser cidadãos, visto que eles eram identificados como nothoi e nothai.

Um homem escolhia uma mulher para concubina não para viver maritalmente com ela ou para ter filhos, mas devido a fortes razóes emocionais, ou devido ao prazer derivado da sexualidade. Uma relaçáo com uma concubina revela-se mais física e menos digna do que um casamento, mas parece mostrar-se mais forte em laços sentimentais do que um casamento combinado. São conhecidos alguns casos de homens que nutriam fortes sentimentos pelas suas concubinas: Filóneos e a sua concubina escrava (Antipho 1.14-20), Euctémon e Alce (Is. 6.17-26), Olimpiodoro e a sua concubina liberta ([D.] 48.53-56), Estéfano e Neera (e.g. [D.] 59.37-39), Frínion e Neera ([D.] 59.33-34), Timanóridas e Êucrates e Neera ([D.] 59.29-32), entre outros casos.

Em Atenas, as concubinas eram em geral bem aceites e o concubinato era reconhecido como uma forma de união estável. Embora a monogamia fosse a regra em Atenas, um cidadão podia ter uma ou mais concubinas, ou mesmo heteras, a par da sua esposa legítima. Tinha de ter, no entanto, recursos financeiros suficientes para

${ }^{13}$ Kapparis (1999: 10). 
manter uma residência separada para elas (e.g. Is. 6.21), pois não era tolerado levá-las e mantê-las na casa onde residia a sua esposa legítima e as outras mulheres da família (e.g. And. 1.124-125, 4.14-15; [D.] 59.22).

Nem sempre o conhecimento desta realidade era pacífico. Por vezes, o fato de um homem ter uma concubina para além da sua esposa legítima não devia ser motivo de grande alegria para a família desta última (e.g. Is. 6.21).

A designação inicial para a mulher que exercia a profissão de prostituta era a porne (prostituta) ou mesmo a pornidion (jovem prostituta). No entanto, bem cedo se recorreu à forma metafórica e eufemística hetaira para designar a cortesã como "uma companheira de afetos" e também "uma companheira para o divertimento". A palavra hetaira designava etimologicamente uma companheira ou amiga, embora cedo passasse a identificar uma cortesã ou hetera. De fato, hetera era aquela que acompanhava e fazia companhia aos homens, bebendo e comendo com eles (cf. [D.] 59.24).

A hetaira não era identificada como uma simples prostituta, mas como uma mulher de amores livres. Tinha uma vida muito mais independente do que a da esposa legítima e podia ser objeto de prestígio.

Torna-se importante referir que no vocabulário grego existiam duas formas para designar a simples prostituta e a cortesã: porne e hetaira, respetivamente. Parece pois que as duas designaçóes teoricamente náo tinham a mesma abrangência. A hetera mantinha um certo distanciamento da porne por manter relaçóes 
mais elitistas e ter uma postura mais fina do que esta. A hetaira correspondia normalmente a uma prostituta de um nível social elevado.

Uma mesma mulher pode ser descrita por um orador como porne, e como hetaira por outro orador, ou até mesmo noutro passo do mesmo discurso. É o caso de Sinope que é referida por Apolodoro ([D.] 59.116) como hetaira, e por Demóstenes (D. 22.56) como porne.

Um outro exemplo é o de Neera que era uma cortesã da classe alta, e por isso de gostos caros, sustentada por homens conhecidos e ricos. Estava habituada a viver em ambientes luxuosos e a usufruir de presentes, viagens, festas, afetos e atençóes dos seus amantes abastados. Nunca foi uma prostituta comum que tivesse tido necessidade de trabalhar num bordel para sobreviver (e.g. [D.] 59.29-32). Apolodoro sabe tudo isso, mas para atingir a sua imagem e conseguir os seus intentos diante do júri apresenta-a como uma mulher que mantinha um envolvimento sexual diário com clientes, como se tratasse de uma prostituta comum. ${ }^{14}$

A porne era a prostituta comum, escrava ou livre, que se estabelecia num bordel, onde recebia habitualmente diversas visitas masculinas, a troco de honorários modestos. Em Atenas, as pornai eram numerosas no bairro do Ceramico e no Pireu.

A prostituição feminina era legal e era tratada como uma profissão, embora tivesse má reputação. Existiam

${ }^{14}$ Cf. Kapparis (1999: 229, 408-409). 
muitas outras ocupaçóes tidas como inconvenientes quando associadas a mulheres de níveis sociais elevados (cf. D. 57.45). Náo era ilegal para mulheres cidadãs serem cortesãs, mas era provavelmente raro. As mulheres que eram de nascimento livre poderiam alcançar um preço superior, porque os homens apreciavam mais ter relaçóes sexuais com mulheres livres do que com escravas ou libertas. Poucas foram as filhas de cidadãos que se tornaram heteras. Isso acontecia devido à pobreza ou quando, após a morte do marido, se encontravam na miséria.

Havia essencialmente duas categorias de prostitutas. Havia aquelas mais comuns que se estabeleciam em bordéis e que eram acessíveis a qualquer homem, e praticavam preços baixos. Outras, de nível superior, praticavam um tipo de vida mais luxuoso e dispendioso, associado a uma clientela mais elitista e influente.

Kapparis considera ainda a existência de duas variantes dentro da primeira categoria de prostitutas: aquelas que se estabeleciam num bordel, e aquelas outras que exerciam a prostituição frequentando as ruas. ${ }^{15}$ Nesta última variante, elas estavam entregues a si próprias; na anterior havia habitualmente um supervisor que controlava a atividade aí exercida (e.g. Is. 6.19; Din. 1.23; Aeschin. 1.74).

A hetaira era uma mulher que se envolvia emocionalmente com homens ricos, agradáveis e influentes, com quem mantinha relaçóes amorosas mais

${ }^{15}$ Kapparis (1999: 312-313). 
longas e estáveis do que a porne ([D.] 59.29-35). Como forma de cativar uma clientela mais seletiva e elitista, a hetaira desenvolvia uma personalidade mais atraente e erudita, tendo havido muitas heteras que se notabilizaram pela sua beleza, luxo, graciosidade e cultura. Ler, escrever e alguma educação constituíam ferramentas úteis e fundamentais para o sucesso do seu negócio. Dessa educação podia fazer parte o desenvolvimento do seu humor, da sua habilidade para manter uma conversa e ainda qualidades artísticas tão necessárias num ambiente urbano, como a música e a dança.

Dispomos de pouca informação sobre a forma como as heteras se maquilhavam, se vestiam, se apresentavam e se comportavam em público, de maneira a se distinguirem das mulheres honestas de família. No texto que se tornou famoso pelo tema da prostituição, [D.] 59, precisamente o discurso Contra Neera, nada é referido sobre a indumentária fina, extravagante e transparente, a profusão de bijutarias, a maquilhagem ou os adornos do cabelo deste tipo de mulher (cf. e.g. Ar. Ec. 929, 1072, Lys. 42-48, 150; X. Oec. 10.2, 7). Parecia implícito, assim como hoje acontece, que a extravagância e a bizarrice eram as grandes aliadas das heteras para que as suas pessoas e, em particular, a sua beleza e saúde fossem realçadas. Nesta profissão tornavam-se necessários todos os tipos de artifícios para parecer bem, a fim de que o sucesso de uma hetera ficasse garantido e qualquer defeito físico fosse disfarçado.

A vida das heteras caracterizava-se de igual modo por se ausentarem com facilidade de casa e por 
se mostrarem e passearem com à vontade pela rua, ao contrário do que acontecia habitualmente com a mulher de família. Esta caraterizava-se pelo recolhimento e ainda por uma certa pudicícia e vergonha ao contactar com o exterior (e.g. Lys. 3.6; D. 21.79, [D.] 47.60).

As heteras participavam nos banquetes, symposia, fazendo companhia aos homens, e nessas ocasióes a música, a dança e o vinho eram os principais ingredientes (e.g. Is. 3.14; [D.] 59.24-25, 28). Alguns homens sob a influência do vinho poderiam lutar por uma cortesã (Lys. 3.43; D. 54.14). Muitos testemunhos iconográficos mostram cenas de banquete, de conversa amorosa e momentos de sedução em que estas mulheres aparecem ao lado dos homens, quer vestidas, quer desnudas (e.g. Ar. Ra. 513-516).

Os homens passaram a procurar a companhia das cortesãs não só com a intenção de terem um encontro físico, mas como um complemento necessário à sua vida no domínio erótico e emocional, como forma de preencher lacunas que a esposa legítima habitualmente não preenchia.

Nem sempre as heteras recebiam dos seus amantes ricos pagamento direto pela prestação dos afetos amorosos. Essa contribuição monetária era habitualmente substituída por presentes generosos ou auxílios financeiros nas despesas domésticas (e.g. [D.] 59.21, 29, 36, 42, 49). Ou então, para além do pagamento habitual, o amante podia ainda gastar dinheiro em joias e adornos, roupas, criadas (e.g. [D.] 59.46), banquetes (e.g. Ar. V. 1219; [D.] 59.24, 
48), e outras despesas para viagens, conforto e bemestar (e.g. [D.] 48.55, [D.] 59.21, 22, 108). Também podia acontecer que uma família inteira dependesse do trabalho como prostituta do seu principal membro feminino, como é, por exemplo, o caso de Neera ([D.] 59.39 e 42).

Como regra geral, a manutenção de uma cortesã associada a uma clientela de nível social elevado era uma dura tarefa de engenharia financeira, pois, devido aos seus hábitos excessivos e extravagantes, os gastos multiplicavam-se, podendo mesmo conduzir à ruína um homem prudente (e.g. Isoc. 8.103, 15.288; Aeschin. 1.132-137; [D.] 59.36, 39, 42).

Manter uma vida com uma hetaira significava para o homem um quotidiano repleto de disputas, de serenatas, de festanças e de constantes folias (cf. Is. 3.13). Quanto à transaçáo comercial que esta atividade aliava à sua existência, podia acontecer que uma hetera fosse alugada pelo seu amante ou amantes. Tal fato revela que este tipo de aluguer era uma prática frequente e reconhecida por lei, como mostra o discurso de Apolodoro, [D.] 59.26.

As escravas que eram cortesấs tinham um preço elevado em relação aos escravos que praticavam outro tipo de atividade. O preço médio de cada escrava cortesã rondava as vinte e as trinta minas de prata. Esta informação está presente em diversas fontes (e.g. Isoc. 15.288). Neera foi vendida a Timanóridas e a Êucrates por trinta minas, um preço alto para a média que era praticada ([D.] 59.29). Desta forma, a cortesã 
tornava-se propriedade do seu amante, mas algumas vezes ele podia permitir-lhe que ela passasse a usufruir uma vida menos subjugada ou adquirisse mesmo a sua liberdade, como são os casos referidos nos discursos contra Olimpiodoro e contra Neera, [D.] 48.53, 55 e [D.] 59.29-30, respetivamente.

É bem conhecido o caso de Nicareta ([D.] 59.1819) que comprou sete jovens escravas, entre as quais se contava Neera, para lhes ensinar a arte da sedução. Nicareta tratava-as por filhas com a intenção de obter o maior lucro possível das suas pupilas. Assim, fazendo-as passar por livres, podia cobrar honorários mais elevados àqueles que com elas mantinham intimidade. Deduzse, portanto, que o estatuto de cidadania e de liberdade fazia aumentar o valor e o prestígio da hetera.

A maior parte das jovens heteras iniciava a sua atividade profissional sob a orientação de uma mulher experiente e prática na arte da sedução, ou em muitos casos sob a direção da própria mãe, que na sua juventude havia exercido a mesma profissão. A jovem hetera era preparada, com tempo, para a futura profissão, aprendendo a cultivar a sua beleza e a arte de agradar, através da dança, canto e música. Esta mulher experiente que iniciava a jovem hetera guiava-a também na escolha de um amante sério e rico, que proporcionasse abundância e luxo. Ora, na presente situação, Nicareta toma o papel de protetora e guia de jovens que, sob a sua alçada, se hão de tornar heteras de profissão. 


\section{Histórias da Vida Privada}

Num discurso de índole judicial os acontecimentos e as pessoas envolvidas não são referidas ao acaso. A conjugaçáo de todos estes elementos tem o objetivo de atacar, demarcar, averiguar e baralhar os fatos jogados e o júri que os há de julgar. Se há dados que são duvidosos, e por vezes difíceis de provar, outros há que são verdadeiros. Avaliando os dados que este discurso oferece, parece ser claro que o seu principal objetivo é o de denegrir uma mulher da vida: Neera. Porém, para Carey, que tem outra interpretação, o principal objectivo é atingir Estéfano. ${ }^{16}$ Pode, no entanto, haver razões para discordar, em parte, desta visão de Carey. Embora Apolodoro diga abertamente, por diversas vezes ([D.] 59. 1, 16, 41-43, 49-61, 64-70, 72-84), que o seu interesse pessoal visa, em primeiro lugar, atingir e acusar Estéfano, é a Neera que o orador dedica um elevado espaço discursivo fazendo um relato pormenorizado da vida desta mulher, e da sua filha, antes e depois de conhecer Estéfano ([D.] 59.18-84). É evidente que Apolodoro se serve de Neera para denegrir o cidadão Estéfano. Contudo, nessa tentativa, a figura de Estéfano sai diluída ao passo que a de Neera sobressai, ficando a sensação de que é Neera a principal visada da acusação. O que Estéfano fazia antes de conhecer Neera é pouco relevante e, aliás, não é mencionado; a sua vida passa a ter especial interesse no momento em que se cruza com a de Neera. Náo se compreenderia a diferença entre o espaço discursivo dedicado a Estéfano e o dedicado a ${ }^{16}$ Carey (1992: 5). 
Neera se, de fato, a intenção fosse exclusivamente a de denegrir Estéfano.

Existem neste discurso três grupos de personagens. O primeiro é constituído pelos acusados: Neera, Estéfano e Fano. Neera é mulher de Estéfano. Fano é filha apenas de Neera. O segundo grupo comporta os oradores e o acusador do presente processo: Teomnesto e Apolodoro. Teomnesto era simultaneamente cunhado e genro de Apolodoro; conduz o discurso apenas no seu início. No terceiro grupo temos as vítimas dos acusados: Frastor, Epéneto e Teógenes, que são cidadãos.

$\mathrm{O}$ que é une estes três grupos de carateres? $\mathrm{O}$ fio da acusação: vingança. Estéfano tinha imputado a Apolodoro uma ação ilegal por este tentar transferir os fundos do theoricon para fins militares ([D.] 59.4-6). Mais tarde ainda acusa-o de assassínio de uma mulher ([D.] 59.9-10). Apolodoro e o cunhado retaliaram e atingiram Estéfano através de uma denúncia contra a sua mulher. $\mathrm{O}$ discurso é longo e cheio de vivacidade. A oratória e as leis estão nele intimamente unidas.

Neera é acusada de ter desposado um cidadáo ateniense, o que a sua condição de estrangeira a impossibilitava de fazer. Por detrás desta acusação direta, indubitavelmente verdadeira, há vingança pessoal e inimizade contra Estéfano levadas a cabo pelos dois oradores do discurso. Ao tentarem fulminar e desmantelar a vida atribulada de Neera, eles fá-la-ão acompanhar constantemente do intrépido Estéfano. Este é por eles representado como um pretenso legalista, cuja vida privada denunciava a encarnação da ilegalidade. 
Protagonista ou vítima da sua condição de vida fácil, Neera irá rechear e complementar os passos ousados de Estéfano no seu percurso de cidadão ateniense. E para uma trajetória tão completa de má conduta nada melhor do que um ser feminino para lhe consagrar um maior risco público.

Este discurso contém elementos discursivos de teor convencional, como o exórdio, a narrativa, as provas e o epílogo. No exórdio são dadas as motivaçóes do processo judicial. A narrativa apresenta as histórias da vida de Neera e da sua filha Fano. Nas provas são apresentados os elementos que ajudam a estimular a hostilidade para com a acusada, através da confirmação e da refutação dos argumentos. $\mathrm{O}$ epílogo insiste nos motivos da ação e, sobretudo, na ofensa religiosa.

A primeira motivação deste discurso é de ordem familiar. Vítima de grandes injustiças por parte de Estéfano, a família de Teomnesto e Apolodoro procura vingar-se através deste processo judicial. Os males causados por Estéfano a Teomnesto, a Apolodoro, à sua irmã e à sua esposa foram tâo grandes que quase conseguiram para estes o exílio e a atimia. Foi pois o bem-estar social e económico de toda uma família que foi posto em perigo. É na parte inicial do discurso que é possível obter informação sobre o primeiro orador, Teomnesto, e sobre os laços que o ligam a Apolodoro. Os acusadores de agora (Teomnesto e Apolodoro) foram outrora vítimas do atual acusado (Estéfano).

Um decreto ateniense tinha conferido a Pásion o direito de cidadania, assim como aos seus descendentes. 
Deste modo, o pai de Teomnesto deu a sua filha em matrimónio a Apolodoro, filho de Pásion. São dela os filhos de Apolodoro. Tudo corria pelo melhor e Apolodoro demonstrava respeito pela esposa ([D.] 59.2). Convém referir que estes pormenores, embora enunciados por Teomnesto, haviam sido redigidos por Apolodoro, ou seja, ele próprio se caracteriza. Teomnesto decidiu então casar com uma filha do casal, que era também sua sobrinha. Assim sendo, Apolodoro torna-se ao mesmo tempo seu cunhado e seu sogro ([D.] 59.2). Este tipo de casamento entre membros de uma família era comum na tradiçáo ateniense.

Entretanto, Apolodoro passa a fazer parte do Conselho, períododuranteoqual acidadeviviamomentos de guerra. Atenas poderia ser vitoriosa mantendo todo o seu poderio, vencendo Filipe da Macedónia ou, pelo contrário, poderia ver-se abandonada pelos seus aliados, sem a confiança dos outros Gregos e com os seus últimos domínios comprometidos. É interessante notar como até num discurso privado o estigma de Filipe marcava o horizonte da população civil. O impacto da figura macedónia sobre a população ateniense arrebatava-lhe a tranquilidade, levando-a à obsessão da sua omnipresença. Estas eram as circunstâncias da vida pública contemporânea de Apolodoro que antecederam uma proposta sua ao Conselho e posteriormente à Assembleia, aquando de uma expedição a Eubeia e Olinto. A proposta, cuja votação seria feita de mãos levantadas, pretendia decidir da aplicação do saldo da administração às despesas militares ou às do theoricon 
([D. ] 59.3-4). As leis ordenavam que em tempo de guerra o saldo da administração fosse afeto às necessidades militares. Porém, Apolodoro considerava que o povo devia decidir do que era seu como lhe aprouvesse.

Feita a votação, ninguém se opôs a que o saldo se destinasse a fins militares. Mas Estéfano atacou o decreto por ilegalidade, apresentando em tribunal falsos testemunhos de que Apolodoro seria devedor do erário público desde há vinte cinco anos e, recorrendo a acusaçóes exteriores ao processo, conseguiu levar o decreto à condenação ([D.] 59.5). Até aí não havia nada a dizer, se fora esse o resultado pretendido, mas quando chegou o momento da aplicação da pena Estéfano não cedeu a qualquer tipo de concessáo. Ele propôs uma multa excessiva de quinze talentos. Este fato conduzia Apolodoro e os seus descendentes à perda dos direitos cívicos e a esposa e os restantes familiares à miséria ([D.] 59.6). Se a multa náo fosse saldada até à nona pritania, duplicaria, e Apolodoro seria inscrito como devedor de trinta minas para com o erário. Toda a sua fortuna seria confiscada em proveito do Estado, o que traria a ruína aos seus filhos, à sua esposa e a todos os restantes familiares ([D.] 59.7). Além disso, como realça o orador, tal fato traria a impossibilidade de casar a segunda filha do casal. Esta filha perderia a possibilidade de constituir uma família legítima porque passaria a ser relacionada com um devedor público e com um homem arruinado que não lhe poderia oferecer um dote. $\mathrm{O}$ dote de uma rapariga constituía o seu passaporte legítimo para fundar uma família de cidadãos. O dote era um seguro que 
acompanhava uma jovem rapariga quando era chegado o momento de abandonar a casa paterna e ser entregue ao marido, no momento do contrato estabelecido entre o sogro e o genro. Algumas vezes o Estado ateniense podia conceder ajuda no dote a jovens filhas de homens que o tinham servido, mas que náo possuíam haveres próprios para as dotar. $\mathrm{O}$ problema para esta filha de Apolodoro era o de que náo podia contar com este auxílio se o seu pai caísse em desgraça.

$\mathrm{O}$ insucesso financeiro de um pai e a sua posterior limitação económica podia comprometer o futuro da filha ao privá-la do dote que em princípio a acompanhava num novo oikos, o do seu marido. Esta é uma ilustração típica dos laços familiares atenienses. Através do casamento a mulher cumpria a sua função de maternidade e, assim, não só satisfazia a sua realização pessoal como também um dever cívico. Este aspeto da vida feminina era comparável aos deveres e serviços públicos exercidos pelo lado masculino em relaçáo ao Estado. As obrigaçóes de família complementavam as obrigaçóes sociais para com a comunidade. Portanto, ao assegurar o bem-estar feminino, preservava-se também o sistema social em que assentava a polis ateniense, unidade fechada com regras próprias.

Os juízes apiedaram-se, no entanto, de Apolodoro e fixaram a multa num talento, de forma a que ela pudesse ser saldada. Contudo, esta não foi a única tentativa de Estéfano para afastar Apolodoro da cidade; imputou-lhe também uma falsa acusação de assassínio, através do suborno de alguns escravos, e acusou-o de 
matar à pancada uma mulher, depois de se ter deslocado a Afidna, para procurar um escravo fugitivo ([D.] 59.9). O perjúrio e a calúnia desta acusação foram reconhecidos ([D.] 59.10).

Em resposta a estas tentativas de destruição de uma família, a palavra de ordem era o castigo e a vingança contra Estéfano pelo mal exercido (cf. [D.] 59.11-12). Se ele havia mostrado desprezar as leis orgânicas do Estado assim como os decretos vigentes, tinha certamente olvidado a verdadeira ilegalidade que cometera ao tornar-se marido de uma estrangeira (cf. [D.] 59.12-13).

Estéfano tinha ultrapassado tudo e todos ao introduzir os filhos de Neera na sua fratria e no seu demo e ao dar em casamento, como sua filha legítima, a filha de uma hetera, despojando o povo do seu direito soberano de fazer cidadáo quem bem entendesse.

Esta é a primeira e principal acusação do discurso: Neera era uma hetera, mas passava por ser mulher do cidadão ateniense Estéfano (cf. [D.] 59.13).

Estéfano usara dos seus direitos de cidadão para imputar a Apolodoro uma acusação mas esquecera-se de utilizar para si as mesmas leis do Estado. $\mathrm{O}$ orador encarece os valores da estrutura familiar ateniense por contraponto à vida desregrada e livre de respeitos humanos de Estéfano e de Neera.

A estrangeira Neera é, pois, a primeira visada da acusação devido ao fato de ser esposa de Estéfano, à margem das leis da cidade ([D.] 59.14). A partir deste ponto Teomnesto solicita a assistência de Apolodoro, 
orador mais versado em leis e interessado particular em todo este caso, como advogado de acusação ([D.] 59.15).

A presença de Neera no tribunal é diversas vezes enunciada através do pronome deíctico hautei ([D.] 59.16, 19, 20, 24, 43, 44, 47, 55, 56, 62, 63 bis, 64 bis, $65,72,83,115,117,118,119)$. A repetição desta referência é uma estratégia de Apolodoro para chamar a atenção dos jurados sobre aquela presença feminina que é motivo de condenaçáo. Neera encontra-se ali no tribunal, fisicamente, próxima de todos. A presença de uma mulher num ambiente público como o de um tribunal parece ser por si mesma delituosa ou símbolo de outros delitos. As mulheres legítimas de Atenas tinham vidas recatadas. Neera, ao mostrar ostensivamente a sua presença, parece denunciar a ilegalidade da sua condiçáo privada. Aquela que é alvo da acusação por ter usufruído indevidamente de direitos sociais que não lhe estavam destinados revela, pela sua presença no tribunal, uma grande probabilidade de ser culpada. Esta constante e exaustiva repetiçáo e lembrança da presença de Neera ao longo do discurso culmina num pedido direto de Apolodoro aos membros do júri para que julguem Neera tendo em conta as leis que foram violadas e as provas apresentadas dos atos por ela perpetrados ([D.] 59.115. O fato de observar a própria arguida parecia ajudar a tomar a melhor decisão sobre o seu futuro. A presença de Neera em tribunal e, em particular, na audiência parece ajudar a versão dos acontecimentos apresentada por Apolodoro ao criar ansiedade em redor da sua pessoa. 
Não se conhece da parte de Neera qualquer reação, embora ela estivesse fisicamente presente no tribunal. Este fato não surpreende porque o discurso que representa a sua pessoa é enviesado por um interesse supremo: vencer uma causa em tribunal. O silêncio que envolve a sua figura é, contudo, revelador da densidade dramática que a resolução do seu caso transporta. A presença de Neera no tribunal parece ser gritante para Apolodoro; o fato de ser uma presença silenciosa parece ser gritante como símbolo das mulheres da Grécia antiga. Independentemente da sua condenação, o percurso de vida de Neera era uma ofensa para qualquer mulher cidadá. $\mathrm{O}$ silêncio de Neera, para além de ser uma atitude obrigatória, pode, pois, ser considerado um elemento portador de significado.

Mesmo que uma mulher fosse parte de um processo judicial, ela era habitualmente representada em tribunal pelo seu kyrios ou por qualquer outra pessoa, do sexo masculino, interessada no caso. Neera é defendida por Estéfano que era seu amante e protetor. Mas, por exemplo, num discurso de Antifonte (Antipho 1), a madrasta acusada de ter morto o marido é defendida pelo seu filho. No presente discurso Neera não possuía o estatuto de cidadá. A madrasta representada por Antifonte é uma cidadã que faria tudo para evitar o olhar acutilante e recriminatório do público espetador, sobretudo quando está sob a acusação de homicídio. Não há qualquer referência legal que inibisse ou exigisse a presença ou a ausência de qualquer uma destas mulheres em tribunal. Porém, era hábito as cidadãs não 
participarem em julgamentos, nem como litigantes, nem como testemunhas, nem mesmo como apoiantes dos maridos.

No entanto, parece evidente que as mulheres que não possuíssem o estatuto de cidadania náo sofriam de pudor por se apresentarem e mostrarem em público, ao contrário daquelas que o possuíam e cuja invisibilidade era sinal de reserva, própria do seu estatuto social e, sobretudo, de boa conduta. Do ponto de vista social, a própria cidadania parecia transmitir às mulheres que a possuíam um caráter inibidor e moralizador, ao mesmo tempo que garantia uma capa de respeitabilidade.

$\mathrm{O}$ fator da idade também possibilitava uma maior mobilidade e liberdade à mulher. Uma mulher de idade mais avançada sentia-se menos coagida e limitada pelos hábitos sociais, pois a sua idade transportava o peso do respeito inquestionável devido aos mais velhos.

Assim, e por regra, a mulher estava ausente fisicamente do espaço público do tribunal, o que the permitia preservar a sua imagem social. Porém, a presença feminina podia fazer-se sentir no espaço forense através do discurso público dos litigantes, tal como acontece, aliás, na oração de Apolodoro.

Apolodoro inicia, então, o seu discurso através de uma breve introdução que valoriza a base legal da acusação. Neera é acusada de forma direta por ser estrangeira e esposa de Estéfano, contrariamente ao que as leis lhe permitiam. O texto legal é citado para dar força persuasiva ao seu argumento. A leitura de documentos, tais como leis e decretos, era habitual 
nos discursos na Assembleia e nos tribunais, como elemento embelezador do argumento retórico. Não é de afastar, porém, uma interpretação que veja neste aspeto uma estratégia de fundamentação do que é afirmado pelo orador em questão. Se um estrangeiro se torna marido de uma ateniense, poderá ser-lhe imputada uma acusação, por qualquer motivo, diante dos tesmótetas por qualquer ateniense na posse dos seus direitos. O condenado será vendido, assim como os seus bens, e um terço da venda do produto reverte a favor do acusador. E o mesmo acontece se uma estrangeira é esposa de um ateniense. $\mathrm{O}$ marido da estrangeira condenada ficará sujeito a uma multa de mil dracmas ([D.] 59.16).

Apolodoro explicita que, para além da impossibilidade de casamento, são ainda ilegítimos os filhos de tais unióes ([D.] 59.17). Para fortalecer o seu argumento, o orador avança para uma narrativa minuciosa.

A narrativa ([D.] 59.18-84) comporta o relato da carreira de Neera e mais tarde o da filha Fano, com a inclusão de episódios ilustrativos próprios das andanças mundanas destas duas mulheres da vida (cf. Is. 3.13-14).

A carreira de Neera ([D.] 59.18-48) é descrita com episódios biográficos de destemido companheirismo, festas e banquetes, libertinagem, má conduta e utilização profissional do corpo. A caracterização de Apolodoro começa com o comportamento de Neera desde a sua juventude e continua progressiva e cronologicamente através da sua carreira. 
Os antecedentes de Neera recuam a Nicareta, uma liberta que era mulher do cozinheiro Hípias. Esta Nicareta adquiria jovens raparigas a quem reconhecia beleza, para as criar e educar. Chamava-lhes filhas, de modo a obter lucro pecuniário daqueles que as pretendiam por as julgarem livres ([D.] 59.18-19, 118). No entanto, fica claro no texto que Neera, assim como outras seis jovens, fora comprada, ainda muito jovem, por Nicareta ([D.] 59.18). Quer isto dizer, sem qualquer dúvida, que ela era escrava anteriormente.

Da vida de Neera nesses tempos são narrados dois episódios que demonstram que a prostituiçáo era o seu modo de vida. Num dos episódios Neera é vista ([D.] 59.21-23) juntamente com Nicareta e uma das suas jovens, Metanira, disposta a alojar-se em casa de Lísias, um amante desta última. Num interessante detalhe psicológico, este amante recusa alojá-las na sua própria casa ao lado da sua esposa legítima e da sua idosa máe. Dir-se-ia que esta situação despertou neste amante um pudor doméstico em aproximar dois tipos de mulheres: as da vida legítima (a sua esposa e a sua mãe) com as que vendem o prazer do corpo (Nicareta, Metanira e Neera).

Noutra ocasião, Neera é descrita a acompanhar Simo, o Tessálio, assim como Nicareta, às Grandes Panateneias, e a festejar em casa de Ctesipo, filho de Glauconides, em numerosa companhia, como se fosse uma hetera. O comportamento de Neera era licencioso e próprio de uma mulher que praticava a prostituição (cf. [D.] 59.24). Todos estes fatos foram sempre 
confirmados através da presença de testemunhos ([D.] 59.23 e 25$)$.

Continuando a percorrer a vida de Neera, Apolodoro mostra-a em Corinto a exercer em pleno a sua profissão de prostituta. Aqui é vista ladeada de amantes, entre os quais Xenoclides, o poeta, e Hiparco, o ator ([D.] 59.26), como se os atributos profissionais destas duas personagens ajudassem a caracterizar o aspeto teatral da conduta da companheira de ambos. Apenas Hiparco pôde testemunhar. Xenoclides estava sujeito a atimia e, como tal, o direito à palavra era-lhe vedado. Tal fato tinha sido consequência duma querela prévia com Estéfano ([D.] 59.27-28).

Posteriormente, outros dois amantes aparecem no seu horizonte: Timanóridas, o Coríntio, e Êucrates, o Leucádio ([D.] 59.29-30), que a compram como escrava a Nicareta por trinta minas para poderem usufruir dela sem restriçóes. Depois, como tivessem decidido casar-se os dois, comunicaram a Neera que não a queriam ver a trabalhar em Corinto, nem sujeita a um pornoboskos. Desejavam também, no entanto, que a sua antiga hetera ficasse numa boa situação. Como tal, decidiram contribuir com mil dracmas para a sua liberdade. Para perfazer o montante em falta, por eles pago na ocasião da sua aquisição (isto é, vinte minas), eles convidaram-na a arranjá-lo e a remeterlho quando os tivesse. E assim aconteceu. Através de uma colecta junto dos seus antigos amantes, entre os quais se contava Frínion, filho de Démon e irmão de Demócares, e acrescentando ela própria o resto, Neera consegue comprar a sua liberdade ([D.] 59.30-32). 
Já com um novo estatuto, o percurso de vida libertina de Neera prossegue ao lado de Frínion. Ela acompanhava-o a banquetes e a qualquer parte onde se bebesse, assim como participava em cortejos com ele. Quanto a ele, estava com ela publicamente em todo lado, sempre que o desejava. Neera levava uma vida de pândega e libertinagem, mas condimentada com abuso e devassidão ([D.] 59.33-34). Porém, depois de começar a sofrer ultrajes seus, resolve abandoná-lo, fugindo para Mégara com os objetos da casa dele e com as roupas, joias e duas servas que do mesmo recebera ([D.] 59.35). Contudo, os tempos megarenses foram difíceis devido à guerra dessa época, pela tendência do Megarense para a avareza, por não poder regressar a Corinto e, sobretudo, pelo fato de Neera ser bastante gastadora ([D.] 59.36). Por ocasião da batalha de Leuctros, decorrida em 371 a. C. entre Tebanos e Lacedemónios, Estéfano estabelece-se em Mégara e aí trava conhecimento com Neera. Aloja-se em sua casa, pois ela era hetera, e com ela mantém relaçôes íntimas. Neera aproveita então para o tornar seu protetor, temendo a reação e a violência de Frínion ([D.] 59.37).

Estéfano decide então protegê-la, garantindolhe que a faria sua mulher e que os filhos que ela tinha os apresentaria aos membros da fratria e os tornaria cidadãos. De Mégara decidem partir para Atenas. Estéfano, Neera e os três filhos dela, que davam pelo nome de Próxeno, Aríston e Fano ([D.] 59.38, cf. [D.] 59.121), instalam-se na pequena casa de Estéfano, que 
era tudo o que possuía. ${ }^{17}$ Com esta companhia feminina, ele encontrara uma hetera formosa gratuitamente e com o seu ofício arranjaria o suficiente para manter a casa, pois a subsistência de Estéfano apenas rondava os lucros da chantagem que ele costumava exercer ([D.] 59.39). É então que Frínion aparece a reivindicar o regresso de Neera. Estéfano defende a sua liberdade, mediante o pagamento de uma fiança junto do polemarco ([D.] 59.40, cf. [D.] 59.45).

Mesmo depois de ter sido libertada pela fiança paga por Estéfano, Neera continuou a exercer a sua profissão anterior. No entanto, passou a cobrar honorários mais elevados a quem queria ter relaçôes íntimas com ela, sob o pretexto de que já possuía uma situação familiar aparente e vivia com um marido. Deste modo, inicia-se um percurso cheio de feitos e façanhas coloridas ao lado de Estéfano, agora que existia uma fachada de marido e mulher. De conivência com Neera, Estéfano sobrevivia à custa de chantagem, atuando como um sicofanta ([D.] 59.41, cf. [D.] 59.43). Sempre que podia aproveitava-se de um estrangeiro rico e ignorante dos fatos, sequestrava-o em sua casa como adúltero e cobrava-lhe muito dinheiro em troca da sua libertação ([D.] 59.41). Um estratagema similar de chantagem será utilizado pelos dois a respeito de Fano, filha de Neera, contra Epéneto de Andros (cf. [D.] 59.64-71).

Esta foi a forma que os dois encontraram para fazer face aos gastos diários e à administração doméstica, que

${ }^{17}$ Porém, numa outra parte do discurso é afirmado que havia mais um filho de nome Antidorides, que, neste momento do discurso, não consta da referência de Apolodoro ([D.] 59.121). 
eram elevados. Pois havia que sustentar a família que era constituída pelos três filhos dela, por duas escravas e por um criado. Além disso, Neera aprendera a não poupar nas comodidades ([D.] 59.42). Quanto a Estéfano, praticava a sicofantia sem qualquer pudor, desprezando as leis, os seus concidadãos e os deuses ([D.] 59.43-44). Tais práticas faziam com que Apolodoro o considerasse merecedor de um castigo não inferior ao de Neera ([D.] 59.44). Estes aspetos do quotidiano de Estéfano pretendem acentuar a personalidade oportunista que caraterizava o companheiro de Neera, fazendo com que este casal formasse uma união perfeita de vida licenciosa.

Frínion não ficara, contudo, satisfeito com o anteriormente acordado e retoma uma ação jurídica contra Estéfano, por este lhe ter tirado Neera e por ele ter aceite os objetos que ela trouxera consigo da sua casa ([D.] 59.45). O desfecho deste episódio assenta num mútuo acordo entre as três partes. Neera deveria restituir a Frínion aquilo que trouxera da casa de Frínion, à exceção dos vestidos, joias e escravas que tinham sido comprados para ela. Além disto, ela passaria a viver com cada um deles, de dois em dois dias ([D.] 59.46).

Durante quanto tempo durou este acordo não sabemos. Para caraterizar com mais força este episódio da vida de Neera, Apolodoro faz referência àqueles que confirmaram e assistiram à transação, e ao modo como Neera se comportava como uma verdadeira hetera quando tomava parte no banquete e quando bebia sempre que se encontrava com cada um dos seus companheiros ([D.] 59.47-48). 
Após este relato, o orador faz um corte entre estes acontecimentos e a narraçáo da vida de Fano, a filha de Neera. Este tipo de corte, assim como o recurso ao excesso de pormenores e testemunhos, revela um estilo oratório desajeitado, com pouca elegância e com falta de capacidade de selecionar os fatos mais relevantes da vida de Neera e da sua família direta. Estas caraterísticas colocam Apolodoro a grande distância do autor de um De Corona (D. 18). Antes de passar a outro aspeto sensível da acusação, a filha de Neera, o orador faz um ponto da situação, resumindo os aspetos fundamentais da vida de Neera até àquele momento do discurso.

O percurso biográfico de Fano ([D.] 59.50-84) está igualmente cheio de pormenores e historietas de costumes pouco ortodoxos. Era como se Apolodoro quisesse mostrar abertamente que de uma mãe como Neera só podia resultar uma filha que seguisse os passos da mãe (cf. [D.] 59.50). Apolodoro salienta as relaçôes que Fano manteve com Frastor, com Epéneto, com Teógenes e ainda as suas digressóes como basilinna. $\mathrm{O}$ discurso de Apolodoro é rico em pormenores biográficos de Fano. $\mathrm{O}$ tribunal fica a saber (cf. [D.] 59.38 e 50) que ela havia tido anteriormente o nome de Estribele. Não são reveladas as razóes por que Apolodoro salienta esta mudança. Parece evidente, no entanto, que o efeito pretendido é o de destacar a instabilidade da vida e do dia a dia desta família, instabilidade de tal forma grande que até os nomes próprios sofrem alteraçóes. Além disso, havia necessidade de ocultar traços do passado que pudessem comprometer o futuro promissor que se pretendia conquistar. 
A carreira desta jovem, sempre ladeada por Estéfano e Neera, não vai afastar-se muito da já percorrida por sua mãe. A sua história matrimonial começa com o casamento que Estéfano lhe arranja. Este dá-a, como se ela fosse sua filha, a um ateniense de nome Frastor de Egília, acompanhada por um dote de trinta minas.

Com a atribuição do dote, Estéfano pretendia envolver a uniáo matrimonial numa capa de legitimidade, de rigor e de boas intençóes para com o marido que arranjara para a sua enteada. Bem cedo, contudo, o casamento desmoronou-se. Frastor era um homem comedido e equilibrado, e que se habituara a poupar. Fano não sabia adaptar-se aos hábitos de Frastor ([D.] 59.50-51).

Quem estava habituada à licenciosidade cedo se cansa da vida simples da mulher casada. Frastor não lhe encontrava maneiras, nem doçura. Quando Frastor se apercebeu que tinha sido ultrajado e enganado pelas artimanhas de Estéfano, ao garantir-lhe que ela era sua filha legítima, que nascera de uma esposa ateniense antes de viver com Neera, ao fim de um ano de casamento, e estando ela grávida, despediu-a, sem devolver o dote ([D.] 59.51, 63).

Estéfano intenta uma ação contra Frastor, uma dike sitou, diante do Odéon, com vista a assegurar à mulher tutorada recursos alimentares, pois a lei obrigava o marido, em caso de repúdio, a restituir o dote ou, na sua falta, os juros à taxa de nove óbolos ([D.] 59.52).

Por seu turno, Frastor intenta uma ação pública diante dos tesmótetas contra Estéfano por este lhe ter 
dado em casamento a filha de uma estrangeira, indo contra o que a lei estabelecia ([D.] 59.52, 62), para o que a pena podia ser a atimia ou a confiscação de bens. Receando tais resultados, Estéfano renuncia ao dote e retira a ação de dike sitou, assim como Frastor retirou a sua acusação ([D.] 59.53-54). Estéfano percebeu que náo devia assustar o marido de Fano com demasiadas exigências, nem suscitar muita atenção sobre a ilegitimidade da sua enteada, sobretudo num momento em que as relaçóes familiares estavam tão fragilizadas e Fano se tornara mãe de um filho de Frastor.

Entretanto, depois que Frastor repudiou a filha de Neera, ficou bastante doente ([D.] 59.55). Nessa altura, à força de cuidados, presença e dedicação de Neera e da sua filha alguma harmonia se conseguiu consertar. Frastor acabou por reconhecer a criança de Fano como seu filho. O fato de estar muito doente e com pouca esperança de vida, de não ter filhos, os cuidados que recebera daquelas mulheres, uma antiga inimizade que Frastor mantinha com os seus parentes e o desejo de não lhes deixar a sua herança forçaram-no a tomar a decisão de reconhecer o filho de Fano como seu ([D.] 59.55-58, 63).

Facilmente se percebe o caráter universal e a eficácia destes atos femininos, pois qualquer que seja a mulher, a sua natureza, ou o seu estatuto, a sua presença é sempre valiosa à cabeceira de um homem doente. A dedicação de Neera e de Fano na doença de Frastor teve como único objetivo persuadir Frastor a tomar de volta e a reconhecer o filho de Fano. Para Apolodoro, a iniciativa de reconhecimento desta criança não foi 
tomada de livre vontade, mas forçada pela situação de desamparo e fragilidade que a doença fizera nascer (cf. [D.] 59.59).

Mais tarde, após ter recuperado daquela enfermidade, Frastor volta a casar, desta vez com uma ateniense legítima, conforme a lei ([D.] 59.58, 63). Depois disto quis fazer admitir o filho que tinha tido da filha de Neera na fratria e no genos. Mas os seus membros, que reconheciam a sua primeira mulher como sendo filha de Neera, votaram contra a admissáo da criança e ela não pôde ser inscrita entre eles ([D.] 59.59, 63). Frastor ripostou a este fato com um processo. De nada lhe valeu, pois não quis prestar um falso juramento e declarar que o seu filho era nascido de uma ateniense ([D.] 59.60-61, 63). Eram três os requisitos inerentes à aceitação por uma fratria de um filho gnesios: convicção da paternidade pelo pai; a qualidade de aste na mãe; e a engyesis precedente ao matrimónio. Neste caso particular, o que parece faltar para tal aceitação é a qualidade de aste da mãe e, consequentemente, também a engyesis. Aliás, a engyesis só tinha validade jurídica quando ocorria entre um pai, com o estatuto de cidadáo, que dava uma filha legítima em casamento, e um marido também ele cidadáo. Fano, filha de Neera, nascida de um cidadáo e de uma xene, é portanto também uma xene e, por essa razão, xenos é o filho nascido de Fano e Frastor.

Esta situação constitui uma importante ajuda ao processo de Apolodoro porque é mais um elemento que confirma a ilegitimidade de cidadania de Neera e, 
consequentemente, do seu casamento com Estéfano (cf. [D.] 59.62).

Fazendo uso da sua avidez, vilania e maldade, Estéfano lança uma armadilha a Epéneto de Andros. Este era um antigo amante de Neera, que tinha gasto muito com ela e que se alojava em casa de Estéfano e Neera sempre que vinha a Atenas, por causa da amizade que mantinha por ela ([D.] 59.64). Sob o pretexto de oferecer um sacrifício, Estéfano convida-o para o campo e, fabricando um dolo, apanha-o em flagrante delito com a filha de Neera, prendendo-o por adúltero (cf. [D.] 59.65). Por esse fato, Estéfano infunde-lhe medo e cobralhe trinta minas. É interessante notar que essa quantia correspondia exatamente ao valor do dote do primeiro casamento de Fano com Frastor (cf. [D.] 59.50), e que o marido, quando se separou dela, não devolveu (cf. [D.] 59.63). O estratagema de Estéfano visava, com toda a certeza, aproveitar-se de um homem rico como Epéneto para fazer face ao investimento financeiro totalmente perdido no dote do casamento de Fano.

Só depois de ter recebido a garantia do seu pagamento, através de fiadores, é que Estéfano o solta ([D.] 59.65). Liberto desta situação, Epéneto responde com uma acusação pública contra Estéfano por sequestro, por ter sido vítima de uma maquinação contra o direito e por extorsão ([D.] 59.66). Ora Epéneto de Andros, que era íntimo daquela família, devia conhecer todos os pormenores a seu respeito e, por isso, se soubesse que Fano estava casada com Frastor, não se envolveria com ela, pois devia saber quais as consequências punitivas 
do seu ato. Assim, a noção de moicheia, quer dizer, adultério, aparece aplicada a uma relação sexual com uma mulher não casada. Contudo, também podia fazer parte do plano de Estéfano, quando acusou Epéneto de ser adúltero, convencê-lo, sub-reticiamente, de que Fano seria ainda uma mulher casada e, nessa situação, ele ao ser apanhado com ela em flagrante seria considerado um moichos, um adúltero. Se esta acusação conseguisse ser levada a cabo, Estéfano lograria obter dividendos. Talvez fosse essa a primeira intenção da armadilha lançada por Estéfano a Epéneto. Mas, de fato, Epéneto não podia ser acusado de adultério, pois Frastor já se tinha separado de Fano e até já tinha contraído um novo matrimónio com uma mulher cidadã (cf. [D.] 59.63).

Quanto à defesa de Epéneto nesta acusação, ela apoiava-se no seguinte argumento. Epéneto reconhecia em primeiro lugar que tinha mantido relaçóes com Fano, mas não aceitava que pudesse ser considerado um adúltero devido a isso, pois ela não era filha de Estéfano, mas sim de Neera. Em segundo lugar, Fano tinha-se unido a ele com o conhecimento da mãe. Finalmente, o argumento era acompanhado com a informação preciosa de que ele sempre despendera enormes somas com Neera e Fano quando se deslocava a sua casa em Atenas. $\mathrm{Na}$ verdade, a casa de Estéfano era uma casa especial: a prostituição era aí profissão.

Estéfano, talvez receando ser reconhecido como um comerciante de raparigas e um sicofanta, propóe um acordo com os fiadores e com Epéneto, de tal forma que Epéneto é convencido a retirar a acusação ([D.] 59.68- 
69). No momento da reunião conciliatória, Estéfano não tinha nenhuma reivindicação legal a fazer. Estéfano apenas solicitou a Epéneto que contribuísse para o dote da filha de Neera, mencionando a sua própria pobreza e a má sorte que Fano tivera anteriormente com Frastor. Acrescenta ainda que, como tinha perdido o dote de Fano, não poderia dá-la de novo em casamento ([D.] 59.69). E, para melhor persuadir Epéneto a fornecer uma contribuição, afirmou que, já que ele se tinha aproveitado dela, seria justo que ele fizesse algo por ela. Então os árbitros daquela contenda reconciliam os dois homens e persuadem Epéneto a contribuir com mil dracmas para o dote da filha de Neera. Em compensação, Estéfano colocava Fano à sua disposição sempre que ele se deslocasse a Atenas e quisesse estar com ela ([D.] 59.70-71).

É, pois, por ocasião da reconciliação entre Estéfano e Epéneto que Fano é reconhecida publicamente como estrangeira, como aliás confirma Apolodoro ([D.] 59.72).

A acusação de fraude e extorsão feita por Epéneto contra Neera e Estéfano é a repetição de uma outra acusação, referida no início do discurso ([D.] 59.41). A pretexto de viver maritalmente com Neera, Estéfano tinha por hábito sequestrar como adúltero algum estrangeiro rico em sua casa e, a esse propósito, cobrava-lhe muito dinheiro.

Não sendo ainda suficientes todas estas aventuras, Estéfano e Neera procuram mais um alvo. Esse outro alvo vai ser Teógenes de Corónides. Era um homem 
de nascimento nobre, mas pobre e sem experiência em assuntos públicos, que tinha sido designado arconte-rei. Aproveitando-se disso, Estéfano aproximou-se dele, ofereceu-lhe ajuda financeira e, através de subterfúgios, conseguiu tornar-se seu assessor. Dá-lhe em casamento a filha de Neera, como se fosse sua filha, desrespeitando as leis e os seus concidadãos ([D.] 59.72). A mulher do arconte-rei devia exercer algumas funções religiosas, como a de assistir aos sacrifícios secretos da cidade, direito que a lei interditava a uma estrangeira (cf. [D.] 59.75-76). Ela, porém, recebeu o juramento das sacerdotisas, foi dada em casamento a Dioniso e realizou em nome da cidade os ritos tradicionais em honra dos deuses, cerimónias essas que são numerosas, santas e secretas ([D.] 59.73).

A lei promulgada sobre a mulher do arconte-rei especificava que ela devia ser cidadã e que ele se casasse com uma mulher que náo tivesse conhecido nenhum outro homem, isto é, que fosse virgem ([D.] 59.75). Esta lei, gravada sobre uma estela de pedra, tinha-se mantido ao longo dos tempos. O povo cumpria-a em sinal de piedade e respeito ao seu deus Dioniso ([D.] 59.76)..$^{18}$

Estes fatos suscitam a revolta de Apolodoro e uma veemente chamada de atenção para o sacrilégio cometido. Este sentimento do orador culmina numa breve história acerca do aparecimento da magistratura do arconte-rei e da sua vitalidade no seio da sociedade, e ainda no inventário das qualidades que a mulher do arconte devia

${ }^{18}$ Cf. Kapparis (1999: 319-320, 324-331). 
possuir ([D.] 59.74-77). Esta referência cultural e religiosa pretende acentuar, por contraste, o caráter libertino, desrespeitoso e amoral do comportamento de Fano.

$\mathrm{O}$ orador documenta estas revelaçóes sobre o caráter augusto, santo e antigo destes ritos com o próprio juramento das mulheres veneráveis que assistem o deus junto do seu altar. Promete ele próprio revelar mais um testemunho para este caso. Trata-se do momento em que se celebraram estes sacrifícios e os nove arcontes subiram à colina de Ares ([D.] 59.78).

Depressa o Conselho do Areópago investigou quem era a mulher de Teógenes, e cedo chegou à verdade. Para evitar escândalo, o Conselho deliberou, "em segredo e com discrição" ([D.] 59.80), condenar Teógenes, que se justificou com o total desconhecimento de ter desposado e ter levado a tal cargo uma mulher como aquela, pois fora enganado por Estéfano que se aproveitara da sua própria inexperiência em assuntos públicos ([D.] 59.81-82).

Em consequência destes acontecimentos, Teógenes garantiu ao Conselho que iria despedir de sua casa a filha de Neera, com quem casara em total ignorância do seu verdadeiro historial de vida (cf. [D.] 59.82). Com esta atitude, e ao revelar a simplicidade do seu caráter, Teógenes ganhou a compaixão e a condescendência do Areópago e os seus membros abstiveram-se de o julgar, pois consideraram que ele fora vítima de engano ([D.] 59.83). Como já acontecera nos casos anteriores, Apolodoro apresenta testemunhas. No entanto, o orador refere que a testemunha escolhida, Teógenes, virá de 
forma forçada testemunhar ([D.] 59.84). Ou por ela própria se assumir como uma testemunha relutante por ter de relembrar e reviver uma situação que só lhe trouxera angústia e problemas, ou por Apolodoro saber que o cargo para que Teógenes fora eleito lhe exigia confidencialidade, e saber que não the poderia exigir demasiados pormenores sobre determinados aspetos desse cargo, ou ainda por uma questão de puro artifício retórico (cf. [D.] 59.28 e 53). Como inimigo de Estéfano, não é provável que Teógenes hesitasse em aproveitar uma oportunidade como esta para se vingar. Além disso, não existem meios exteriores ao processo para determinar o grau de autenticidade deste documento, i.e., a prova testemunhal do próprio Teógenes.

Ainda a propósito do episódio de Teógenes, há no discurso de Apolodoro um grande silêncio sobre a investigação levada a cabo pelo Areópago. Este silêncio talvez se deva ao desejo da própria instituição em não deixar transparecer pormenores que poderiam denegrila ainda mais aos olhos da sociedade, já que o seu secretismo fora violado por uma mulher adúltera, daí que houvesse necessidade de preservar as aparências do seu estatuto.

As penas por impiedade eram severas e esta é uma situação extrema. Fano é desqualificada pelo seu nascimento e pelo fato de ter sido basilinna. Estéfano poderia ter sido acusado não só por ter dado em casamento uma estrangeira a um ateniense, mas sobretudo por impiedade. Teógenes tinha então uma oportunidade única para o atacar. Mas o secretismo que 
envolveu os acontecimentos é problemático, mais ainda quando é perspetivado do ponto de vista de sociedades habituadas a ver o segredo como uso e abuso de poder. Não se compreende a impunidade com que é tratado um tão abominável crime, que punha em risco a relação entre a cidade e os seus deuses. Que não atuassem contra Teógenes, vítima da sua própria ingenuidade, era aceitável, mas não havia qualquer motivo para não acusarem Estéfano. Parece, portanto, que esta narração de Apolodoro não era em tudo convincente e náo era suficientemente fundamentada.

Será então a narrativa do caso de Teógenes uma invenção de Apolodoro, como supóe Carey? Aliás, como refere este investigador, estas falhas não seriam de todo evidentes para os jurados que ouviam a narrativa do orador. Contudo, dentro desta suposta invenção da narrativa de Teógenes, Carey é lacunar porque não consegue explicar como é que Teógenes aparece a testemunhar sobre o seu divórcio e sobre a destituição de Estéfano do seu cargo de assessor. ${ }^{19}$

A linha de argumentação aqui defendida segue com fidelidade a de Kapparis. Segundo o referido investigador, Apolodoro não podia obrigar Teógenes, que se mostrava relutante, a testemunhar sobre certos acontecimentos em detalhe, pois nesse caso ele estaria a quebrar a confidencialidade da atuação do Areópago e incorreria ele próprio em várias inconveniências e ofensas. Teógenes podia ser questionado sobre o seu divórcio e a expulsão de Estéfano do seu cargo de

${ }^{19}$ Carey (1992: 127). 
assessor, testemunho, aliás, que o júri estaria à espera na sequência do casamento e do divórcio de Frastor com Fano. Kapparis continua a argumentar que, com o testemunho dos dois anteriores maridos de Fano, Apolodoro náo precisava de mais elementos para convencer o júri de que Fano fora casada duas vezes e que também se divorciara duas vezes.

$\mathrm{O}$ discurso de Apolodoro insere o testemunho de Teógenes. Se este fosse um documento cuidadosamente esboçado que sublinhasse o divórcio e a expulsão de Estéfano do seu cargo, ofereceria apoio suficiente à narrativa e serviria muito bem os objetivos do orador. No entanto, para Kapparis, embora o conteúdo do texto em causa apresente o que era esperado, a sua forma sugere que foi forjado. $\mathrm{O}$ vocabulário utilizado no testemunho de Teógenes apresenta semelhanças alarmantes com a narrativa precedente, o que permite concluir que derivava do contexto anterior. Além disso, o indício mais evidente de falsificação é o estilo repetitivo do documento. ${ }^{20}$

Entramos agora numa outra fase do discurso conducente ao seu epilogo: as provas ([D.] 59.85-125). Apenas um quarto deste conjunto aborda as questóes de fato. Uma primeira fase trata da capacidade de Fano para exercer o cargo de basilinna, e numa segunda é apresentada a refutação dos argumentos de Estéfano.

Tudo o resto visa estimular a hostilidade para com a acusada e para com a sua própria máe, Neera, e

${ }^{20}$ As características do vocabulário podem levar a supor que também o documento apresentado em [D.] 59.54 não seja autêntico. Cf. Kapparis (1999: 276-277, 353). 
encorajar os jurados a tratá-la severamente. A própria extensão desta fase do discurso que é conferida às narrativas descritivas procura, de forma deliberada, fazer nascer um efeito de repulsa contra esta figura feminina, por parte de quem há de decidir.

Apolodoro argumenta a fortiori que Fano não tinha direito a desempenhar o cargo que exerceu, como basilinna, nem tão pouco a entrar em templos, devido aos seus precedentes de adultério, e enfatiza a respetiva punição legal, baseando a sua argumentação na referência à própria lei ([D.] 59.85-87). O interesse maior desta citação é o de evidenciar o detalhe que refere a punição. É neste detalhe que se baseia Carey para supor a autenticidade da lei, pois que é o único que não se pode inferir da versão da lei feita por Apolodoro ([D.] 59.85-86). ${ }^{21}$ Esta situação da punição feminina devido a adultério é, curiosamente, semelhante a outra presente em Ésquines. Esta lei pode ser atribuída a Sólon. Aliás, Ésquines refere Sólon como uma autoridade no tratamento de leis que proibiam a mulher adúltera de usar adornos e de assistir aos sacrifícios públicos (Aeschin. 1.183). E, se a interdição não fosse cumprida, a lei propunha que qualquer um a maltratasse, mas procurando evitar a morte. Quanto ao marido que continuasse a viver com uma mulher adúltera, este seria castigado com atimia.

A lei permitia à mulher estrangeira ou escrava ser espetadora de cerimónias públicas ou fazer uma súplica. As únicas mulheres a quem era vedado o acesso

${ }^{21}$ Carey (1992: 129). 
a santuários públicos eram as adúlteras. Sobre elas qualquer pessoa podia fazer recair um castigo, exceto a morte. Pretendia-se que a lei amedrontasse as mulheres e as mantivesse fiéis guardiãs da casa. Se elas quebrassem esse dever, seriam excluídas da casa dos seus maridos e do culto da cidade. A religiáo era uma área em que a mulher tinha uma presença significativa e os festivais religiosos representavam as raras ocasióes em que a mulher deixava a casa.

Em seguida, Apolodoro prossegue com a afirmação da importância de se ser cidadão ateniense e de se ser reconhecido como tal, e do dom que é chegar a sê-lo. Explica à audiência os procedimentos conducentes à naturalização de estrangeiros, fazendo com que saísse realçada a ofensa que tinha constituído o ato abominável de Estéfano, quando usurpara esse estatuto. $\mathrm{O}$ voto de concessão de cidadania era atribuído aos benfeitores da cidade, e era confirmado em Assembleia por mais de seis mil atenienses que votavam em segredo ([D.] 59.89). A lei interditava algumas funçóes ao novo cidadão, como ser nomeado para o conjunto de nove arcontes e participar em qualquer sacerdócio. Só aos seus descendentes era conferida a integridade dos direitos de cidadania, mas sob condiçôes (cf. [D.] 59.104).

Para ilustrar esta questão e, sobretudo, para confirmar o valor de se ser cidadão ateniense, o orador vai evocar um exemplo histórico que remonta ao passado. Nesta altura em que Atenas vivia a ameaça constante dos Macedónios, os Oradores recorriam com frequência à 
evocação dos grandes momentos da sua glória histórica. ${ }^{22}$ Trata-se de uma longa digressão narrativa sobre os Plateenses e a sua fiel aliança com Atenas, durante as Guerras Pérsicas ([D.] 59.94-106). Os Plateenses, que combateram ao lado dos Atenienses em Maratona, mais tarde defrontaram os Persas em Plateias, onde a armada persa foi derrotada em 479 a.C. Segue-se ainda a narração do diferendo entre Plateenses e Lacedemónios, que pretendiam fazer aqueles renunciarem à aliança com Atenas e os levaram a resistir-lhes praticamente até à exaustão ([D.] 59.101-103).

Em sinal de reconhecimento do auxílio sempre prestado, os Atenienses passaram a conceder-lhes o estatuto de cidadania. É a este propósito que Apolodoro cita o decreto sobre os Plateenses ([D.] 59.104), que, mesmo assim, só seria aplicado depois que um exame individual fosse elaborado previamente em tribunal. Mas um Plateense que não tivesse sido naturalizado naquela ocasiáo, ficaria impedido de o fazer mais tarde, por forma a impedir que se obtivesse fraudulentamente esse direito.

${ }^{22}$ Por diversas vezes se verifica que o conhecimento histórico dos Oradores dos séculos V e IV a.C. é limitado, mesmo quando se trata de períodos próximos deles. Contudo, essas referências eram suficientes, visto que se dirigiam a um auditório formado essencialmente por homens do povo. Por exemplo, a nomeação dos nomes de Drácon e de Sólon por parte dos Oradores, ainda que brevemente e raras vezes, pretendia dar um cariz de importância legal ao exposto. Além disso, os Oradores baseavam os seus argumentos em legislação sua conhecida ou que era utilizada naquela época. Sobre o aproveitamento da história pelos Oradores Áticos, vd. Carey (1992: 132-140). O exemplo mais famoso de evocação histórica é o que ocorre em De Corona, D. 18.208. 
Apolodoro aproveita então, depois deste longo excurso, para comparar o caso exemplar dos Plateenses, cuja recompensa pela sua lealdade e auxílio estava sujeita a condiçóes, e o caso de uma mulher que exerceu a prostituição em toda a Hélade. $\mathrm{O}$ cenário que deve ser afastado é o de Neera acabar por ficar impune, a despeito das ofensas à cidade e aos deuses, ela que não era ateniense por nascimento, nem cidadã por decreto do povo ([D.] 59.107).

$\mathrm{O}$ orador lança diversas perguntas retóricas ao seu auditório com vista a argumentar de forma mais enérgica e eficaz contra a clemência que pudesse vir a recair sobre Neera; e apela mesmo ao temor religioso para o caso de ela não ser castigada ([D.] 59.109).

Em seguida, o orador lança novas questóes aos jurados relacionadas diretamente com as suas familiares femininas. Chega mesmo a solicitar aos jurados que se coloquem na posição em que terão de explicar às suas mulheres, esposas, filhas ou mães, o resultado do que tinham deliberado a respeito deNeera ([D.] 59.110-111). Este passo permite ainda melhor compreender aspetos importantes do quotidiano masculino e feminino: a convivência, a troca de ideias e informaçóes sobre as relaçóes diárias dos membros do oikos. Ao regressar a casa, um cidadão conversava naturalmente com as mulheres com quem partilhava o oikos, sem restriçóes aparentes, sobre questóes que o tinham ocupado durante a atividade do seu dia.

Este momento do discurso Contra Neera coloca uma questão importante na análise da história 
feminina em Atenas. Quais seriam as características do relacionamento entre um homem e as suas parentes femininas? A mulher, esposa de um cidadão, era um ser habitualmente afastado da atividade política, judicial e comercial e, por isso, dependia do marido para o conhecimento do mundo da polis. Nesta passagem do texto de Apolodoro verifica-se que a curiosidade feminina é prontamente satisfeita, o que revela que muitos Atenienses estavam habituados a repartir as suas experiências quotidianas com as mulheres. Uma atitude semelhante é referida em Licurgo (Lycurg. Leoc. 141), em que o orador convida os que estáo a julgar Leócrates por traiçáo que anunciem aos seus filhos e mulheres que o castigaram pelo seu ato. Neste convite subentende-se, obviamente, que os filhos e as mulheres se encontram em casa. Parecia ser comum que os homens comentassem a sua atividade no exterior junto da família.

Perante a absolvição da conduta de Neera, as mulheres honestas hão de sentir-se revoltadas, vendo que os seus direitos na cidade e nos sacrifícios religiosos tinham sido alargados àquele tipo de mulher. Quanto às que eram néscias, tal impunidade permitia-lhes a licenciosidade. As leis seriam impotentes e as heteras seriam livres de fazer o que desejassem.

Apolodoro chama a atenção para o problema que esta situação colocava às filhas dos cidadãos pobres. As jovens mulheres que eram filhas de cidadáos pobres não teriam facilidade em encontrar maridos, se as meretrizes tivessem direito de casar com quem quisessem e de mentir sobre a identidade dos próprios filhos. Quando 
as jovens se encontravam em dificuldade financeira, a lei previa a atribuição de um dote suficiente para resolver essa situação (cf. [D.] 59.113). A referência ao dote destinava-se a reforçar o contraste entre Neera e as mulheres legítimas, pois ele representava um direito exclusivo de uma mulher nascida de pais cidadáos ao casar com um cidadão ateniense.

Prestes a finalizar, Apolodoro apela ao respeito pelas leis, pois é a defesa da própria família de cada jurado que está a ser ameaçada. A absolvição de Neera levaria à subversão das leis, o que para os Atenienses era algo de contraditório, já que eles eram orgulhosos da sua obediência a um código que governava a cidade (cf. [D.] 59.115).

Como refere Apolodoro, há já um precedente que pode ser usado na resolução deste caso: trata-se de Árquias. Este é um exemplo de violação religiosa em Elêusis. Árquias havia imolado uma vítima para a hetera Sinope numa altura em que não era permitido fazer sacrifícios. Ora, porque parecia que Árquias havia transgredido uma das normas tradicionais e cometera injustiça, ele teve de pagar a sua culpa. E de nada lhe valeram as súplicas dos seus parentes, dos seus amigos, as liturgias que pessoalmente havia prestado à cidade e os seus antepassados, nem mesmo o fato de ser hierofanta. Interroga-se então o orador quanto a Neera, que tinha cometido impiedade contra esse mesmo deus, sobre se ela ficaria impune ([D.] 59.117).

Este caso também é selecionado pelos pontos de contato com o atual assunto em discussão: a identidade 
do deus insultado e o envolvimento de uma cortesá. Claro está que nenhum júri se deixava influenciar pela decisão de outro júri, mas os precedentes tinham um valor persuasivo. Já a menção anterior do caso dos Plateenses ia no mesmo sentido.

Por último, Apolodoro antecipa aquela que seria, com toda a certeza, a defesa de Estéfano. Este refutaria que Neera fosse sua mulher, mas apenas sua hetera. As crianças não seriam dela, mas de uma ateniense, que ele teria desposado anteriormente ([D.] 59.119).

Para refutar esta defesa fraudulenta, Apolodoro teria que recorrer a testemunhos que revelassem a verdade. Caso se provasse, através da tortura das escravas que tinham trabalhado para Estéfano e Neera, que Estéfano teria realmente desposado uma ateniense e dela possuísse descendentes, ele próprio renunciaria à acusação ([D.] 59.119-121, 124). Só que nesta referência Apolodoro esqueceu-se de que o principal acusado não era Estéfano, mas Neera.

O epílogo nada traz de novo, a não ser a reafirmação veemente de desejo de vingança e a insistência no aspeto religioso do processo. Por isso se pede a punição merecida para aqueles que, ao usurparem os seus direitos, ofenderam os deuses ${ }^{23} \mathrm{e}$ desvalorizaram o prestígio da cidadania e o poder do demos. A acusação centra-se por fim sobre Neera que, sendo estrangeira, vive matrimonialmente com um cidadão ([D.] 59.126).

${ }^{23}$ Apolodoro deve estar a pensar nâo só em Dioniso, mas também nos outros deuses que foram adorados pela família e fratria de Estéfano. Vd. Carey (1992:151). 
Este excesso de precisão de dados na parte final do texto atenua o que poderia ter sido uma conclusão sóbria, incisiva e muito mais convincente. Será que Apolodoro não tinha apenas a intenção de denegrir a imagem pública desta mulher com vista a obter efeitos práticos e retóricos? Ou será que o fez para a usar como um exemplo a não seguir junto das outras mulheres? A liberdade de Neera, a sua astúcia, a sua paixão pela vida fácil não terão suscitado ciúme e inveja femininas?

A tradição não transmitiu o resultado deste discurso, lacuna que leva a estas diversas hipóteses na reconstrução racional dos argumentos de Apolodoro.

Se Neera fosse culpada, poderia ser vendida como escrava e Estéfano perderia o seu património e os seus direitos cívicos por completo (cf. [D.] 59.52). Se Neera não fosse condenada, o valor de cidadania da mulher ateniense seria diminuído, pois bastaria o casamento com um cidadáo para ver reconhecido esse direito. Ao mesmo tempo, não se pode esquecer que um crime deve ser punido casual e individualmente, e não como forma de exemplo.

Depois de todos estes dados do processo judicial, que ideias de força ficam após uma leitura detalhada de Contra Neera?

Apolodoro mostra um grande interesse pela profusão de pormenores e provas factuais com vista a evidenciar o percurso biográfico de Neera e da sua filha Fano, que seguiu de perto os passos da mãe. A despeito de ser parte interessada no veredito do julgamento, mostra como aspetos políticos, sociais e religiosos devem coabitar harmoniosamente de forma 
a defender e assegurar o correto funcionamento da democracia ateniense. Em ordem à realização deste objetivo, Apolodoro parece aconselhar a que a noção de cidadania seja realizada com rigor e que os constantes desrespeitos à lei pública sejam punidos. Neera deve ser punida também porque usurpou o privilégio feminino no mundo dos ritos, ultrajando assim o importante papel que a mulher aí tinha.

O interesse privado no veredito final não parece ser suficiente, porém, para justificar a atenção detalhada aos eventos da vida de Fano. É difícil compreender como é que a descrição pormenorizada da biografia dessa mulher poderia favorecer o caso do orador. Devido à sinuosidade da vida da filha de Neera, pode considerar-se implausível o percurso táo acidentado de Fano. O primeiro casamento com Frastor, depois o escândalo público do divórcio e ainda um outro escândalo por causa do estatuto da criança nascida daquela uniáo; em seguida, a acusação fraudulenta de adultério contra Epéneto de Andros; e ainda, depois de tudo isto, o engano lançado a um homem de boa família como Teógenes, que não tinha conhecimento do passado de Fano e que julgava que ela fosse uma cidadã ateniense.

É bem provável, pois, que a biografia de Fano possa náo corresponder à verdade e tratar-se de uma criação deliberada de Apolodoro, revelando-se um trabalho de argumentação bem conseguido. Se esta linha de interpretação for aceitável, os ouvintes deste discurso no tribunal e os leitores posteriores desta peça oratória estariam perante uma descrição do feminino que poderia 
ser eventualmente verdadeira em cada uma das suas partes, mas não ser verdadeira enquanto descrição da mulher Fano, em particular. Como as peças oratórias de índole privada estão ao serviço de interesses privados, é aceitável que o exagero hiperbólico esteja presente em algumas descriçóes. Alguém que tivesse reclamado em tribunal um dano, é provável que amplificasse esse dano. Dentro deste ponto de vista, a biografia de Fano seria um exemplo deste processo geral de exagero hiperbólico. Os eventos da biografia de Fano não poderiam ser apresentados em tribunal de um modo demasiado implausível, mas é do interesse do orador que fossem exagerados. Um ponto interessante que permanece por esclarecer é o de saber onde é que o orador teria ido buscar a informação para construir os eventos de uma vida tão atribulada. Deste ponto de vista, a biografia de Fano parece ser mais literária do que jurídica, se bem que esteja ao serviço de um processo jurídico.

Todavia, parece que Contra Neera, discurso inflamado de emoção e moralidade, visa um assunto de índole privada em que os argumentos e justificaçóes assentam na ordem judicial e pública da Atenas contemporânea do domínio macedónio. Através de pormenores ofensivos aos costumes, pretendia-se um exagero retórico que denegrisse a imagem pública de um homem cuja vida privada se conduzia por desvios constantes à lei e boa conduta de um cidadáo ateniense. A independência e liberdade de Neera contrastavam com a dependência de outra qualquer mulher, filha ou esposa de cidadão. Fazendo uso da retórica, dá-se a 
conhecer os bastidores da vida agitada de uma mulher de vida fácil.

A eventual absolvição de Neera, e a chamada de atenção para esta hipótese que é feita por Apolodoro, advertia as outras mulheres para uma liberdade que podia afinal ser alcançável por um maior número delas. Este fato podia levá-las à tomada de consciência de uma possibilidade latente para toda a mulher que não fosse nem escrava, nem liberal ao ponto de praticar a prostituição. Essa possibilidade parece ter sido, contudo, subvalorizada pelos homens e mulheres de Atenas.

A posição social de Neera torna-se um privilégio em relação ao estatuto atribuído à mulher em geral. Essa posiçáo valoriza a sua existência feminina pondo-a em contacto direto com o sexo oposto e mostrando-lhe um mundo de convívio, de conhecimentos e de influências que seria impossível com outro estatuto, por exemplo, aquele que era limitado pelas disposiçóes sociais próprias de uma esposa, mãe ou filha.

\section{ApresentaÇáo do Discurso}

O presente discurso tem duas partes distintas. A primeira, compreendendo os parágrafos $1-15$, é proferida por Teomnesto; a segunda, dos parágrafos 16-126, é pronunciada por Apolodoro. É Teomnesto quem apresenta a acusação, mas devido à sua inexperiência e à sua falta de capacidade legal ele solicita a presença do seu parente Apolodoro para o auxiliar a conduzir o caso. Apolodoro é o synegoros, isto é, a pessoa que fala em tribunal a favor do litigante. A parte por si pronunciada é a synegoria. 
Todos estes aspetos estão de acordo com a lei ateniense. Um homem podia ele próprio apresentarse em tribunal, à exceção dos menores e das mulheres que tinham de ser representados pelo seu tutor ou responsável, o kyrios. Se um homem se encontrasse doente ou fisicamente indisponível para conduzir o seu próprio caso, podia solicitar a um amigo que estivesse presente para o auxiliar nessa tarefa representativa. No entanto, isto não queria dizer que fosse o orador, portanto aquele que proferia o discurso, que tinha de escrever o seu próprio discurso. Era habitual existir um logógrafo profissional para elaborar o discurso que, depois, o litigante pronunciava em tribunal.

\section{Procedimento Judicial}

Qualquer caso legal era designado por graphe, e a acusação podia ser feita por um cidadão ateniense, ho boulomenos, que estivesse na posse de todos os seus direitos cívicos, isto é, que não tivesse sido atingido por atimia. $\mathrm{O}$ acusador devia proceder a uma notificação ou uma citação formal (prosklesis ou klesis) junto do réu na presença de pelo menos uma testemunha (kleter) para comparecer diante do órgáo competente num determinado dia, neste caso particular os tesmótetas, como a lei estabelecia. Se a acusação se dirigisse a uma mulher, ela devia ser notificada juntamente com o seu kyrios, visto que as mulheres não podiam conduzir o seu processo legal. Era o kyrios que assegurava a sua representatividade, assim como no caso de menores de idade. $\mathrm{Na}$ situaçáo em que eram estrangeiros os 
acusados, eles podiam solicitar apresentar uma caução ou uma garantia para poderem comparecer em tribunal; se eles não conseguissem apresentar uma delas, ficavam detidos para prevenir que abandonassem Atenas.

A situação legal que, com alguma probabilidade, motivou este discurso foi uma graphe xenias. Este procedimento judicial trata essencialmente da usurpação dos direitos de cidadania por parte de alguém que não tinha direito a exercê-los, como um xenos ou um estrangeiro. Se este caso cobria exclusivamente a situação de uma graphe xenias, é difícil de provar. Uma graphe xenias abrangia ou o filho de dois pais estrangeiros em que ele próprio se tinha inscrito na fratria ou no demo, ou o filho de um casamento entre ateniense e estrangeiro, em que ele próprio se apresentara como um cidadão, ou um nothos, ou ainda o filho de um escravo. Nestas quatro situaçóes, aquele que era alvo de acusação teria conseguido inscrever-se num demo ou numa fratria, e pelo fato de o seu nome constar da lista do demo fazia com que ele próprio se pudesse apresentar e ser considerado como cidadáo perante a sociedade em geral. As mulheres não eram inscritas nas listas do demo. A sentença por condenação por uma graphe xenias podia ser ou a morte e a confiscação de propriedade, ou a venda para escravatura e a confiscação de bens, ou somente a privação de direitos e a confiscação de bens. No entanto, para o caso particular de Neera, não se dispóe de muita informação que permita especificar a que situação se referia, o que não fará grande diferença ao que verdadeiramente importa. Isto é, o que verdadeiramente importa revelar e confirmar é que 
Neera usurpou um direito cívico limitado aos cidadãos atenienses que era contrair um casamento com um cidadão ateniense. A diferença entre este processo sobre Neera e um caso de graphe xenias, daquilo que se sabe sobre ele, é que neste último apenas o xenos era punido. Nesta graphe, agora em análise, ambas as partes envolvidas no casamento ilegal são objeto de punição: Neera será vendida para escravatura, assim como alguns bens pessoais de que ela fosse proprietária também seriam vendidos; quanto a Estéfano, seria multado em mil dracmas (cf. [D.] 59.16).

No caso da graphe xenias, num determinado dia, hene kai nea, a acusação formal (graphe) era entregue à entidade competente e eram pagas as taxas legais, se as houvesse. Em algumas graphai, incluindo a graphe xenias, as custas exigidas, parastasis, no momento em que a acusação era feita, eram pagas por quem apresentava a acusação. Desconhece-se qual o montante deste tipo de taxa, e se terá sido pago no caso particular de Neera. Passados uns dias, a instituição à qual tinha sido dirigida a acusação orientava a audiência preliminar (anakrisis), momento em que o acusador e o acusado tinham de comparecer. Ao mesmo tempo, os magistrados decidiam se esta graphe devia ou não ser julgada, e estabelecia-se a data para o julgamento perante o tribunal adequado àquela causa, dikasterion. As duas partes eram ouvidas diante do tribunal. $\mathrm{O}$ kyrios da mulher falava em seu nome. Entáo o júri estava pronto para votar. Neste caso particular não era necessário um segundo voto, visto que o castigo era fixado por lei, agon timetos. 
Neste caso particular, a acusação dirige-se diretamente contra Neera, sobretudo, e segundo o ponto de vista do acusador, porque ela não era uma cidadá. Esta situação podia apresentar problemas processuais complicados. Se Neera não estava legalmente habilitada a estar casada com Estéfano, entáo, para todos os efeitos, Estéfano não devia ser do ponto de vista legal o seu kyrios, nem tinha o direito de conduzir os seus assuntos legais. $\mathrm{O}$ aspeto mais importante deste processo é o fato de que não havia forma de provar que Neera era uma cidadá; todos os momentos da sua vida até aí indicavam, aliás, o contrário. É possível imaginar que um outro processo teria acontecido e antecedido a atual graphe. Podia ter acontecido que Teomnesto tivesse tentado levar Neera diante dos poletai, vendedores públicos de bens confiscados, com intenção de a vender como escrava visto que ela era uma estrangeira, ou visto que ela era uma escrava que usufruía indevidamente de direitos civis; em consequência disso, Estéfano ter-se-ia oposto a esse arrastamento até aos magistrados apropriados, isto é, uma apagoge, e um júri para o processo tornar-se-ia necessário. Contudo, nenhuma apagoge é mencionada ou indiciada ao longo do discurso, e a lei enunciada no parágrafo 16 não exige nem presume qualquer procedimento judicial preliminar.

Assim, a presença de Estéfano a representar Neera tem várias interpretaçóes. Até ser provado o contrário, ela era considerada sua mulher; portanto, para todos os efeitos legais, ele era o seu kyrios e devia representá-la. $\mathrm{O}$ mesmo se aplicaria se Neera tivesse o estatuto de pallake 
(concubina); neste caso, ele continuava a ter o papel de kyrios (cf. D. 23.53; Plut. Sol. 23.1). Uma mulher tinha sempre de recorrer a um homem para se apresentar em tribunal e defender o seu caso, quer fosse ateniense ou estrangeira. $\mathrm{Na}$ ausência de provas, o homem em casa de quem a mulher vivia seria tido como o seu kyrios. Diversos são os momentos do discurso em que é feita referência à presença de Neera em pessoa durante o julgamento e ao facto de ser Estéfano quem conduziu a sua defesa.

\section{Do Discurso ao Veredito}

Como acontece na maioria dos casos a que se reportam os discursos privados que chegaram até hoje, desconhece-se o veredito no caso contra Neera.

Náo se deve esquecer que apenas dispomos de um dos lados do caso, isto é, o lado correspondente à apresentação da acusação. Alguns fatos podem ter sido materialmente diferentes e divergir da forma como aparecem descritos e mencionados no discurso. Para confirmar estes aspetos, deve notar-se que nem todas as declaraçóes são apoiadas por testemunhas; algumas observaçóes podem ser inverosímeis.

Era fácil conseguir que alguém testemunhasse a confirmar as falsas declaraçóes do orador ${ }^{24}$ e até era possível para um litigante interpretar as leis existentes de maneira distinta daquela que originalmente elas

${ }^{24}$ Para esta situação precisa existia um procedimento judicial que correspondia a uma açáo por falso testemunho, dike pseudomartyrion. 
tinham sido pensadas, ou mesmo citar, como suporte jurídico para o seu caso, uma lei que não existia. ${ }^{25} \mathrm{~A}$ probabilidade de deturpação dos fatos por parte de qualquer um dos litigantes, assim como a ausência de informação independente por parte da defesa de Estéfano, deve alertar o leitor para o fato de que nem tudo o que é declarado corresponder à verdade.

Alguns académicos têm referido que Estéfano, com a sua habilidade e experiência em assuntos legais, pode ter conseguido fazer uma defesa muito boa de forma a garantir o sucesso do caso, como aponta Apolodoro nos parágrafos 118 e seguintes. Mas a verdade é que algumas das perguntas retóricas e sentenças deixadas nos parágrafos 109-111, sobre a forma como a população em geral reagiria se soubesse que o caso de Neera e do seu companheiro havia de sair impune daquele tribunal, podem ser consideradas como um desafio lançado ao júri. É bem provável que a decisão do tribunal tivesse sido a da condenação de Neera.

${ }^{25}$ Esta devia ser uma situação rara, mas que podia acontecer, como se pode verificar por um discurso pertencente ao Corpus Demosthenicum, [D.] 26.24, em que se menciona a possibilidade de alguém que apresentou uma lei inexistente ver aplicada a pena de morte como castigo. 
Contra NEERA 
(Página deixada propositadamente em branco) 


\section{Assunto $^{1}$}

1. Julgam que este discurso não pertence a Demóstenes, porque é simples e, muitas vezes, inferior ao talento deste orador. Tem o seguinte argumento. Se uma estrangeira casasse com um ateniense, ordenava a lei que ela fosse vendida; Teomnesto, segundo essa lei, refere-se a Neera, dizendo que ela casou com Estéfano, que tinha sido escrava de Nicareta e fora hetera anteriormente; porém agora está casada com Estéfano, conforme a lei, e tem filhos dele. Mas Estéfano não está de acordo com isso, ao contrário, afirma que convive com ela, 2. mas como hetera e não como esposa, e afirma, ainda, não ter filhos dela. $\mathrm{O}$ acusador, opondo-se justamente a tudo isso, fornece não poucas provas de que ela convive na qualidade de esposa. Na verdade,

${ }^{1} \mathrm{O}$ argumento é da autoria de Libânio. A obra de Libânio de Antioquia (314-393 d.C.) Hyphoteseis ton logon Demosthenous terá sido escrita por volta de 325 em Constantinopla, compreende uma biografia de Demóstenes (que se encontra incompleta), assim como cinquenta e sete argumentos dos discursos que o orador terá escrito. Libânio tornou-se num retor e sofista famoso grego que devido às suas qualidades foi mestre de João Crisóstomo, Amiano Marcelino e provavelmente de Basílio de Cesareia, entre outros. Foi um escritor profícuo. Mais de mil e seiscentas cartas da sua autoria sobreviveram e através delas é possível recolher com pormenor e fidelidade informação relativa à sua época. Libânio, neste argumento ao discurso [D.] 59 que agora se apresenta, pretende evidenciar que, segundo a acusação, Estéfano e Neera estavam a viver como se estivessem casados legalmente. 
a contestação do discurso torna-se conjectural, pois a investigação versa sobre uma realidade e não sobre uma particularidade nem sobre uma qualidade. Teomnesto pronuncia as primeiras partes do discurso, em seguida chama como defensor Apolodoro, que é seu cunhado, mas é Teomnesto quem dá andamento ao processo.

(1) Atenienses, para eu intentar esta ação pública contra Neera e comparecer diante de vós, inúmeras foram as provocaçóes. $\mathrm{Na}$ verdade, nós fomos muito prejudicados por Estéfano e, por causa dele, fomos expostos a extremos perigos, não só meu cunhado, eu próprio, minha irmá e minha esposa, de modo que estou sustentando o presente processo, não me defendendo, mas vingando-me. De fato, ele começou em primeiro lugar essa desavença, não tendo jamais sofrido nenhum prejuízo de nossa parte, nem por palavras, nem por açóes. Quero expor-vos primeiramente todas as coisas que sofremos por causa dele, a fim de que me perdoeis, porque estou me defendendo, e, ainda, quero expor-vos como nós fomos expostos a extremos perigos em relação a nossa pátria e ainda quanto à perda da cidadania.

(2) Com efeito, quando o povo ateniense decidiu ser Pásion e também seus filhos cidadãos atenienses, por causa dos serviços prestados à cidade, meu pai ficou de acordo com o benefício do povo e deu em casamento a Apolodoro, filho de Pásion, uma sua filha, minha irmá, com quem Apolodoro tem filhos. Ora, sendo Apolodoro prestimoso em relação a minha irmã e a vós todos e considerando que os que são verdadeiramente 
da família participam de todos os bens, eu tomei como esposa a filha de Apolodoro, também minha sobrinha.

(3) Com o passar do tempo, Apolodoro foi designado por sorteio membro do Conselho. ${ }^{2}$ No momento em que foi aprovado e pronunciou o juramento legal, ocorreu na cidade uma guerra, durante a qual era possível para vós, ou, em caso de vitória, vos tornardes os mais poderosos dos Helenos e, incontestavelmente, retomardes dos inimigos os vossos bens, e também vencerdes Filipe, ou então, se tivésseis chegado tarde com o socorro e abandonado os vossos aliados e, por falta de recursos, o exército fosse dispersado, vós perderíeis os vossos aliados e, para os outros Helenos, pareceríeis ser desleais e correríeis perigo em relação aos restantes dos aliados, não só em Lemnos, em Imbros, em Ciros e no Quersoneso. ${ }^{3}$ (4) E estando vós, em

${ }^{2}$ Neste passo, faz-se alusão ao procedimento habitual de seleção dos elementos do Conselho dos Quinhentos (cinquenta por tribo), que era feito por sorteio. Todos os anos quinhentos homens eram designados à sorte, de entre os cidadãos atenienses, para serem seus membros. Tinham de ter idade acima dos trinta anos e não podiam ser considerados incapazes por qualquer razáo. Os escolhidos por sorteio realizavam um exame de moralidade, ou docimasia, conduzido pelos membros do Conselho cessante. Quanto ao conteúdo do juramento, variou ao longo dos tempos.

${ }^{3} \mathrm{O}$ orador refere-se ao ano de 348 a.C, data em que Olinto foi tomada por Filipe, pois este já a havia cercado em 349. A crise nos assuntos de Atenas a que Teomnesto se refere desenvolveuse quando os Atenienses começaram a perceber a extensão e os perigos do poder de Filipe. Durante os anos de 351-349, Filipe foi atacando as ilhas de Lemnos e de Imbros, membros da Segunda Confederação Ateniense que já tinham sido palco de conflito, cinco ou seis anos antes durante a revolta que envolvera outras ilhas aliadas de Atenas. Mas ele também foi realizando operaçóes militares em Híeron Teichos, perto do Quersoneso, para grande preocupaçáo 
massa, a ponto de marchar para Eubeia e Olinto, Apolodoro, como conselheiro, propôs um decreto no Conselho e levou o projeto para a Assembleia. ${ }^{4}$ Referia o projeto que o povo votaria, levantando as máos, se fosse conveniente que o dinheiro excedente das despesas fosse dos fundos militares ou fosse dos fundos de espetáculo, já que as leis ordenavam que, quando houvesse guerra, o dinheiro excedente fosse dos orçamentos militares. Mas Apolodoro, pensando que era preciso o povo ser soberano com relação a seus interesses, pretendia realizar tudo aquilo, jurando decidir da melhor forma possível para o povo ateniense, como todos vós fostes testemunhas naquela ocasião. (5) De fato, quando se realizou a votação, ninguém se opôs a que não se devesse utilizar esses fundos da guerra, mas ainda hoje, em algum lugar em que seja proferida uma palavra sobre isso, é reconhecido por todos que, tendo ele proposto a melhor resolução, foi punido injustamente. Portanto, os juízes

dos Atenienses. Ao mesmo tempo, também Olinto, que se tinha aliado a Filipe, estava a procurar ajuda de Atenas contra ele. Esta situação vai levar Demóstenes a escrever as Olínticas, na qual se promove uma ação vigorosa para libertar Olinto. Em Eubeia, Plutarco de Erétria, um aliado de Atenas, tinha solicitado auxílio contra os seus oponentes numa revolta popular, e, em Fevereiro de 348, uma força foi enviada sob o poder de Fócion. Depois de várias contrariedades, mas também de alguns reforços, esta campanha terminou em derrota. Entretanto, são necessários fundos urgentes para a expediçáo a Olinto. É este problema que Apolodoro aborda na sua proposta, apresentada no parágrafo 4 .

${ }^{4}$ Uma das principais funçóes da boule era preparar a agenda para os encontros da ekklesia. Para que um assunto fosse discutido, retificado, contra-argumentado e votado na ekklesia, era necessário que antes os membros da boule apresentassem um probouleuma, ou um projeto de decreto. 
irritaram-se com razáo com aquele que os enganou com esse discurso e não com aqueles que foram enganados. De fato, este Estéfano aqui presente, tendo atacado o decreto como ilegal, tendo comparecido diante do tribunal e apresentado, mediante calúnia, falsos testemunhos de que Apolodoro era devedor do Estado há vinte e cinco anos, enfim, fazendo muitas acusações fora do processo, fez condenar o decreto. (6) Se parecia conveniente a Estéfano realizar isso, nós não levamos isso a mal. Mas quando os juízes votavam acerca da penalidade, apesar de nós pedirmos, ele não queria transigir, ao contrário, estimou a pena em quinze talentos, a fim de que os juízes o privassem de seus direitos cívicos, e também os filhos de Apolodoro, minha irmã e ainda nós todos, e nos pusessem na mais profunda miséria e carência de tudo. (7) De fato, por um lado, a fortuna dele náo era sequer de três talentos, de modo que não era possível pagar tal multa. Por outro lado, náo sendo saldada essa multa na nona pritania, ela seria dobrada, e Apolodoro inscrito como devedor de trinta talentos para com o Estado. Depois que foi inscrito como devedor público, a fortuna de Apolodoro ia ser confiscada e tornar-se do Estado, e, quando ela fosse vendida, ele próprio, seus filhos, sua esposa e nós todos íamos entrar na mais profunda miséria. ${ }^{5}$ (8) E, ainda, a outra filha dele ia ficar solteira; na verdade, quem receberia uma sem dote de um devedor do Estado e de um arruinado? Portanto, ele tornou-se o autor de males muito grandes, não tendo

5 Uma situação semelhante é descrita em Contra Nicóstrato, [D.] 53.2. 
jamais sofrido injustiça de nossa parte. Sem dúvida, eu devo muita gratidão aos juízes que pronunciaram o julgamento naquela época, porque não permitiram que Apolodoro fosse espoliado, mas impuseram-lhe uma multa de um talento, de modo que foi possível, com muita dificuldade, pagar a dívida; assim, nós cuidamos de pagar a Estéfano exatamente com a mesma moeda. (9) Com efeito, Estéfano não só procurou destruir-nos desse modo, mas ainda quis banir Apolodoro da pátria. De fato, Estéfano, tendo intentado contra ele uma falsa acusação de que espancara uma mulher - quando, certa vez, Apolodoro foi a Afidna para buscar um seu escravo fugitivo - e de que a criatura morrera do golpe, depois de ter subornado escravos e ter tratado de demonstrar que eles eram habitantes de Cirene, pronunciou contra ele a interdição por homicídio diante do Paládio. ${ }^{6}(10)$ E este Estéfano aqui presente sustentava a acusação, jurando que Apolodoro matara a mulher com as próprias mãos, afirmando, com imprecaçôes contra ele mesmo, sua raça e sua casa, o que não aconteceu, o que ele não viu nem ouviu jamais de indivíduo algum. Mas ele,

${ }^{6}$ A referência aos habitantes de Cirene parece pouco pertinente. Pode tratar-se de um erro na transmissão dos manuscritos; vd. Whitehead (2006: 317-321). Há alguns aspetos a respeito deste homicídio que não são suficientemente esclarecedores. Por exemplo, náo se sabe ao certo qual era o estatuto da mulher assassinada. Pelo fato de a questão ter sido levada ao Paládio, antigo santuário de Palas, deduz-se que a vítima era escrava, porque era um tribunal, de acordo com Arist. Ath. 57.3, que julgava os casos em que uma pessoa era acusada de matar um escravo, um meteco ou um estrangeiro. $\mathrm{O}$ fato de náo se saber se uma morte foi intencional não era suficientemente importante para ser julgado pelo Areópago; vd. MacDowell (1966: 60-69). 
Estéfano, tendo sido reconhecido culpado por jurar em falso e por intentar uma falsa acusação e, ainda, tendose tornado claro que ele fora comprado por Cefisofonte e Apolófanes para expulsar Apolodoro ou para privá-lo dos direitos de cidadão e tendo obtido poucos votos da parte dos Quinhentos, ${ }^{7}$ saiu do tribunal como perjuro e perverso.

(11) Juízes, examinai vós mesmos, raciocinando com base nas probabilidades, como é que eu me arranjaria comigo mesmo, com minha esposa e minha irmá, se alguma coisa acontecesse para Apolodoro sucumbir, por causa de tudo aquilo que Estéfano, aqui presente, conspirou contra ele, quer no primeiro, quer no segundo processo? Ou em que desonra e em que desgraça eu não teria caído? (12) Depois de todos me incentivarem e se apresentarem particularmente a mim, entreguei-me à vingança, por causa de todas as coisas que sofremos da parte de Estéfano; e depois de todos me censurarem, eu seria o mais covarde dos homens se, tendo relações familiares com eles, eu não procurasse vingar aquelas coisas em favor de minha irmã, de meu cunhado, de minhas sobrinhas e de minha própria

7 Neste passo, Carey (1992: 21, 33, 90-91) e Kapparis (1999:187) adotam uma outra liçấo, seguindo a opinião da maior parte dos manuscritos, que acrescenta 'dracmas'à palavra 'quinhentos': «ele recebeu apenas alguns votos apesar de um gasto de quinhentas dracmas». Com esta versão, o texto quer evidenciar que Estéfano terá gasto quinhentas dracmas a subornar testemunhas e talvez também jurados. Segundo Carey e Kapparis, o assunto está relacionado com a questão sobre se os ephetai ou os heliastai eram juízes no tribunal do Paládio em meados do séc. IV a.V. Esta justificação liga-se de forma consuetânea ao que fora mencionado por Teomnesto no parágrafo imediatamente anterior. 
esposa, e se eu não trouxesse diante de vós aquela mulher que é publicamente impiedosa para com os deuses, que é insolente com a cidade e que despreza as vossas leis. Se eu vos tiver convencido, com o meu discurso, de que ela cometeu erros, eu apresentarei aos senhores o argumento que quiserdes utilizar contra ela. (13) E da mesma forma que este Estéfano aqui presente tentava privar-me de meus familiares, contrariamente às vossas leis e aos vossos decretos, assim também eu vim para demonstrar, diante de vós, que ele, contra a lei, casou com uma mulher estrangeira, introduziu crianças entre os membros de sua fratria e de seu demo, deu em matrimônio, como se fossem suas, as filhas de heteras, cometeu uma impiedade para com os deuses e, ainda, despojou o povo de seus direitos, de tornar cidadão qualquer um que ele desejasse. $\mathrm{Na}$ verdade, quem ainda se esforçaria para obter do povo essa recompensa, que exige tantos gastos e tantos esforços, estando na iminência de tornar-se cidadão, quando é possível, com muito menor dispêndio, obter da parte de Estéfano - se é que isso mesmo lhe será permitido?

(14) Consequentemente, eu fui o primeiro a propor essa ação pública, pelo fato de ter sofrido da parte de Estéfano todas aquelas coisas que acabei de vos dizer: que esta Neera, aqui presente, é estrangeira, que está casada com este Estéfano aqui e que violou extremamente as leis da cidade, de tudo isso é preciso vós tomardes conhecimento agora. $\mathrm{Na}$ verdade, juízes, peço-vos precisamente aquilo que eu penso ser conveniente requerer judicialmente, pois, sendo 
eu novo e também inexperiente no falar, penso ser conveniente mandar chamar Apolodoro como meu defensor para esse processo. (15) De fato, ele é mais velho do que eu, é mais experiente em leis, e ele mesmo está firmemente interessado em todas essas coisas e, ainda, foi injustiçado por este Estéfano aqui presente, de modo que ele seja o primeiro a vingar-se corretamente. Com essa verdade, é preciso que vós, depois de ouvirdes minuciosamente a acusação e a defesa, dessa forma, voteis já, em nome dos deuses, das leis, da justiça e também de vós mesmos.

\section{Defesa}

(16) Atenienses, eu subi à tribuna para acusar Neera, aqui presente, pelo fato de eu ter sofrido da parte de Estéfano todas aquelas coisas que Teomnesto acabou de vos dizer: que Neera é estrangeira, que está casada com Estéfano contrariamente às leis, tudo isso quero mostrar-vos claramente. Pois bem, em primeiro lugar, o escrivão lerá para vós a lei, segundo a qual Teomnesto intentou essa presente ação pública, e esse processo que se apresenta diante de vós.

\section{Lei}

Se por acaso um estrangeiro casar com uma cidadã, por qualquer que seja o artifício ou trama, aquele que desejar, entre os Atenienses, e para os quais isso é permitido, que intente uma ação pública perante os tesmótetas. Mas, se por acaso ele for condenado, que 
sejam vendidos ele mesmo e os seus bens, e um terço dos mesmos seja do acusador. Seja assim também, se uma estrangeira casar com um cidadão, também o marido da estrangeira, que tenha sido condenada, tenha uma multa de mil dracmas.

(17) Por conseguinte, juízes, vós acabastes de ouvir a lei que não permite que uma estrangeira case com um cidadáo ou a cidadá com um estrangeiro, nem que tenham filhos, por nenhum artifício ou nenhuma fraude; mas, se porventura alguém faz pouco caso disso, a lei estabelece que haja uma ação pública contra eles, contra o estrangeiro ou contra a estrangeira, diante dos testemotas; mas, se por acaso (um ou outro) for condenado, ordena a lei que seja vendido. Quero mostrar-vos, desde o início, minuciosamente, tudo isso: que esta Neera, aqui presente é, com certeza, estrangeira.

(18) De fato, Nicareta, que era liberta de Carísio de Élis e esposa de Hípias, aquele famoso cozinheiro, adquiriu essas sete mocinhas, desde pequenininhas; e ela era engenhosa e capaz de perceber a natureza especial das garotinhas, sabendo também criá-las e educá-las habilmente, já que era preparada nessa profissão e ganhava a vida com elas. (19) E depois de Nicareta tê-las chamado pelo nome de filhas, a fim de exigir as maiores somas possíveis daqueles que desejavam ter relaçóes sexuais com elas, na suposição de que fossem livres, e depois de ter desfrutado da juventude de cada uma delas, em síntese, vendeu os corpos de todas as sete: Anteia, Estrátola, Aristocleia, Metanira, Fila, Istmíada 
e Neera, aqui presente. ${ }^{8}$ (20) Qual delas, na verdade, cada um adquiriu e como foram libertadas dos que as compraram das mãos de Nicareta é o que eu vos mostrarei na sequência de meu discurso, se quiserdes ouvir e se eu tiver um resto de água na clepsidra. Que esta Neera, aqui presente, pertencia a Nicareta e traficava com o seu corpo, recebendo um salário daqueles que desejavam ter relaçóes com ela, isso quero recapitular mais uma vez para vós.

(21) $\mathrm{Na}$ verdade, Lísias, o sofista, ${ }^{9}$ por ser amante de Metanira, quis, além de outros gastos que despendia com ela, iniciá-la nos Mistérios, ${ }^{10}$ julgando que a própria dona se apoderava dos valores restantes. No entanto, aquilo que porventura gastasse com ela na festa e nos Mistérios viria a ser um agrado para a própria mulher. Portanto, ele pediu a Nicareta que fosse aos Mistérios com Metanira, a fim de que a jovem fosse iniciada, e ele mesmo ofereceu-se para isso. (22) Depois que elas chegaram, Lísias não as levou para a sua casa, envergonhado da esposa que tinha - filha de Braquilo e também sua sobrinha - e da sua mãe, que era bastante velha e também morava com ele. Como Filóstrato, do demo de Colono, era ainda solteiro e seu amigo, Lísias alojou-as, Metanira e também Nicareta, na casa dele.

${ }^{8}$ Este passo ajuda a confirmar a sua condição de escravas.

9 Era o conhecido Lísias, filho de Céfalo, meteco e logógrafo. A sua família era originária de Siracusa; Céfalo parece ter mudado para Atenas depois de ter sido persuadido por Péricles.

${ }^{10}$ Trata-se dos Mistérios de Elêusis, festividade que tinha lugar todos os anos, e onde podiam ser iniciados homens, mulheres, escravos e estrangeiros. 
Acompanhava-as também Neera, aqui presente, que já traficava com o corpo e era bastante nova, porque ainda não se encontrava na idade núbil. (23) Pois bem, como prova de que digo a verdade, que ela pertencia a Nicareta, que a acompanhava e que ela se prostituía com quem quisesse gastar dinheiro, como testemunha desses fatos vou chamar para vós o próprio Filóstrato.

\section{Testemunho}

Filóstrato, filho de Dionísio, do demo de Colono, testemunha saber que Neera pertencia a Nicareta justamente a quem Metanira também pertenceu -, que elas, quando vieram para os Mistérios, se alojaram na casa dele, e que moravam em Corinto. Testemunha, ainda, que Lísias, filho de Céfalo, que era seu amigo e era prestativo, estabeleceu-as em sua casa.

(24) Uma outra vez então, Atenienses, depois disso, Simo, o tessálio, chegou aqui com esta Neera para as grandes Panateneias. E Nicareta também a acompanhava; ficaram alojadas na casa de Ctesipo, filho de Glauconides, habitante do demo de Cidantidas, e Neera, aqui presente, bebia e comia na presença de muitos, como se fosse uma hetera. Como prova de que digo a verdade, vou chamar para vós as testemunhas desses fatos. (25) Chama-me Eufileto, filho de Simo, do demo Exone, e Aristómaco, filho de Critodemo, do demo de Alópece. 


\section{Testemunhas}

Eufileto, filho de Simo, do demo de Exone, Aristómaco, filho de Critodemo, do demo de Alópece, testemunham saber que Simo, o tessálio, chegou a Atenas para as Grandes Panateneias e que Nicareta e Neera, a acusada de hoje, estavam com ele; que eles as alojaram na casa de Ctesipo, filho de Glauconides, e que Neera frequentou os banquetes com eles, porque era uma hetera, e também com muitos outros que estavam presentes e se banqueteavam na casa de Ctesipo.

(26) Depois disso, então, quando ela trabalhava ostensivamente em Corinto e era célebre, Xenoclides, o poeta, e Hiparco, o ator, tornaram-se seus outros amantes. Eles mantinham-na como uma cortesã contratada. Como prova de que digo a verdade, não posso apresentar-vos o testemunho de Xenoclides, pois as leis não lhe permitem testemunhar. (27) Pois quando vós, persuadidos por Calístrato, salvastes os Lacedemónios, Xenoclides, naquele momento, tendose oposto na Assembleia do povo à expedição de socorro e tendo comprado, em tempo de paz, a quinquagésima parte do trigo da fazenda pública, e por ser necessário que ele fizesse os pagamentos ao Conselho a cada pritania e por não estar ele dispensado pelas leis de náo partir para aquela expedição, depois de ter sido acusado por este Estéfano aqui de deserçáo do serviço militar e ter sido difamado com esta acusação no tribunal, foi condenado e privado de seus direitos cívicos. (28) Portanto, como não podeis deixar de pensar que isso é terrível, se, por 
um lado, os cidadáos de nascimento, que participam legitimamente da cidade, este Estéfano aqui os privou do direito de falar e, por outro lado, forçou os que náo tinham nenhuma ligação connosco a ser Atenienses, contrariamente a todas as leis? Chamar-vos-ei o próprio Hiparco, obrigá-lo-ei a testemunhar ou a justificar-se sob juramento, conforme a lei, ou intimá-lo-ei. ${ }^{11}$ Chama-me Hiparco.

\section{Testemunho}

Hiparco, do demo de Atmonia, testemunha que Xenoclides e ele próprio, em Corinto, alugaram em seu proveito Neera, a acusada de hoje, porque ela era uma hetera das que se prostituíam, e que ela frequentava em Corinto os banquetes em companhia dele próprio e de Xenoclides, o poeta.

(29) Depois disso, então, dois outros tornaram-se seus amantes, o coríntio Timanóridas e o leucádio Êcrates, que pagaram o valor de trinta minas a Nicareta em troca do corpo da mesma, e compraram-na, segundo o direito local, para ser sua escrava, já que Nicareta era muito exigente com os encargos, determinando que eles assumissem diariamente por elas todas as despesas da casa. Possuíam-na e usavam-na por tanto tempo quanto desejavam. (30) Mas, estando prestes a casar, eles a advertiram de antemão que não queriam vê-la a trabalhar em Corinto nem submetida a um gerente de

${ }^{11}$ Uma situação próxima ocorre num discurso de Demóstenes sobre um processo comercial, Contra Zenótemis, D. 32.30. 
bordel, visto ter sido ela hetera de ambos; ao contrário, ser-lhes-ia mais agradável obter menos dinheiro da parte dela do que haviam pago, e também vê-la com uma boa situação. Então, disseram que, para a sua liberdade, lhe entregavam mil dracmas, quinhentos cada um, mas pediam-lhe que, procurando obtê-las com esforço, ela lhes restituísse as vinte minas. E ela, ao ouvir essas propostas de Êcrates e de Timanóridas, manda vir a Corinto outros de seus amantes, que a tinham possuído, e também Frínion, do demo de Peânia, que era filho de Démon e irmão de Demócares, que também passava a vida escandalosa e sumptuosamente, como lembram os mais velhos que vós. (31) Depois que Frínion chegou junto dela, ela lhe transmitiu as palavras que Êucrates e Timanóridas lhe disseram e entregou-lhe o dinheiro que recebera dos outros amantes, juntando a contribuição para a sua liberdade e, por conta disso, ela mesma forneceu algum dinheiro e pediu-lhe que, acrescentando ele o restante que faltava para as vinte minas, pagasse a Eucrates e a Timanóridas para que ela ficasse livre. (32) E ele, feliz por ter ouvido dela essas propostas e por ter recebido o dinheiro que ela trouxera para si mesma da parte dos outros amantes, e tendo ele próprio acrescentado o restante, pagou por ela as vinte minas a Eucrates e a Timanóridas, em troca de sua liberdade, com a condição de que ela não exercesse sua profissão em Corinto. Como prova de que digo a verdade, vou chamar para vós a testemunha ocular desses fatos. Chama-me Filagro, do demo de Mélite. 


\section{Testemunho}

Filagro, do demo de Mélite, testemunha que se encontrava em Corinto, no momento em que Frínion, irmão de Demócares, pagou vinte minas ao coríntio Timanóridas e ao leucádio Êucrates por Neera, a acusada de hoje, e que, depois de ter depositado o dinheiro, partiu para Atenas com Neera.

(33) Então, depois de ter chegado aqui com ela, ele a usava escandalosa e petulantemente e ia aos jantares, levando-a consigo por todos os lados onde ia beber, sempre frequentava os banquetes em sua companhia e, todas as vezes que queria, em toda a parte, estava com ela publicamente, dando aos que a olhavam a liberdade de um desejo. E não só foi com ela para um banquete na casa de muitos outros, mas também na casa de Cábrias de Exone, quando, sob o arcontado de Socratides, ${ }^{12}$ ele venceu os Jogos Píticos com a quadriga que comprara dos filhos do argivo Mítis, e, chegando de Delfos, celebrou a vitória em Colias. E aí mesmo, enquanto Frínion dormia, muitos outros tinham relaçôes com ela - que estava embriagada -, até mesmo os criados que punham a mesa de Cábrias. ${ }^{13}$ (34) Como prova de que digo a verdade, apresentar-vos-ei testemunhas que viram e estavam presentes. Chama-me, então, Quiónides, do demo de Xipete, e, Eutetíon, do demo de Cidateneu.

${ }^{12}$ Quer dizer em 374-73 a.C.

${ }^{13}$ Era um banquete que habitualmente se realizava para celebrar a vitória. 


\section{Testemunho}

Quiónides, do demo deXipete, Eutetíon, do demo de Cidateneu, testemunham que foram convidados por Cábrias para um banquete - no momento em que ele celebrava os festejos da vitória do carro de corridas -, que foram recebidos em Colias e testemunham saber que Frínion estava presente nesse banquete, em companhia de Neera, a acusada de hoje, e que eles próprios, Frínion e Neera, ali pernoitaram, e eles mesmos perceberam que outros e mais alguns dos criados, que eram servos de Cábrias, levantaram-se durante a noite para junto de Neera.

(35) Então, visto que era insultada de forma ultrajante por Frínion e não era amada como pensava, nem ele a servia em todas as coisas que ela desejava depois de ter recolhido todas as coisas da casa dele e tudo que tinha sido arranjado por ele para o seu corpo, vestidos e jóias, e mais duas servas, Trata e Cocaline -, foge para Mégara. Foi naquele tempo em que Asteios era arconte em Atenas, ocasião em que vós, durante a última disputa militar, fazíeis guerra aos Lacedemónios. ${ }^{14}$ (36) Ela permaneceu durante dois anos entre os Megarenses, $\mathrm{o}$ ano do arcontado de Asteios e o Alcístenes, ${ }^{15}$ porque o uso de seu corpo não the fornecia abundância suficiente para manter a casa (ela era esbanjadora, e

${ }^{14}$ Asteios foi arconte em 373-72 a.C. Em 374 a.C. tinha sido concluído um tratado de paz entre Atenas e Esparta, mas pouco tempo depois foi quebrado.

${ }^{15} \mathrm{O}$ arcontado de Alcístenes é datado de 372-71 a.C. 
os Megarenses, mesquinhos e avarentos, e também ali quase não havia permanência de estrangeiros, de um lado, porque havia guerra e os Megarenses eram do partido dos Lacedemónios e, de outro, porque tínheis o domínio do mar; e não lhe era permitido retornar a Corinto, porque, nesse lugar, fora libertada do jugo de Êucrates e Timanóridas, com a condição de não trabalhar naquela cidade). (37) Quando então chega a paz sob o arcontado de Frasiclides, ${ }^{16}$ e ocorre o combate entre Tebanos e Lacedemónios, em Leuctros, nesse momento, este Estéfano aqui veio para Mégara, alojou-se na casa dela, porque ela era uma hetera e teve relaçóes íntimas com ela, enquanto essa mulher, depois de lhe ter contado detalhadamente todos os fatos ocorridos e a insolência de Frínion e de lhe ter dado todas as coisas que tirara deste último, desejosa de manter residência ali mesmo, mas com medo de Frínion, por ter procedido mal com ele, e, ainda, com receio de que ele estivesse irritado com ela, porque sabia que o caráter dele era violento e negligente, toma este Estéfano aqui como seu protetor. (38) E ele, durante sua permanência em Mégara, tendo-a instruído com palavras e tendo-a enaltecido, de modo que Frínion se arrependeria se a tocasse - pois ele próprio a tomaria como esposa, introduziria, como se fossem seus, os filhinhos dela entre os membros da fratria, para torná-los cidadãos, e nenhum indivíduo os prejudicaria -, chega aqui, vindo de Mégara, com ela e mais três crianças pequenas, Próxeno, Aríston e uma filha, a quem hoje chamam Fano. (39) E ele a instala e

${ }^{16}$ Frasiclides foi arconte no ano de 371-70 a.C. 
também as criancinhas em uma pequena casa que lhe pertencia perto de Hermes Murmurante, ${ }^{17}$ entre a casa de Doroteu de Elêusis e a de Clinómaco, que Espíntaro comprara dele por sete minas. Depois de tê-la consigo, ele a trouxera por duas razóes: para ter gratuitamente uma bela hetera e para que não só ela arranjasse as coisas necessárias como também mantivesse a casa; de fato, não lhe restava outro caminho, exceto alguma coisa que ele recebia, procedendo como sicofanta. (40) Mas Frínion, tendo sabido que ela estava a morar na cidade e estava em casa daquele, tendo tomado consigo uns jovens e tendo ido a casa de Estéfano, pretendia levá-la. Estéfano, porém, libertando-a conforme a lei, tornou-se seu fiador diante o polemarca. Como prova de que digo a verdade, apresentar-vos-ei como testemunha desses fatos o polemarca daquela época. Chama-me Eetes de Ciríade.

\section{Testemunho}

Eetes de Ciríade testemunha que, quando ele próprio era polemarca, Neera, a acusada de hoje, foi obrigada por Frínion, irmão de Demócares, a pagar fiança e que se tornaram fiadores de Neera Estéfano, do demo de Eréadas, Gláucetes, do demo de Cefísia, e Aristócrates, do demo de Falero.

(41) Ora, tendo sido afiançada por Estéfano e estando na casa dele, continuava a exercer a mesma

${ }^{17}$ Pouco se sabe sobre este estranho epíteto de Hermes; vd. Kapparis (1999: 246). 
profissão não menos do que anteriormente; por outro lado, exigia as maiores quantias dos que queriam ter relaçóes com ela, porque, agora, ela estava com uma certa aparência e vivia com um homem. Mas ele também praticava chantagem de conivência com ela, caso apanhasse algum estrangeiro ingénuo e rico como amante dela, sequestrando-o como adúltero e exigindo-lhe uma grande quantia, como era natural. (42) $\mathrm{Na}$ verdade, nem Estéfano nem Neera tinham bens disponíveis, de modo que pudessem sustentar as despesas de cada dia - e a despesa da casa era constante, já que era preciso alimentar a ele, a ela, a três crianças pequenas que ela possuía e trouxera para a casa dele, duas servas e mais um empregado doméstico -, principalmente pelo fato de estar habituada a não passar mal, porque, anteriormente, outros lhe pagavam as coisas necessárias. (43) De fato, da política nada havia para Estéfano, aqui presente, que fosse digno de menção; na verdade, ele ainda não era um orador, mas apenas um sicofanta dos que lançam gritos perto da tribuna, que acusam mediante salário, que denunciam e, ainda, que se fazem de testa de ferro para as sentenças contrárias, até o momento em que ele ficou à disposição de Calístrato de Afidna. De que maneira e por que razão, é sobre isso que vos explicarei, quando eu demonstrar, acerca de Neera, aqui presente, que é estrangeira, que vos causou grandes prejuízos e ofendeu os deuses, (44) para que saibais que ele próprio é digno de receber uma punição não menor do que Neera, aqui presente, ao contrário, mais 
grave e um tanto maior, porque, afirmando ser um Ateniense, desprezou tanto mais as leis, vós mesmos e os deuses que, não se envergonhando de sua audácia de permanecer tranquilo acerca das faltas cometidas, mas acusando falsamente a outros e até a mim mesmo, suscitou contra ele mesmo e contra ela um processo tão grave, no qual foi examinado com cuidado quem ela é, e, por outro, foi comprovada a baixeza dele.

(45) Com efeito, tendo Frínion intentado contra Estéfano uma ação, porque ele lhe tinha roubado Neera, aqui presente, para conduzi-la à liberdade, e porque ele recebera todas as coisas que, trazendo consigo, ela própria tirara da casa dele, os amigos reuniram-nos e convenceram-nos a entregar-se à arbitragem deles. Se, por um lado, em favor de Frínion tomou assento como árbitro Sátiro, do demo de Alópece, irmão de Lacedemónio, por outro, em favor deste Estéfano aqui, tomou assento como árbitro Sáurias, do demo de Lamptras. De comum acordo, associaram-se a Diogíton, do demo de Acarnas. (46) E os árbitros, tendo-se reunido no santuário e ouvido de ambos e dessa própria mulher os fatos ocorridos, pronunciaram a sentença, e eles respeitaram-na: por um lado, que a mulher seja livre; por outro, que ela seja dona de si mesma, e que Neera, possuindo tudo que tirara da casa de Frínion - exceto vestidos, joias e criadas, que foram comprados para ela - devolva tudo a Frínion; e que viva com cada um dos dois em dias alternados. Mas, se eles, de algum outro modo, convencerem um ao outro, que isso seja confirmado; e aquele que a possui forneça 
sempre as coisas necessárias à mulher e que, durante o tempo restante, sejam amigos um do outro e não guardem rancor. (47) De fato, foi essa a conciliação pronunciada pelos árbitros para Frínion e Estéfano a respeito de Neera, aqui presente. Como prova de que digo a verdade, o escrivão fará para vós a leitura do testemunho desses fatos. Chama-me Sátiro, do demo de Alópece, Sáurias, do demo de Lamptras, e Diogíton, do demo de Acarnas.

\section{Testemunho}

Sátiro, do demo de Alópece, Sáurias do demo de Lamptras, e Diogíton, do demo de Acarnas, testemunham que, depois que se tornaram árbitros a respeito de Neera, a acusada de hoje, reconciliaram Estéfano e Frínion; a sentença de conciliação, pela qual eles se reconciliaram, é aquela que Apolodoro apresenta.

\section{Sentença de Conciliação}

De acordo com estas condiçóes, eles reconciliaram Frínion e Estéfano: cada um dos dois, tendo-a em sua própria casa os mesmos números de dias por mês, disponha de Neera, a não ser que aceitem alguma outra coisa para eles mesmos.

(48) Depois que se reconciliaram, os assistentes de cada um dos dois, durante a arbitragem e durante os acontecimentos - como, penso eu, é costume ocorrer 
em toda ocasiáo, sobretudo sendo o desacordo entre eles por causa de uma hetera - iam fazer a refeição na casa de cada um deles, sempre que possuíam Neera, e essa mulher aqui comia e bebia, porque era uma hetera. Como prova de que digo a verdade, chama-me como testemunha aqueles que se encontravam com eles, Eubulo, do demo de Probalinto, Diopites, do demo de Mélite, Ctéson, do demo do Cérames.

\section{Testemunho}

Eubulo, do demo de Probalinto, Diopites, do demo de Mélite, Ctéson, do demo de Cérames, testemunham que - depois que foi pronunciada a sentença de conciliação entre Frínion e Estéfano a respeito de Neera - muitas vezes jantaram com eles e beberam em companhia de Neera, a acusada de hoje, quando ela estava na casa de Estéfano, assim como quando na casa de Frínion.

(49) Assim, que ela era escrava desde as origens, que foi vendida duas vezes, que traficava com seu corpo, por ser uma hetera, que fugiu de Frínion para Mégara e que, ao chegar, foi obrigada a pagar fiança junto ao polemarca, porque era estrangeira, mostro-vos com o meu discurso, e tudo isso está atestado. Quero mostrar-vos, ainda, que o próprio Estéfano em pessoa prestou testemunho contra ela de que é estrangeira. (50) De fato, a filha desta Neera aqui, que ela trouxera quando a garotinha era pequena, e que, naquele tempo, chamavam Estribele, mas hoje Fano, Estéfano, aqui 
presente, deu-a em casamento, como se fosse sua própria filha, a um homem ateniense, Frastor, do demo de Egília, e ainda deu para ela um dote de trinta minas. Quando ela veio para a casa de Frastor, homem trabalhador e que juntou dinheiro com grandes dificuldades, não sabia satisfazer-lhe os hábitos, ao contrário, buscava os costumes de sua mãe e a desordem da casa dela, pois fora educada, penso eu, com tal liberdade. (51) Mas Frastor - vendo que ela não era honesta nem queria obedecer-lhe e, ao mesmo tempo, também já sabendo, de uma maneira segura, que ela não era filha de Estéfano, mas de Neera, e que fora enganado desde o início quando se casara na suposição de que tomava como esposa a filha de Estéfano e náo de Neera, ao contrário, na convicção de que era filha de uma mulher cidadã com ele, antes de viver com Neera -, ficando irritado com todas essas coisas e pensando não só ter sido ultrajado como também ter sido enganado, expulsa a mulher, que estava grávida, depois de estar casada com ela durante um ano, e náo devolve o dote.

(52) E depois de Estéfano ter intentado contra ele uma ação de alimento diante do Odéon - segundo a lei que determina, caso se repudie a mulher, que se devolva o dote, ou se não, que se paguem os juros a nove óbulos, e que seja possível ao tutor intentar, em favor da mulher, uma ação de alimento diante do Odéon,$-{ }^{18}$ Frastor propóe, diante dos tesmótetas, uma ação pública contra

${ }^{18}$ Também uma ação judicial por pensão alimentícia é motivo de referência no corpus dos Oradores Áticos, nomeadamente, por exemplo, em Iseu 3.9 e 78. 
Estéfano, aqui presente, por ter dado em casamento a ele, que é um Ateniense, a filha de uma estrangeira, como se ela fosse sua própria parente, conforme a presente lei. Lê para mim a lei.

\section{Lei}

Se alguém der em casamento a um cidadão ateniense uma mulher estrangeira, como se ela fosse sua própria parenta, que seja privado dos direitos cívicos e que a sua fortuna seja do Estado e a terça parte do acusador. Proponham uma ação pública, diante dos tesmótetas, aqueles a quem isso é permitido, assim como uma ação por usurpação do direito de cidadania.

(53) O escrivão leu então para vós a lei, segundo a qual este Estéfano aqui foi acusado por Frastor diante dos tesmótetas. E Estéfano, tendo ficado ciente de que correria perigo - se fosse reconhecido culpado por ter dado em casamento a filha de uma estrangeira - de que incorreria nas penas mais graves, reconciliouse com Frastor, renunciou ao dote e retirou a ação de alimento, enquanto Frastor retirou sua acusação dos tesmótetas. Como prova de que digo a verdade, chamar-vos-ei como testemunha desses fatos o próprio Frastor e obrigá-lo-ei a testemunhar, conforme a lei. (54) Chama-me Frastor, do demo de Egília. 


\section{Testemunho}

Frastor, do demo de Egília, testemunha que, depois que percebeu que Estéfano lhe dera em casamento a filha de Neera, como se ela fosse sua própria filha, intentou contra ele uma ação pública diante dos tesmótetas, conforme a lei, expulsou a mulher de sua própria casa, não mais viveu com ela e que - depois de Estéfano ter proposto contra ele uma ação de alimento, diante do Odéon - Estéfano se reconciliou com ele, de modo que foi retirada dos tesmótetas a ação pública, assim como a ação de alimento, que Estéfano intentara contra mim.

(55) Pois bem, desejo ainda oferecer-vos um outro testemunho não só de Frastor, mas também dos membros de sua fratria e dos membros de seu genos, como prova de que esta Neera aqui é estrangeira. De fato, não muito tempo depois que Frastor repudiara a filha de Neera, ele ficou doente, esteve muito mal e viu-se numa situação completamente sem saída. E porque havia uma antiga diferença, ressentimento e ódio entre ele e seus familiares e, além disso, porque não tinha filhos, fora consolado na doença pelos cuidados de Neera e de sua filha (de fato, elas iam para junto dele, (56) quando estava doente e sem ninguém que cuidasse de sua enfermidade, levando as coisas necessárias à sua doença e visitando-o; e vós mesmo sabeis, sem dúvida, o quanto uma mulher é preciosa nas enfermidades, assistindo um homem doente). Além disso, a criança que a filha de Neera, aqui presente, concebera - quando, 
estando grávida, foi repudiada por Frastor porque ele soube que ela não era filha de Estéfano, mas de Neera e porque se irritou com essa traição - ele foi persuadido a tomá-la novamente e a adotá-la como seu próprio filho. (57) Fazendo um raciocínio humano e natural, já que estava mal e não havia muita esperança de ele sobreviver e para que os seus parentes náo recebessem os seus bens nem ele morresse sem filhos, adotou a criança e acolheu-a em sua casa; agora, demonstrar-vos-ei, com uma prova importante e clara, que ele, se estivesse sadio, jamais agiria assim. (58) De fato, logo que Frastor saiu daquela enfermidade, restabeleceu-se e seu corpo ficou saudável, tomou como esposa, conforme as leis, uma cidadã, filha legítima de Sátiro, do demo de Mélite, e irmã de Dífilo. Assim, recebera a criança, não por vontade própria, mas por ter sido pressionado pela doença, pela falta de filhos, pelo cuidado delas e, ainda, pela inimizade com os seus familiares, a fim de que eles não se tornassem herdeiros de seus bens, caso algum mal lhe acontecesse. Que todos esses fatos sejam provas para vós. Aliás, a sequência deles demonstrá-lo-á ainda mais. (59) Na verdade, porque estava doente, Frastor pretendia introduzir entre os membros de sua fratria aquela criança, a da filha de Neera, e também entre os Brítidas, dos quais o próprio Frastor também é membro. Sem dúvida, os membros do genos, ao saberem, penso eu, quem era aquela mulher que Frastor tomara inicialmente - a filha de Neera - , sabedores do repúdio da mulher e de que ele consentira em receber a criança novamente por causa 
da doença, excluíram a criança e não a inscreveram entre eles. (60) Depois que Frastor intentou contra eles um processo por não terem inscrito seu filho, os membros do genos intimaram-no diante do árbitro a jurar por vítimas imaculadas, depois de considerar que o filho dele nascera de uma mulher cidadã e esposa legítima, conforme a lei. E quando os membros do genos intimaram Frastor diante do árbitro sobre essas coisas, ele faltou e não prestou o juramento. ${ }^{19}$ (61) Como prova de que digo a verdade, desses fatos apresentar-vos-ei testemunhas presentes da parte dos Brítidas.

\section{Testemunhas}

Timóstrato, do demo de Hécale, Xantipo, do demo de Eréadas, Evalces, do demo de Falero, Ânito, do demo de Lacíadas, Eufranor, do demo de Egília, Nicipo, do demo de Céfalas, testemunham que eles mesmos, assim como Frastor, do demo de Egília, pertencem ao genos chamado Brítidas e, que, quando Frastor reclamou o direito de introduzir seu filho entre os membros do genos, estes, sabedores de que o filho de Frastor era da filha de Neera, impediram-no de introduzir o filho nesse genos.

(62) Mostro-vos, então, claramente que também estes, os mais íntimos de Neera, aqui presente,

${ }^{19} \mathrm{O}$ ato do pai prestar um juramento legal aos membros do genos (os gennetai) era sinal que o seu filho tinha nascido cidadão de uma cidadã, dada em casamento legítimo, e que tal ato havia sido testemunhado. Há diversos exemplos no corpus demosthenicum de momentos como este mencionado por Apolodoro, por exemplo, Contra Beóto 1.4; 2.11; Contra Calipo 15, Contra Eubúlides 23-40 e 54. 
testemunharam que ela é estrangeira: Estéfano, que a tem atualmente por mulher e que vive com ela, e Frastor, que tomou como esposa a filha dela; mostro-vos que Estéfano, então, não querendo sustentar um processo em favor da filha dela, foi acusado por Frastor, diante dos tesmótetas, porque dera em casamento a filha de uma estrangeira a este último, que era um Ateniense, e que ele, Estéfano, renunciou ao dote e não o recuperou. (63) Mostro-vos que Frastor, depois de estar casado, expulsou a filha de Neera, aqui presente, logo que soube não ser ela filha de Estéfano, e não devolveu o dote; e quando foi persuadido, em seguida, por causa de sua doença, da falta de filhos e da inimizade com seus familiares, a reconhecer o filho e, ainda, quando tentava introduzi-lo entre os membros do genos, ele náo quis jurar - por terem os membros do genos rejeitado o filho e por lhe concederem o direito de um juramento -, mas preferiu evitar um perjúrio; e mostrar-vos que depois ele casou com uma outra mulher, uma cidadá, conforme a lei. $\mathrm{Na}$ verdade, esses fatos, que são evidentes, forneceram contra eles importantes testemunhos de que Neera, aqui presente, é estrangeira.

(64) Examinai atentamente, portanto, a avidez de Estéfano, aqui presente, e a sua baixeza, a fim de que saibais também, com base nessa constatação, que Neera, aqui presente, não é uma cidadã. De fato, sendo Epéneto de Andros um antigo amante de Neera, tendo gastado muito com ela e alojando-se na casa deles sempre que vinha a Atenas, por causa de sua amizade por Neera, (65) este Estéfano aqui, tendo-lhe preparado 
uma armadilha e tendo-o mandado para o campo, sob o pretexto de oferecer um sacrifício aos deuses, apanhou-o em flagrante delito de adultério com a filha de Neera, aqui presente. ${ }^{20}$ Tendo-o detido por coação, exigiu-lhe trinta minas e, tendo tomado como fiadores de ambos Aristómaco que tinha sido tesmóteta, e Nausífilo, filho de Nausinico, que tinha sido arconte, ele o soltou, para que Epéneto lhe pagasse o dinheiro.

(66) Mas Epéneto, depois de ter saído dali e de ter-se tornado livre, move, diante dos tesmótetas, uma ação pública contra Estéfano, aqui presente, porque foi sequestrado ilicitamente por ele, segundo a lei que determina, caso alguém sequestre ilegalmente a outrem como adúltero, propor uma açáo pública diante dos tesmótetas, por ter sido sequestrado de maneira ilícita, e caso se condene o sequestrador ou se julgue ter este preparado, em seu próprio interesse, uma armadilha ilicitamente, a lei determina ser a vítima dispensada de resgate e serem os fiadores dispensados de fiança. Por outro lado, caso se julgue ser ele um adúltero, a lei determina que os fiadores o entreguem ao que teve ganho de causa e, no tribunal, exceto com arma cortante, fazer do condenado aquilo que quiser, na convicção de que ele é um adúltero. (67) Então, de acordo com essa lei, Epéneto intentou contra ele uma ação pública na qual reconhecia ter tido relaçóes com aquela criatura. Entretanto, declarava não ser um adúltero; na verdade, ela nem mesmo era filha de Estéfano, mas de Neera, e a

${ }^{20} \mathrm{O}$ discurso de Lísias 1, Acerca do Assassínio de Eratóstenes, oferece informaçóes importantes sobre o adúltero surpreendido em flagrante delito. 
mãe dela estava ciente de que a filha mantinha relaçóes sexuais com ele. Além disso, ele tinha gastado muito com elas as duas e sustentava a casa toda, sempre que vinha cá. Apresentando a respeito desses fatos a lei que não permite fazer a constatação de adultério em relação àquelas todas que habitam em um prostíbulo ou se prostituem abertamente, afirmava repetidamente que a casa de Estéfano era um prostíbulo, que o meio de vida dela era esse e que eles prosperavam muitíssimo com a prostituição. (68) Depois que Epéneto expôs essas razóes e registrou a ação pública, Estéfano, aqui presente, tendo percebido que seria condenado por manter uma casa de prostituição e por agir de má-fé, submeteu-se, diante de Epéneto, à arbitragem dos próprios fiadores, de modo que eles fossem dispensados da fiança e Epéneto retirasse a ação pública. (69) Mas, tendo Epéneto sido convencido acerca dessas coisas e retirado a ação que intentara contra Estéfano, depois de ter ocorrido uma sessão de acareação entre eles e os fiadores tomarem assento como árbitros, Estéfano nada podia dizer de justo, mas pedia a Epéneto que contribuísse para o estabelecimento da filha de Neera, alegando a sua falta de recursos e a desgraça que acontecera anteriormente à mulher junto a Frastor e, ainda, que ele perdera o dote e não poderia dá-la em casamento novamente. (70) "Quanto a ti, tu também te aproveitaste dessa mulher dizia ele - e é justo que faças alguma coisa de bom para ela", e disse também outras palavras persuasivas que alguém poderia dizer para livrar-se de circunstâncias difíceis. Os árbitros, então, depois de ouvir a ambos, 
reconciliaram-nos e convenceram Epéneto a contribuir com mil dracmas para o dote da filha de Neera. Como prova de que digo a verdade, vou chamar para vós como testemunhas desses fatos os próprios fiadores, que também foram árbitros.

\section{Testemunhas}

(71) Nausífilo e Aristómaco, ambos do demo de Céfalas, testemunham que se tornaram fiadores de Epéneto de Andros, quando Estéfano disse tê-lo apanhado em flagrante delito de adultério. E depois que Epéneto se desvencilhou de Estéfano e tornou-se livre, testemunham que ele propôs uma ação pública contra Estéfano, diante dos tesmótetas, porque este o sequestrara ilicitamente, e testemunham que eles mesmos, tendo-se tornado árbitros, conciliaram Epéneto e Estéfano e que a reconciliação é esta que Apolodoro apresenta.

\section{Reconciliaçáo}

Os árbitros reconciliaram Estéfano e Epéneto nessas condiçôes: que não haja nenhuma lembrança dos acontecimentos passados a respeito da detenção, que Epéneto dê mil dracmas a Fano para o seu dote, uma vez que teve relaçóes com ela muitas vezes. Por outro lado, que Estéfano coloque Fano à disposição de Epéneto, todas as vezes que ele vier hospedar-se na cidade e desejar estar com ela. 
(72) Portanto, a mulher está publicamente reconhecida como uma estrangeira, ela por quem este indivíduo ousou fazer uma verificação de adultério. E este Estéfano e esta Neera, aqui presentes, chegaram a tal ponto de insolência e de impudência que tiveram a ousadia de não se conformar em afirmar ser ela uma cidadâ, mas, tendo eles observado que Teógenes, do demo de Corónides - homem nobre por nascimento, porém pobre e inexperiente em relação aos negócios públicos -, fora sorteado como arconte-rei, Estéfano, aqui presente, tendo-o assistido quando passara pelo exame de docimasia, e tendo-o ajudado com seus próprios recursos nas despesas, quando Teógenes foi empossado no cargo, tendo-se insinuado e comprado da parte dele o cargo e tendo-se convertido em seu paredro, ${ }^{21}$ deulhe esta mulher, a filha de Neera, como esposa, e mais, este Estéfano aqui casou-a como se ela fosse sua própria filha. Assim, este homem muito desprezou as leis e a vós. (73) Essa mulher, então, celebrou para vós os sacrifícios secretos em nome da cidade, viu também as coisas que não convinha que ela visse, sendo estrangeira, e, sendo ela quem é, entrou onde nenhum outro entre os

${ }^{21} \mathrm{O}$ arconte epónimo, o arconte basileus e o polemarco escolhiam para si próprios dois paredroi ou assessores para os auxiliarem, como refere Arist. Ath. 56.1. Não havia restrição sobre a escolha do basileus do paredro. Teógenes estava autorizado a designar o seu sogro se ele quisesse. A alegaçáo de Apolodoro que Estéfano pagou a Teógenes para o nomear está preparada para denegrir a imagem de Estéfano, porque é importante notar que Apolodoro não fornece nenhuma prova de que o cargo foi realmente comprado; casos semelhantes são testemunhados noutros discursos áticos, e.g. [D.] 58.32, D. 21.179 . 
Atenienses, que são tão numerosos, logrou entrar, exceto a mulher do arconte-rei; recebeu também o juramento das sacerdotisas que a assistem nos sacrifícios, foi dada como esposa a Dioniso, cumpriu em nome da cidade os ritos dos ancestrais, junto aos deuses, ritos numerosos, sagrados e misteriosos. E tudo aquilo que não é permitido a todos ouvir, como é que, à primeira mulher que chega, é possível agir piedosamente, principalmente a uma mulher desse tipo, que exerceu tais atividades de prostituição?

(74) Quero, com a maior exatidáo, expor-vos em pormenor acerca desses assuntos, desde o início, a fim de tomardes mais cuidado com a punição e saberdes que votareis não somente em favor de vós mesmos e das leis, mas também em função do dever de piedade para com os deuses, vingando-vos das impiedades e punindo os culpados. ${ }^{22} \mathrm{Na}$ verdade, Atenienses, no início havia na cidade uma oligarquia, a realeza pertencia sucessivamente aos que dominavam, por serem eles nativos da regiáo, e o rei oferecia todos os sacrifícios, e sua esposa, sendo a rainha, celebrava, convenientemente, os mais veneráveis e misteriosos sacrifícios. $^{23}$ (75) Depois que Teseu os unificou, criou a democracia e a cidade tornou-se muito populosa, o povo, erguendo as mãos, elegia nada menos que um

${ }^{22}$ Cf. Contra Neera 77.

${ }^{23}$ A cerimónia principal em que a mulher do basileus participava era a do casamento com Dioniso, que acontecia no segundo dia das Antestérias (Fevereiro-Março), como é referido em Contra Neera 76. As cerimónias preliminares pareciam ser realizadas no templo de Dioniso, em Limnas. O casamento tinha lugar no Bucólio; cf. Arist. Ath. 3.5. 
rei entre os preferidos, de acordo com sua dignidade, mas para sua esposa estabeleceram uma lei: ser ela cidadã e não se ter imiscuído com outro homem, mas casar-se virgem, para que os sacrifícios secretos fossem celebrados em nome da cidade, conforme os costumes dos antepassados, e as coisas consagradas pelo uso fossem realizadas piedosamente para os deuses, e nada fosse revogado nem inovado. (76) E tendo eles gravado essa lei numa estela de pedra, ergueram-na no santuário de Dioniso, perto do altar, em Limnas (e essa estela ainda hoje está de pé, mostrando as escrituras em caracteres áticos, sem nitidez ${ }^{24}$ ), dando o povo um testemunho de sua própria piedade para com o deus e deixando um marco depositado aos pósteros, porque exigimos que a mulher seja de tal tipo, para ser dada em casamento ao deus e cumprir os rituais. Por causa disso, então, ergueram a estela no mais antigo santuário de Dioniso e no mais santo, em Limnas, para que poucos conheçam as escrituras; de fato, ele só é aberto uma vez cada ano, no décimo segundo dia do mês Antestérion. (77) Ora, a respeito de ritos augustos e veneráveis, com os quais os vossos ancestrais se ocuparam táo bela e magnificamente, é conveniente também vós serdes zelosos, Atenienses, e é conveniente castigardes, por um lado, os que desprezaram imprudentemente as vossas leis e, por outro, os que cometeram, sem pudor, um sacrilégio para com os deuses, por dois motivos: para que eles sejam punidos por suas faltas e para que os demais tomem cuidado antecipadamente e sintam

\footnotetext{
${ }^{24}$ Anteriores ao ano de 403 a.C.
} 
medo de cometer uma falta, não só com respeito aos deuses, mas também com respeito à cidade.

(78) Então, quero chamar para vós o arauto sagrado - que assiste a esposa do rei quando, perto do altar, ela faz as sacerdotisas jurarem sobre as cestas, ${ }^{25}$ antes de tocarem nos bens sagrados - para ouvirdes o juramento e as palavras ditas, tanto quanto é permitido ouvir, e para saberdes como esses ritos são veneráveis, sagrados e antigos.

\section{Juramento das sacerdotisas}

Estou em estado de graça, imaculada e isenta das demais coisas que não são puras e, ainda, de união física com homem. Então, celebrarei as Theoinia e as Iobaccheia em honra de Dioniso, conforme os costumes dos ancestrais e nas épocas determinadas.

(79) Pois bem, acabastes então de ouvir o juramento e os costumes dos ancestrais consagrados pelo uso - tal como é permitido proferir - e de que modo essa mulher, que Estéfano deu em casamento a Teógenes, enquanto era rei, como se fosse sua própria filha, realizava esses sacrifícios e recebia o juramento das sacerdotisas; acabastes de ouvir que não é permitido a elas mesmas, que assistem a esses sacrifícios, falar a ninguém sobre eles. Vamos, então, quero apresentar-vos um testemunho que permaneceu em segredo, e, não obstante, por meio desses próprios fatos, mostrarei que ele

${ }^{25}$ Eram catorze as mulheres que assistiam a mulher do arconte rei nas suas funçóes religiosas. 
é claro e verdadeiro. (80) De fato, logo que se realizaram esses sacrifícios e os nove arcontes, nos dias marcados, subiram ao Areópago, imediatamente o Conselho do Areópago - visto que ele é muito importante para a cidade com relação à devoção e a tudo mais - procurou saber quem era essa esposa de Teógenes e provou a verdade. Além do mais, o Conselho se ocupava dos sacrifícios em relação aos quais ele é autoridade e puniu Teógenes em segredo e também por conveniência: na verdade, os membros do Conselho náo são livres para castigar qualquer um dos Atenienses como quiser. (81) Tendo ocorrido discussóes e o Conselho do Areópago estando descontente e condenando Teógenes, porque ele tomara essa tal mulher como esposa e permitira que ela realizasse esses sacrifícios secretos em nome da cidade, Teógenes recorreu, suplicando e implorando aos juízes, dizendo que não sabia que ela era filha de Neera, mas que fora enganado por Estéfano, tomando-a como se ela fosse filha legítima deste, conforme a lei; e por causa de sua inexperiência nos negócios públicos e de sua inocência, nomeou-o seu assessor, para ajudá-lo no governo, na suposição de que ele fosse um amigo, e por isso tornou-se seu parente. (82) "Demonstrar-vos-ei, dizia ele, por meio de uma prova importante e clara, que não minto: expulsarei a mulher de minha casa, já que ela não é filha de Estéfano, mas de Neera. Caso eu faça isso, que as palavras pronunciadas por mim sejam, a partir de agora, dignas de fé para vós, porque fui enganado; caso eu não o faça, então castigai-me agora, como se eu fosse perverso e ímpio para com os deuses." (83) Depois 
de Teógenes ter prometido essas coisas e de suplicar, o Conselho de Areópago, em parte tendo-se apiedado dele por causa da inocência de sua atitude, em parte pensando ter sido ele realmente enganado por Estéfano, converteu o julgamento em diligência. Assim que Teógenes desceu do Areópago, imediatamente expulsou a mulher de casa, a filha de Neera, aqui presente, e excluiu do colégio de magistrados este Estéfano aqui, que o enganara. E assim os membros do Areópago deixaram de perseguir Teógenes e de irritar-se com ele e concederam-lhe o perdão por ter sido enganado. (84) Como prova de que digo a verdade, chamarei para vós como testemunha desses fatos o próprio Teógenes e vou obrigá-lo a testemunhar. Chama-me Teógenes, do demo de Érquia.

\section{Testemunho}

Teógenes, do demo de Érquia, testemunha que, quando ele era rei, casou-se com Fano, como se ela fosse filha de Estéfano, mas, quando percebeu que fora enganado, expulsou a mulher e náo mais viveu com ela; além disso, afastou Estéfano de suas funções de paredro e não mais permitiu que fosse seu assessor.

(85) Traze-me, pois, precisamente esta lei, além daquelas, e lê, para saberdes que era conveniente que a mulher, sendo de tal espécie e realizando coisas desse género, se abstivesse não só desses sacrifícios, de assistir a eles, de celebrare de praticar, em nomeda cidade, qualquer um dos costumes dos ancestrais consagrados pelo uso, 
mas também se abstivesse de todos os outros sacrifícios em Atenas. Na verdade, em relação a uma mulher que seja apanhada em flagrante delito de adultério, não lhe é permitido ir a nenhum dos sacrifícios públicos, para os quais as leis deram à estrangeira e à escrava a liberdade de ir e de entrar, para assistir ou para suplicar. (86) Mas, quanto àquelas que sejam apanhadas em flagrante delito de adultério, somente a essas mulheres as leis proíbem entrar nos santuários públicos; mas caso entrem e violem as leis, sofram aquilo que se deve sofrer, exceto a morte, da parte de quem desejar castigá-las, sem punibilidade para este; em tais casos, a lei dá ao primeiro que chega o direito de praticar sevícias e, por causa disso, instituiu outros castigos, com exceçáo da morte - e que a mulher que sofreu maus-tratos nunca obtenha reparação, a fim de que não surjam manchas nem impiedades nas coisas sagradas. Esta lei causa nas mulheres um temor capaz de torná-las moderadas e de não cometerem erros, mas guardarem a casa honestamente. Instrui a lei que, se ela cometer algum erro de tal natureza, será, ao mesmo tempo, excluída da casa do marido e dos cultos da cidade. $^{26}$ (87) Como prova de que é assim, sabereis, ao ouvir a própria lei depois de lida. Então, traze-me a lei.

\section{Lei de adultério}

Todas as vezes que se apanha em flagrante o adúltero, não seja permitido ao que flagrou conviver

${ }^{26}$ A lei revelava-se severa para as mulheres que tivessem tido um comportamento adúltero, tal como Ésquines refere em Contra Timarco, 183. Esta lei é atribuída a Sólon. 
com a mulher; caso, porém, conviva, seja privado da cidadania. E também à mulher, em relação à qual haja flagrante de adultério, não lhe seja permitido entrar nos santuários públicos; mas, caso ela entre, sofra aquilo que se deve sofrer, exceto a morte, sem punibilidade para quem a castigar.

(88) Pois bem, quero trazer-vos, Atenienses, um testemunho do povo de que ele se ocupa ativamente desses cultos e de que toma muito cuidado com esses assuntos. De fato, o povo ateniense, sendo o mais soberano em tudo na cidade-estado e sendo-lhe permitido fazer aquilo que deseja, considerou que o fato de se tornar Ateniense é um privilégio táo honroso e respeitável que estabeleceu leis para si mesmo, segundo as quais se deve fazer alguém cidadão, caso eles queiram - leis que foram agora ultrajadas por este Estéfano aqui e por aqueles que contraíram casamento dessa maneira. (89) Depois de ouvires os fatos, tornar-vos-ei mais dignos e ficareis cientes de que elas violaram as mais belas e as mais nobres dádivas concedidas aos que prestam um serviço à cidade. De fato, há, em primeiro lugar, uma lei estabelecida para o povo de náo permitir fazer cidadáo ateniense aquele que não seja digno, por sua hombridade para com o povo ateniense, de se tornar um cidadão. Em seguida, depois que o povo consente e concede este privilégio, não permite que a concessão do direito de cidadania seja confirmada se, pelo voto, na Assembleia seguinte, mais de seis mil votantes entre os atenienses náo votarem secretamente. (90) Mas a lei ordena aos prítanes colocar as urnas e entregar o voto ao 
povo quando chega, antes que os estrangeiros entrem e aqueles retirem as barreiras, a fim de que cada um em particular, com independência, reflita consigo mesmo sobre quem esteja na iminência de tornar-se cidadão, se é digno desse privilégio aquele que está prestes a recebêlo. Em seguida, depois desses procedimentos, a lei criou para quem quiser, entre os Atenienses, uma acusação de ilegalidade contra o candidato, e é possível a quem quiser comparecer perante o tribunal para provar que o candidato náo é digno desse privilégio, mas que se tornou um cidadáo contrariamente às leis. (91) E depois de o povo já ter concedido esse privilégio a alguém e ter sido enganado pelos solicitantes com um discurso, uma acusação de ilegalidade ter ocorrido e ter sido proposta junto ao tribunal, foi provado que aquele que recebera esse privilégio não era digno dele, e o tribunal o retirou. E não só muitas pessoas mas também os antigos contam um fato: o tribunal retirou esses privilégios tanto do tessálio Pítolas quanto do olíntio Apolónides, que se tornaram cidadãos graças ao povo, coisas de que todos vós lembrais. (92) $\mathrm{Na}$ verdade, esses acontecimentos não são antigos para que vós os ignoreis. Com efeito, depois que foram estabelecidas leis a respeito do direito de cidadania, de modo táo conveniente e rigoroso, por meio das quais se deve vir a ser Ateniense, além de todas essas, estabeleceu-se uma outra lei totalmente em vigor; assim, o povo tomava muito cuidado para a defesa de si mesmo e dos deuses, para que os sacrifícios fossem cumpridos piedosamente em nome da cidade. De fato, a quantos o povo ateniense torne cidadáos, a lei proíbe 
terminantemente que lhes seja permitido tornarem-se um dos nove arcontes ou de participarem de qualquer sacerdócio. O povo já lhes deu uma parte de todos esses direitos a partir de seus descendentes e acrescentou: "se eles forem nascidos de uma mulher cidadã e regularmente dada em casamento, conforme a lei.” (93) Como prova de que digo a verdade, demonstrar-vos-ei isso com um testemunho importante e evidente. Ora, quero expor-vos primeiramente esta lei, vigente há muito, de que maneira ela foi instituída e para quem foi prescrita: para indivíduos que são honestos e se tornaram fiéis amigos do povo. $\mathrm{Na}$ verdade, depois desses acontecimentos, sabereis que esse privilégio do povo, reservado aos seus benfeitores, foi ultrajado, e de quantas coisas boas este Estéfano aqui e os homens que estão casados e que têm filhos da mesma maneira que ele impediram-vos de ter esse direito.

(94) De fato, Atenienses, os Plateenses, únicos entre os Gregos, vieram em vosso socorro em Maratona, quando Dátis, general do rei Dario, retirando-se de Erétria, depois de ter submetido Eubeia, desembarcou em nosso território com uma grande força militar e a devastou. E ainda hoje mesmo uma pintura no pórtico colorido mostra um monumento da coragem deles: na verdade, ficou registrado que cada um, os que possuem os capacetes beócios, vindo imediatamente prestar socorro, tomava a velocidade que podia. (95) Uma segunda vez, quando Xerxes veio para a Grécia, sendo os Tebanos do partido dos Medos, os Plateenses não tiveram a coragem de abandonar a vossa aliança, mas 
somente a metade dos Beócios, tendo-se colocado em ordem de batalha com os Lacedemónios e com Leônidas nas Termópilas, pereceu em confronto com o atacante bárbaro, enquanto os restantes, tendo embarcado em vossas trirremes, porque não havia à disposição deles um barco próprio, combateram convosco perto do Artemísio e em Salamina. (96) E durante a última luta contra Mardónio, general do Grande Rei, em Plateias, eles, tendo combatido convosco e com os que ajudaram a libertar a Grécia, conferiram para o bem comum a liberdade aos outros Gregos. E quando Pausânias, rei dos Lacedemónios, pretendia humilharvos e não estava satisfeito com o fato de que somente os Lacedemónios fossem considerados os dignos de comando pelos Gregos, e com o fato de que Atenas, que efetivamente comandava a liberdade dos Gregos, por ambição, não se opusesse aos Lacedemónios, a fim de que estes não fossem invejados pelos aliados, (97) razóes pelas quais Pausânias, rei dos Lacedemónios, tendo-se enchido de orgulho, inscreveu no tripé de Delfos, aquele que os Gregos, que ajudaram no combate de Plateias e combateram na batalha naval de Salamina, tendo tomado dos Bárbaros, consagraram a Apolo em comum como prémio da sua bravura:

Chefe militar dos Gregos, Pausânias, depois que destruiu o exército dos Medos, consagrou este monumento a Febo, ${ }^{27}$ como se a vitória e a oferenda fossem somente dele e não em conjunto com os aliados.

${ }^{27}$ A narrativa deste acontecimento em Tucídides (I. 132.2-3) refere apenas que os Espartanos retiraram a inscrição de Pausânias da trípode de imediato e substituíram-na com os nomes dos estados gregos. 
(98) E pelo fato de os Gregos ficarem irritados, os Plateenses instauraram, em nome dos aliados, contra os Lacedemónios, um processo de mil talentos, diante do Anfictiáo, e, obrigaram-nos a apagar o dístico e a inscrever as cidades que tinham participado do combate. Principalmente por causa disso, perseguiaos o ódio dos Lacedemónios e da família do Rei. E nessa circunstância, os Lacedemónios não sabiam o que fazer com eles, porém, uns cinquenta anos mais tarde, Arquidamo, rei dos Lacedemónios e filho de Zeuxidamo, em tempo de paz, tentou apoderar-se da cidade de Plateias. (99) E Arquidamo fizera essas coisas por intermédio do beotarco de Tebas, Eurímaco, filho de Leoncíades, porque Nauclides e alguns outros, juntamente com Eurímaco, deixando-se persuadir por dinheiro, abriram-lhe as portas durante a noite. Mas os Plateenses, tendo percebido que os Tebanos estavam de noite no interior e que a sua cidade fora tomada de surpresa em tempo de paz, vieram socorrê-la, e eles próprios puseram-se em ordem de batalha. Depois que amanheceu e eles viram que os Tebanos não eram numerosos, mas que os primeiros deles tinham entrado em Tebas (pois a chuva, tendo caído forte durante a noite, impediu que todos eles entrassem; de fato, o rio Asopo corria forte e não era fácil atravessá-lo, principalmente à noite), (100) então, como os Plateenses viram os Tebanos em sua cidade e perceberam que nem todos estavam presentes, atacaram-nos e, depois de travarem combate, venceram-nos e apressaram-se para matá-los, antes que os outros viessem em socorro; em seguida, 
enviaram para vós um mensageiro para anunciar o ocorrido e para mostrar que tinham vencido a batalha, e mais, pedindo que os socorressem, caso os Tebanos destruíssem o território deles. Mas os Atenienses, tendo tomado conhecimento dessas ocorrências, vieram rapidamente em socorro de Plateias; e como os Tebanos viam que os Atenienses tinham vindo em socorro dos Plateenses, voltaram para a sua pátria. ${ }^{28}$ (101) Então, como os Tebanos fracassaram com essa tentativa e os Plateenses mataram os prisioneiros que eles apanharam vivos durante a luta com eles, os Lacedemónios, irritados, marcharam imediatamente, sem motivos para isso, contra Plateias, tendo ordenado não só a todos os habitantes do Peloponeso, exceto os Argivos, que mandassem de cada uma das cidades dois terços de seu exército, e, ainda, tendo ordenado a todos os outros Beócios, Locrenses, Focenses, Malianos, Eteus e Enianes que avançassem em massa. (102) E bloqueando a muralha dos Plateenses com uma tropa numerosa, os Lacedemónios enviaram-lhes uma ordem: se quisessem entregar-lhes a cidade, mas manter o território e ter a posse de seus próprios bens, que renunciassem a aliança com os Atenienses. Mas os Plateenses, não tendo consentido e tendo respondido que nada fariam sem os Atenienses, assediaram-nos por dois anos, tendoos cercado com um muro duplo, depois de realizarem muitas e variadas tentativas. (103) Mas quando os Plateenses perderam a resistência e ficaram carentes de tudo e, ainda, duvidavam de sua salvação, tendo tirado

${ }^{28}$ Cf. Tuc. II. 2-6, 71sqq., III. 20-24 e 52-68. 
à sorte entre eles mesmos, uns - tendo permanecido na cidade - resistiram ao cerco, outros - tendo esperado a noite, a chuva e o forte vento, tendo saído da cidade e atravessado, às escondidas do exército, o cerco dos inimigos e, ainda, tendo degolado as sentinelas chegaram aqui a salvo, num estado lamentável e sem perspectivas; mas, depois de a cidade ter sido tomada à força, os que ficaram foram degolados - toda a fina flor da juventude -, as crianças e as mulheres foram reduzidas à escravidão, exceto aqueles que, tendo percebido que os Lacedemónios avançavam, se retiraram secretamente para Atenas. (104) Portanto, para os que demonstraram tâo brilhantemente a sua benevolência ao nosso povo, e para os que abandonaram todos os seus bens, filhos e esposas, observai novamente como vós lhes destes um direito parcial de cidadania. Pois, com base em vossos decretos, a lei será clara para todos, e ficareis cientes de que digo a verdade. Traze-me esse decreto e lê para eles.

\section{Decreto a respeito dos Plateenses}

Hipócrates propôs que, a partir deste dia, os Plateenses sejam cidadãos atenienses, tenham direitos cívicos como os outros Atenienses e lhes seja atribuído precisamente tudo o que é de direito dos Atenienses, tanto em matéria religiosa quanto profana, com exceção de algum sacerdócio ou culto de mistério que são transmitidos hereditariamente, e do direito de fazer parte dos nove arcontes, embora isso seja permitido a seus descendentes. Que se dividam os Plateenses em demos e tribos. E, depois que terem sido divididos, não 
mais seja permitido a nenhum dos Plateenses tornar-se Ateniense, a não ser para aquele que seja reconhecido pelo povo ateniense.

(105) Vede, Atenienses, como o orador, com nobreza e justiça, apresentou o decreto em favor do povo ateniense e exigiu que os Plateenses, ao receberem essa recompensa, passassem, primeiramente, por um exame no tribunal, para verificar se realmente eram Plateenses e amigos de nossa cidade, a fim de que, mediante esse pretexto, muitos náo obtivessem o direito de cidadania. Em seguida, que os aprovados sejam inscritos em uma estela de pedra, e que ela fique erguida na acrópole junto à deusa, a fim de que esse privilégio seja assegurado a seus descendentes e seja possível provar de quem cada qual vem a ser parente. (106) E esse decreto não permite tornar-se, mais tarde, cidadáo ateniense aquele que, presentemente, não se tenha naturalizado e nem tenha sido aprovado no tribunal: é para impedir que muitos, declarando ser Plateenses, não venham a estabelecer para si próprios o direito de cidadania. Em seguida, no decreto prescreveu-se, no interesse da cidade e dos deuses, a lei para os Plateenses e prescreveu-se, ainda, não ser permitido a nenhum deles ser sorteado entre os nove arcontes nem receber nenhum sacerdócio, embora isso seja permitido a seus descendentes, caso sejam nascidos de uma mulher ateniense, regularmente dada em casamento, conforme a lei.

(107) Não seria isso algo terrível? No que diz respeito aos nossos vizinhos que, incontestavelmente, 
se tornaram para com a cidade os mais bravos dos Gregos, vós determinastes, de modo tão justo e rigoroso, para cada um sob que condiçóes era preciso obter essa recompensa, mas essa mulher que se prostituiu publicamente em toda a Grécia, de forma tão vergonhosa e relaxada, que ultrajou a cidade e foi ímpia para com os deuses, vós a deixareis impune, ela que nem os ancestrais concederam o direito de cidadá nem o povo a tornou cidadã? (108) Na verdade, onde ela não traficou com o seu corpo, ou para onde não foi mediante salário por dia? Náo estava acompanhando em todo o Peloponeso, na Tessália e também na Magnésia, Simo de Larissa e Euridamas, filho de Medeu, em Quios e também na maior parte da Iónia, Sótades de Creta, quando fora alugada por Nicareta, porque ela ainda lhe pertencia? Portanto, o que vós pensais que fazia aquela que estava sob a dependência de outros e que acompanhava o seu pagante? Será que náo prestava todos os prazeres aos seus usuários? E depois disso, vós declarareis por um voto que uma mulher desse tipo e que é publicamente conhecida por todos, tendo trabalhado ao redor do mundo, é cidadã ateniense? (109) E que bela ação direis ter realizado aos que vos interrogarem, ou de que vergonha e impiedade vós mesmos não sereis maculados? Com efeito, antes que ela fosse acusada e participasse do litígio e todos vós fôsseis informados sobre quem ela era e como ofendeu os deuses, as faltas pertenciam a ela, mas a negligência era da cidade: alguns de vós não sabiam, mas outros, por estarem informados, indignavam-se 
pelo que era dito, mas, de fato, não sabiam o que fazer com ela, enquanto nenhum indivíduo entrasse com uma ação e não votasse sobre o caso dela. E porque também todos estais informados, tendes a mulher em vosso poder e sois soberanos para castigá-la, a partir de agora a impiedade para com os deuses torna-se vossa, caso náo a castigueis. (110) E ainda o que cada um de vós poderia dizer à própria esposa, ou à filha ou à mãe, ao entrar em casa, depois de ter absolvido essa mulher, quando uma delas vos interrogar: - "Onde estivestes?" E vós respondêsseis: - "Estávamos a julgar?” - "Quem?” - perguntar-se-á em seguida. - "Neera”, evidentemente direis (não é verdade?), "porque, sendo estrangeira, convive, contrariamente à lei, com um cidadáo, porque deu em casamento a Teógenes, o antigo rei, sua filha adúltera, que cumpriu os sacrifícios secretos em nome da cidade e foi dada como esposa a Dioniso". Além disso, depois de contardes em pormenor a acusação contra ela, direis também como ela foi acusada por cada um, com cuidado e sem esquecimento de fato algum. (111) E elas, tendo ouvido, perguntarão: "E, então, o que fizestes?” E vós respondereis: - "Absolvemo-la." Então, de hoje em diante, as mais castas das mulheres ficarão revoltadas convosco, porque julgastes aquela mulher digna de participar, do mesmo modo que elas, dos assuntos da cidade e dos ritos religiosos. Quanto às levianas, vós demonstrais claramente que elas têm a liberdade de fazer aquilo que quiserem, por vossa concessão e de vossas leis; de fato, se tolerardes isso com desprezo e displicência, parecerá que vós mesmos sois 
concordes com os costumes dela. (112) Assim, seria muito mais vantajoso que o presente processo náo se realizasse do que acontecer de vós a libertardes. Pois, de hoje em diante, as prostitutas terão completamente a liberdade de viver com quem quiserem e de afirmar que seus filhos são daqueles com quem elas se encontram ocasionalmente; por um lado, as vossas leis serão revogadas e, por outro, os hábitos das heteras serão soberanos para que realizem o que quiserem. Assim também refleti em favor das cidadãs, para que as filhas dos pobres não fiquem solteiras. (113) Com efeito, hoje em dia, se uma mulher não tem recursos, a lei dálhe um dote suficiente, mesmo se, de alguma maneira, a natureza lhe atribui uma aparência desfavorável. Mas, se a lei for ultrajada por vós, por ter sido ela absolvida, e se tiver tornado nula, a partir de agora a atividade das prostitutas estender-se-á completamente até as filhas dos cidadãos, todas aquelas que, por falta de recursos, não puderem ser dadas em casamento; por outro lado, a dignidade das mulheres livres estender-se-á até as heteras, caso obtenham o privilégio de ter filhos como quiserem e de participar tanto dos ritos de iniciação quanto dos sacrifícios e das honras da cidade. (114) Assim, para votar, que cada um de vós, em particular, pense, um no interesse da esposa, outro no interesse da filha, outro no da máe e outro no da cidade, das leis e dos ritos sagrados, a fim de que as que são honradas não se mostrem em pé de igualdade com essa prostituta, nem as que foram educadas com grande e nobre prudência e cuidado por seus pais e também as 
que foram dadas em casamento conforme as leis, estas que participam dos assuntos da cidade, mostrem-se em condiçôes iguais àquela que, com muitos e licenciosos costumes, teve relaçóes com muitos, várias vezes por dia, como cada um queria. (115) Ora, não penseis que sou eu, Apolodoro, que vos fala nem que são cidadãos aqueles que vão defendê-la ou apoiá-la, ao contrário, as leis e Neera, aqui presente, debatem uma com a outra acerca daquilo que ela fez. E quando vos encontrardes diante da acusaçáo, ouvi das próprias leis, por meio das quais a cidade é governada e pelas quais jurastes fazer o julgamento, o que elas ordenam e como eles as violaram; por outro lado, quando estiverdes diante da defesa, lembrando da acusação das leis e da prova do que foi dito, e depois de terdes visto o rosto dela, pensai somente nisto, se, sendo Neera, ela fez o que se lhe imputa.

(116) Mas vale a pena, Atenienses, pensardes neste fato: vós punistes Árquias, ${ }^{29}$ que se tornara hierofanta e fora condenado diante do tribunal por impiedade, por ter ele realizado sacrifícios contrariamente às tradiçôes; outras acusaçóes também foram apresentadas contra ele, sobretudo porque ele tinha imolado para a cortesã Sinope uma vítima que ela trouxera, nas festas em louvor de Deméter, ${ }^{30}$ junto ao altar no pátio de

${ }^{29} \mathrm{O}$ cargo de hierofanta, ou sacerdote principal do culto eleusino de Deméter, pertencia à família dos Eumólpidas, que tinha o privilégio de ter o sacerdócio e a direcçáo dos mistérios de forma hereditária.

${ }^{30}$ As festas de Haloa eram um festival de fertilidade, de colheita de frutos, em honra de Deméter, Core e, talvez, também de Dioniso. Parece que algumas cerimónias decorriam em Atenas, mas que a 
Elêusis, por não ser permitido, naquele dia, sacrificar vítimas e não ser aquele sacrifício função dele, mas da sacerdotisa. (117) Mas não seria mesmo terrível que este indivíduo, do genos dos Eumólpidas e de ancestrais de nobre nascimento e, ainda, cidadáo desta cidade, tenha recebido uma punição, porque parecia ter violado um dos ritos tradicionais? (E nem a súplica de seus pais nem a de amigos o ajudou, nem as liturgias que ele mesmo e seus ancestrais cumpriram para o bem do Estado, nem mesmo o fato de ser hierofanta, mas vós o castigastes, já que ficou decidido que ele era culpado.) E Neera, aqui presente, que cometeu um sacrilégio não só para com este mesmo deus, mas também para com as leis, ela e a filha dela, vós não as punireis?

(118) Quanto a mim, eu me pergunto, admirado, o que enfim eles vos dirão durante a defesa. Qual das duas hipóteses: que esta Neera é cidadã e está casada com ele, conforme as leis? Mas está provado que ela é uma hetera e foi escrava de Nicareta. Ou que não é esposa dele, e que ele a tem em casa como concubina? parte principal do festival consistia num rito de iniciação (telete) em Elêusis, no mês Posídeon. O festival prolongava-se durante alguns dias; durante um dia, pelo menos, era proibido oferecer sacrifícios. Os sacrifícios que eram feitos nos outros dias tinham de estar sob a jurisdição da sacerdotisa de Deméter. Os rituais femininos envolviam produtos da terra, e não sacrifícios de animais. A partir do século IV a.C., as cortesãs passaram a ter uma forte participação no festival Haloa. Esta sua participação era muito mais significativa do que em qualquer outro festival (cf. [D.] 59.116). Os sacerdotes de Elêusis preparavam um banquete no Telestério e partiam quando ele começava, deixando-o às participantes femininas, que se entregavam a uma linguagem licenciosa. A primeira parte do festival era restrita às mulheres. Os homens também eram admitidos, mas posteriormente; vd. Kapparis (1999: 413-417). 
Mas os filhos, por serem de Neera e por terem sido introduzidos na fratria por Estéfano, e sua filha, dada em casamento a um Ateniense, mostram claramente que ele a tem como esposa. (119) Como, então, não são verdadeiros os fatos denunciados e atestados? Penso que nem o próprio Estéfano nem um outro, em sua defesa, poderão demonstrar que Neera, aqui presente, é cidadã; mas eu ouvi dizer que esse tal devia alegar alguma coisa: que ele não a tem como esposa, mas como hetera e que os filhos não são dela, mas de uma outra mulher, uma cidadã, como ele, uma sua parenta, com quem casara anteriormente. (120) Pois bem, em vista da repulsa contra o argumento dele, da manobra da defesa e das testemunhas subornadas por ele, eu lhe enderecei uma intimação precisa e conforme o direito - por meio da qual vos era permitido saberdes toda a verdade: entregar-me as servas que permaneceram fielmente ligadas a Neera, Trata e Cocaline, quando ela veio de Mégara para a casa de Estéfano, e aquelas que ela adquiriu mais tarde, quando estava junto dele, Xénis e Drósis. (121) Elas sabem exatamente que Próxeno, que morreu, Aríston, que vive ainda, Antidorides, o corredor, e Fano, antes chamada Estribele, que casou com Teógenes, o antigo rei, são filhos de Neera. E caso se torne evidente, pela tortura, que Estéfano, aqui presente, casou com uma cidadã e que esses filhos são de uma outra mulher, uma cidadá, como ele, e não de Neera, eu estava disposto a abandonar este processo e náo apresentar diante do tribunal esta acusação. (122) $\mathrm{Na}$ verdade, o casamento consiste nisso: quem gera filhos, introduz os filhos 
homens entre os membros da fratria e do demo e dá as filhas em casamento aos homens, como se elas fossem suas próprias. Com efeito, as heteras nós as temos para o prazer, as concubinas para o cuidado diário do corpo, mas as esposas para que tenham filhos legítimos e mantenham a guarda fiel da casa. De tal modo que, se ele casou anteriormente com uma mulher e não com Neera, era-lhe permitido, por meio do testemunho mais seguro, provar isso, ao entregar as mencionadas servas. (123) Como prova de que o citei, o escrivão lerá para vós o testemunho desses fatos e também a intimação. Lê o testemunho, em seguida, a intimação.

\section{Testemunho}

Hipócrates, filho de Hipócrates, do demo de Probalinto, Demóstenes, filho de Demóstenes, do demo de Peânia, Diófanes, filho de Diófanes, do demo de Alópece, Dinómenes, filho de Arquelau, do demo de Cidateneu, Dínias, filho de Formo, do demo de Cidantidas, Lisímaco, filho de Lisipo, do demo de Egília, testemunham que estavam presentes na ágora quando Apolodoro citava Estéfano e exigia que ele entregasse as servas para tortura, para verificar os pontos acerca dos quais Apolodoro acusava Estéfano a respeito de Neera. Testemunham que Estéfano não quis entregar as servas e que a intimação é esta que Apolodoro apresenta.

(124) Pois bem, lê a própria intimação que eu enderecei a este Estéfano, aqui presente. 


\section{Intimaçáo}

Assim, Apolodoro intimou Estéfano a respeito da acusação que ele intentou contra Neera de ser ela a esposa de um cidadão ateniense, sendo estrangeira; está ele disposto a receber as servas de Neera, que ela trouxera de Mégara, Trata e Cocaline, e aquelas que ela adquiriu mais tarde, ao lado de Estéfano, Xénis e Drósis, as quais estão perfeitamente informadas a respeito dos filhos que são de Neera, mas não são de Estéfano: Próxeno, que morreu, Aríston, que vive ainda, Antidorides, o corredor, e Fano, sob a condição se serem elas submetidas à tortura. Por um lado, se elas confessarem que essas crianças são filhos de Estéfano e de Neera, que esta mulher seja vendida conforme as leis, e seus filhos sejam considerados estrangeiros; mas, se não confessarem que eles são dela, mas de outra mulher, uma cidadá, eu estava disposto a abandonar o processo de Neera e a pagar os danos que elas sofressem, caso fossem prejudicadas por causa da tortura. ${ }^{31}$

(125) Juízes, embora eu tenha encaminhado a

${ }^{31} \mathrm{O}$ exame de testemunhas que fossem escravas apenas era realizado sob tortura. Era bem provável que qualquer escravo examinado ficasse fisicamente afetado, a náo ser que concordasse com aquilo que o seu interrogador queria que ele dissesse. Sabe-se que não havia limites à extensão da tortura permitida, embora a morte do escravo levasse o atormentador a julgamento por homicídio, acusação que seria conduzida pelo proprietário do escravo. Há notícia de uma situação semelhante em Demóstenes, Contra Panténeto, D. 37.40, cf. MacDowell (1966: 20-21, 94-100, 126-127). 
intimação a este Estéfano, aqui presente, ele não quis aceitá-la. Por conseguinte, juízes, não vos parece que o processo foi julgado pelo próprio Estéfano aqui, no sentido de que Neera está submetida à acusação que eu intentei contra ela, no sentido de que eu vos disse a verdade e apresentei os testemunhos verdadeiros, e que este homem vos enganará completamente com o que disser e demonstrará a sua falsidade por se ter recusado a entregar as servas que eu lhe exigia?

(126) Portanto, juízes, para vingar a mim mesmo e aos deuses, em relação aos quais eles cometeram sacrilégio, eu entrei em litígio contra estes aqui presentes e trouxe-os perante o vosso julgamento. Além disso, é preciso que vós, ao julgardes, não vos esqueçais dos deuses, que eles ultrajaram, e do voto que cada um de vós declarar; é preciso votar conforme as prescriçôes legais e vingar, antes de tudo, os deuses e, em seguida, vós mesmos. E depois de terdes feito isso, parecerá a todos que julgastes com retidão e justiça essa ação pública que eu intentei contra Neera, porque, sendo estrangeira, casou com um cidadáo. 


\section{BibLIOGRAFia}

\section{Ediçóes, Comentários E Traduçóes}

Carey, Christopher, ed. (1992). Apollodoros. Against Neaira [Demosthenes] 59. Warminster: Aris \& Phillips.

Colubi Falcó, José Manuel (1983). Demóstenes, Discursos Privados II. Introduções, tradução e notas. Madrid: Editorial Gredos.

Gernet, Louis (2002, 2éd.). Démosthène. Plaidoyers Civils. Tomo IV (Discours LVII-LIX). Texto estabelecido e traduzido. Índice por J.A. de Foucault e R. Weil. Paris: Les Belles Lettres.

Kapparis, Konstantinos A., ed. (1999). Apollodoros. Against Neaira [D. 59]. Berlin: Walter de Gruyter.

Rennie, W. (1931, reimp. 1991). Demosthenis Orationes. Tomo III. Oxford.

\section{Estudos}

Carawan, Edwin, ed. (2007). The Attic Orators. Oxford: Oxford University Press.

CAREy, Christopher (1997). Trials from Classical Athens. London: Routledge.

Carlier, Pierre (1990). Démosthène. Paris: Fayard.

Christ, R. Matthew (1998). The Litigious Athenian. Baltimore: The Johns Hopkins University Press. 
Cortés Gabaudán, F. (1986). Formulas Retoricas de la Oratoria Judicial Atica. Salamanca: Ediciones Universidad de Salamanca.

Cox, Cheryl Anne (1998). Household Interests: Property, Marriage Strategies, and Family Dynamics in Ancient Athens. Princeton: Princeton University Press.

Curado, Ana Lúcia (2008). Mulheres em Atenas. As Mulheres Legitimas e as Outras. Lisboa: Sá da Costa Editora.

Davidson, James (1998). Courtesans and Fishcakes. The Consuming Passions of Classical Athens. London: Fontana Press.

Edwards, Michael (1994). The Attic Orators. London: Bristol Classical Press.

Freeman, Kathleen (1946). The Murder of Herodes and Other Trials from the Athenian Law Courts. London: MacDonald \& Co.

Hamel, Debra (2003). Trying Neaira. The True Story of a Courtesan's Scandalous Life in Ancient Greece. New Haven: Yale University Press.

Harrison, A. R. W. (1931, reimp. 1998). The Law of Athens. Prefácio de D. M. MacDowell. 2 vols. London: Bristol Classical Press.

Hunter, Virginia (1994). Policing Athens: Social Control in the Attic Lawsuits, 420-320 B.C. Princeton: 


\section{Princeton University Press.}

—- Virginia e Edmondson, Jonathan, eds. (2000). Law and Social Status in Classical Athens. Oxford: Oxford University Press.

Jaeger, W. (1945). Demóstenes. La agonía de Grecia. México: Fondo de Cultura Económica.

Just, Roger (1989). Women in Athenian Law and Life. London: Routledge.

Kennedy, George (1963). The Art of Persuasion in Greece. Princeton: Princeton University Press.

Keuls, Eva V. (1993). The Reign of the Phallus. Sexual Politics in Ancient Athens. Berkeley: University of California Press.

Lacey, W. K. (1968). The Family in Classical Greece. London: Thames and Hudson.

Lanni, Adriaan (2008). Law and Justice in the Courts of Classical Athens. New York NY: Cambridge University Press.

Macdowell, Douglas M. (1966). Athenian Homicide Law in the Age of the Orators. Manchester University Press.

- D. M. (1978). The Law in Classical Athens. London: Thames \& Hudson.

Macurdy, G. H. (1942). «Apollodorus and the Speech against Neaera (Pseudo-Dem. LIX)», American 
Journal of Philology, 63, pp. 257-271.

Mossé, Claude (1983). La femme dans la Grèce antique. Paris: Albin Michel.

—_ Claude (1994). Démosthène ou les Ambiguïtés de la Politique. Paris: Armand Colin.

Patterson, Cynthia B. (1998). The Family in Greek History. Cambridge MA: Harvard University Press.

Pearson, L. (1966). «Apollodorus, the eleventh Attic Orator", in L. Wallach, ed., The Classical Tradition, Literary and Historical Studies in Honor of Harry Caplan. Ithaca NY: Cornell University Press, pp. 347-359.

Pomeroy, Sarah B. (1997). Families in Classical and Hellenistic Greece. Representation and Realities. Oxford: Clarendon Press.

Rubinstein, Lene (2000). Litigation and Cooperation: Supporting Speakers in the Courts of Classical Athens. Historia Einzelschriften 147. Stuttgart: Steiner.

Todd, S. C. (1995). The Shape of Athenian Law. Oxford: Clarendon Press.

Trevett, Jeremy (1992). Apollodoros. The Son of Pasion. Oxford: Clarendon Press.

Usher, S. (1999). Greek Oratory. Tradition and Originality. Oxford: Oxford University Press. 
Whitehead, David (2006). «The Mysterious 'Cyreneans' in [Demosthenes] 59.9.» The Classical Quarterly NS, 56: 1, pp. 317-321.

Worthington, I., ed. (1994). Persuasion: Greek Rhetoric in Action. London: Routledge. 
(Página deixada propositadamente em branco) 


\section{ÍNDICE DE NOMES}

ACARnAS: $45,47$.

Afidna: 9, 43.

Alcístenes: arconte, 36.

Alópece: demo da tribo Antioquide, 25, 45, 47, 123.

Andros: ilha do Egeu, 64, 71.

Anfictiấ: 98.

ÂNiTO: de Lacíadas, 61.

Anteia: escrava, 19.

ANTESTÉRION: 76.

ANTIDORIDEs: filho de Neera, 121, 124.

Apolo: Pátrio, 97.

Apolodoro: filho de Pásion, 2-5, 7, 10, 11, 14, 47, 71, 115, 123, 124.

Apolófanes: ateniense, 10.

Apolónides: olíntio, 91.

Areópago: 80, 81, 83.

Argivos: 101.

ARIstocleia: escrava, 19.

Aristócrates: de Falero, 40.

Aristómaco: de Céfalas, 65, 71.

Aríston: filho de Neera, 38, 121, 124.

Arquelau: pai de Dinómenes, 123.

ÁrQUias: hierofanta, 116.

Arquidamo: rei de Esparta, 98.

Artemísio: 95.

Asopo: rio da Beócia, 99.

Asteios: arconte, 35, 36.

Assembleia: 4, 27, 89.

Atenas: 25, 32, 35, 64, 85, 103.

Atenienses: 1, 2, 16, 24, 28, 73, 74, 77, 80, 88, 89, 90, 94, 100, 102, 104, 105, 116.

Atmonia: demo da tribo Cecrópida, 28.

BÁRBAROS: 97.

Beócios: 94, 95, 101.

Braquilo: sogro de Lísias, 22.

Brítidas: 59, 61.

CÁbrias: do demo ático de Exone 33, 34.

Calístrato: 27, 43.

Carísio: 18.

CÉfalas: demo da tribo Acamântide, 61, 71. 
Céfalo: pai de Lísias, 23.

Cefísia: demo da tribo de Erecteu, 40.

Cefisofonte: 10.

CÉrames: demo da tribo Acamântide, 48.

Cidantidas: demo da tribo Egeide, 24, 123.

Cidateneu: demo da tribo Pandionide, 34, 123.

Ciríade: demo da tribo Hipotôntide, 40.

Ciros: ilha do Egeu, 4.

Clinómaco: 39.

Cocaline: escrava, 35, 120, 124.

Colias: promontório de, 33, 34 .

Colono: demo, 22, 23.

Conselho: 3, 4, 27, 80, 81, 83.

Coríntio: 29, 32.

Corinto: 23, 26, 28, 30, 32, 36.

Corónides: demo, 72.

Critodemo: pai de Aristómaco, 25.

Ctesipo: de Cidantidas, 24, 25.

Ctéson: de Cérames, 48.

Dario: rei da Pérsia, 94.

DÁtıs: general do rei Dario, 94.

Delfos: 33, 97.

Demócares: filho de Démon, 30, 32, 40.

DÉmon: pai de Demócares, 30.

Demóstenes: orador, 123; pai do orador, 123.

Dífilo: de Mélite, 58.

Dínias: de Cidantidas, 123.

Dinómenes: de Cidateneu, 123.

Diófanes: filho de Diófanes, de Alópece, 123; pai do anterior, 123.

Diogíton: de Acarnas, 45, 47.

Dioniso: 73, 76, 110; filho de Filóstrato, 23.

Diopites: de Mélite, 48.

Doroteu: de Elêusis, 59.

Drósis: escrava, 120, 124.

Eetes: de Ciríade, 40.

Egília: demo da tribo Antioquide, 50, 54, 61, 123.

ElêusIs: demo da tribo Hipotôntide, 116.

ÉLIS: 18

ENIANES: 101.

EpÉneto: de Andros, 64, 66-71.

ERÉADAs: demo da tribo Hipotôntide, 40, 61. 
ERÉTRIA: 94.

Érquia: demo da tribo Egeide, 84.

ESPÍNTARO: 39.

EstÉFAnO: de Eréadas, 1, 5, 10, 11, 13-16, 27, 28, 37, 39-43, 47-54, 56, 62-64, 66-69, 71, 72, 79, 81-84, 88, 93, 118-121, 123-125.

Estrátocla: escrava, 19.

Estribele (Fano): filha de Neera, 50, 121.

Eteus: 101.

Eubeia: 4.

Eubulo: de Probalinto, 48.

Êucrates: de Lêucade, 29-32, 36.

Eufileto: de Exone, 25.

EUfranor: de Egília, 61.

Euridamante: filho de Medeu, 108.

Eurímaco: filho de Leoncíades, 99.

Eutetíon: de Cidateneu, 34.

Evalces: de Falero, 61.

Exone: demo da tribo Cecrópidas, 25, 33.

Falero: demo da tribo Eântides, 40, 61.

FANO (Estribele): filha de Neera, 38, 50, 71, 84, 121, 124.

Fila: escrava, 19.

Filagro: de Mélite, 32.

Filipe: de Macedónia, 3.

Filóstrato: de Colono, 22, 23.

FoCENSES: 101.

Formo: pai de Dínias, 123.

Frasiclides: arconte, 37.

Frastor: de Egília, 50-56, 58-63, 69.

Frínion: de Peânia, 30-35, 37, 38, 40, 45-49.

GLÁucetes: de Cefísia, 40.

Glauconides: pai de Ctesipo, 24, 25.

Gregos: 94, 97, 98, 107.

Hécale: demo da tribo Leontide, 61.

HÉlADE: 95, 96, 107.

Hermes: 39.

Hiparco: ator, 26, 28.

HípIAs: cozinheiro, 16.

Hipócrates: de Probalinto, 123; pai do anterior, 123.

IMBros: ilha do mar trácio, 4.

IOBACCHEIA: 78.

IÓNIA: 108. 
IsTMÍADA: escrava, 19.

LACEDEMÓNIO: irmão de Sátiro, 45.

LACEDEMónios: 27, 35, 36, 37, 95, 96, 98, 101, 102, 103.

LACíADAS: demo da tribo Eneide, 61.

LAMPTRAS: demo da tribo Erecteide, 45, 47.

LARISSA: cidade da Tessália, 108.

Lemnos: ilha do mar trácio, 3.

LEÓNIDAS: rei de Esparta, 95

LeONCÍAdes: pai de Eurímaco, tebano, 99.

LEUCÁdio: 29, 32.

Leuctros: batalha de ..., 37.

LimNAS: 76.

Lísias: logógrafo, 21-23.

Lisímaco: de Egília, 123.

Lisipo: pai de Lisímaco, 123.

LOCRENSES: 101.

MAGNÉSIA: 108.

MaLianos: 101.

Maratona: 94.

Mardónio: general da Pérsia, 96.

Medeu: pai de Euridamante, 108.

Medos: 95, 97.

MÉGara: 35-38, 49, 124.

Megarenses: 36.

Mélite: demo da tribo Cecrópidas, 32, 48, 58.

Metanira: escrava, 19, 21-23.

Mítis: argivo, 33.

Nauclides: de Plateias, 99.

Nausífilo: filho de Nausinico, 65, 71.

NAUSINICO: arconte, 65.

NeEra: hetera, 1, 14, 16, 17, 19, 20, 22-25, 28, 32, 34, 40, 42-49, 51, 54-56, 59, 61-65, 67, 69, 70, 72, 81-83, 110, 115, 117-126.

NiCARETA: liberta, 18, 20-25, 29, 108, 118.

Nicipo: de Céfalas, 61, 71.

ODÉON: 52, 54.

OLíntio: 91.

Olinto: cidade da Calcídica, 4.

PALÁdio: 9.

PÁSION: 2.

PausÂnias: rei de Esparta, 96, 97.

PeÂnia: demo da tribo Pandionide, 30, 123. 
Peloponeso: 108.

Píticos: Jogos, 33.

Pítolas: tessálio, 91.

Plateenses: 94, 95, 98, 100, 101, 102, 103, 104, 105, 106.

Plateias: batalha de ..., 96, 97, 100, 101.

Probalinto: demo da tribo Pandionide, 48, 123.

Próxeno: filho de Neera, 38, 121, 124.

Quersoneso: 4.

Quios: ilha do Egeu, 108.

Quiónides: de Xipete, 34.

SALAMINA: 95, 97.

SÁtiro: de Mélite, 58.

SÁURIAS: de Lamptras, 45, 47.

Simo: tessálio, 24, 25, 108.

Símon: pai de Eufileto, 25.

SINOPE: hetera, 116.

SOCRATIDES: arconte, 33.

SótADEs: cretense, 108.

Tebanos: 37, 95, 100, 101.

Tebas: 99.

Teógenes: arconte rei, 72, 79-81, 83, 84, 110, 121.

Teomnesto: cunhado de Apolodoro: 16.

TERMÓPILAS: 95.

Tessália: 108.

Tessálio: 24, 25, 91.

Teseu: 75.

THEOINIA: 78.

TIMANÓRIDAS: coríntio, 29-32, 36.

Timóstrato: de Hécale, 61.

Trata: escrava, 35, 120, 124.

Xantipo: de Eréadas, 61.

XÉNIS: escrava, 120, 124.

Xenoclides: poeta, 26, 28.

XerXes: 95.

Xipete: demo da tribo Cecrópidas, 34.

Zeuxidamo: pai de Arquidamo, 98. 


\section{Volumes publicados na ColecÇÃo Autores Gregos e Latinos - Série Textos Gregos}

1. Delfim F. Leão e Maria do Céu Fialho: Plutarco. Vidas Paralelas - Teseu e Rómulo. Tradução do grego, introdução e notas (Coimbra, CECH, 2008).

2. Delfim F. Leão: Plutarco. Obras Morais - O banquete dos Sete Sábios. Tradução do grego, introdução e notas (Coimbra, CECH, 2008).

3. Ana Elias Pinheiro: Xenofonte. Banquete, Apologia de Sócrates. Tradução do grego, introdução e notas (Coimbra, CECH, 2008).

4. Carlos de Jesus, José Luís Brandão, Martinho Soares, Rodolfo Lopes: Plutarco. Obras Morais - No Banquete I-Livros I-IV. Tradução do grego, introdução e notas. Coordenação de José Ribeiro Ferreira (Coimbra, $\mathrm{CECH}, 2008)$.

5. Ália Rodrigues, Ana Elias Pinheiro, Ândrea Seiça, Carlos de Jesus, José Ribeiro Ferreira: Plutarco. Obras Morais - No Banquete II - Livros V-IX. Tradução do grego, introdução e notas. Coordenação de José Ribeiro Ferreira (Coimbra, CECH, 2008).

6. Joaquim Pinheiro: Plutarco. Obras Morais - Da Educação das Crianças. Tradução do grego, introdução e notas (Coimbra, CECH, 2008).

7. Ana Elias Pinheiro: Xenofonte. Memoráveis. Tradução do grego, introdução e notas (Coimbra, $\mathrm{CECH}, 2009)$. 
8. Carlos de Jesus: Plutarco. Diálogo sobre o Amor, Relatos de Amor. Tradução do grego, introdução e notas (Coimbra, CECH, 2009).

9. Ana Maria Guedes Ferreira e Ália Rosa Conceição Rodrigues: Plutarco. Vidas Paralelas - Péricles e Fábio Máximo. Tradução do grego, introdução e notas (Coimbra, CECH, 2010).

10. Paula Barata Dias: Plutarco. Obras Morais - Como Distinguir um Adulador de um Amigo, Como Retirar Benefício dos Inimigos, Acerca do Número Excessivo de Amigos. Tradução do grego, introdução e notas (Coimbra, CECH, 2010).

11. Bernardo Mota: Plutarco. Obras Morais - Sobre a Face Visivel no Orbe da Lua. Tradução do grego, introdução e notas (Coimbra, CECH, 2010).

12. J. A. Segurado e Campos: Licurgo. Oração Contra Leócrates. Tradução do grego, introdução e notas (Coimbra, CECH /CEC, 2010).

13. Carmen Soares e Roosevelt Rocha: Plutarco. Obras Morais - Sobre o Afecto aos Filhos, Sobre a Música. Tradução do grego, introdução e notas (Coimbra, $\mathrm{CECH}, 2010)$.

14. José Luís Lopes Brandão: Plutarco. Vidas de Galba e Otão. Tradução do grego, introdução e notas (Coimbra, CECH, 2010). 
15. Marta Várzeas: Plutarco. Vidas Paralelas - Demóstenes e Cícero. Tradução do grego, introdução e notas (Coimbra, CECH, 2010).

16. Maria do Céu Fialho e Nuno Simões Rodrigues: Plutarco. Vidas Paralelas - Alcibiades e Coriolano. Tradução do grego, introdução e notas (Coimbra, $\mathrm{CECH}, 2010)$.

17. Glória Onelley e Ana Lúcia Curado: Apolodoro. Contra Neera. [Demóstenes] 59. Tradução do grego, introdução e notas (Coimbra, CECH, 2011). 
(Página deixada propositadamente em branco) 
OBRA PUBLICADA

COM A COORDENAÇÃO

CIENTÍFICA

O

TT Centro de Estudos

11 Clássicos e Humanisticos

- $\mathrm{U}$

C - 